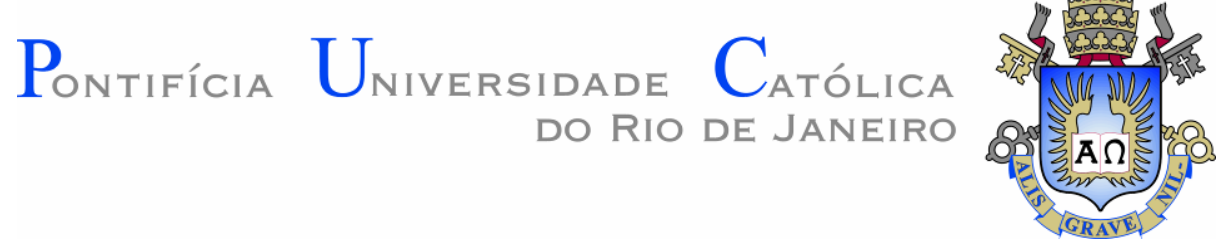

Daiana Santos Eringer

Estudo experimental do comportamento de pilares mistos com perfis de aço de alta resistência

Dissertação de Mestrado

Dissertação apresentada como requisito parcial para obtenção do grau de Mestre pelo Programa de PósGraduação em Engenharia Civil do Departamento de Engenharia Civil da PUC-Rio.

Orientador: Prof. Sebastião Arthur Lopes de Andrade

Rio de Janeiro

Março de 2017 


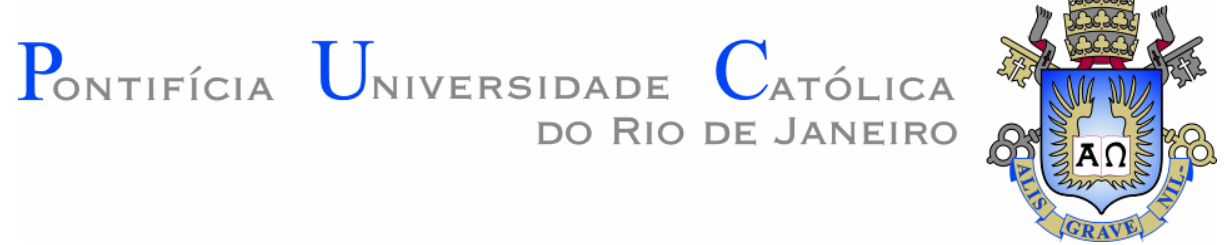

Daiana Santos Eringer

\section{Estudo experimental do comportamento de pilares mistos com perfis de aço de alta resistência}

Dissertação apresentada como requisito parcial para obtenção do grau de Mestre pelo Programa de Pós-Graduação em Engenharia Civil do Departamento de Engenharia Civil do Centro Técnico Científico da PUC-Rio. Aprovada pela Comissão Examinadora abaixo assinada.

Prof Sebastião Arthur Lopes de Andrade Orientador

Departamento de Engenharia Civil - PUC-Rio

Prof. Julio Jerônimo Holtz Departamento de Engenharia Civil - PUC-Rio

Prof. José Guilherme Santos da Silva Universidade do Estado do Rio de Janeiro UERJ

Prof. Marcio da Silveira Carvalho Coordenador Setorial do Centro Técnico Científico - PUC-Rio

Rio de Janeiro, 22 de março de 2017 
Todos os direitos reservados. É proibida a reprodução total ou parcial do trabalho sem autorização da universidade, do autor e do orientador.

\section{Daiana Santos Eringer}

Graduada em Engenharia Civil pela Universidade Federal Fluminense - UFF em 2014. Principais áreas de interesse: Estruturas de aço e mistas.

Ficha Catalográfica

Eringer, Daiana Santos

Estudo experimental do comportamento de pilares mistos com perfis de aço de alta resistência / Daiana Santos Eringer; Orientador: Sebastião Arthur Lopes de Andrade - Rio de Janeiro: PUC - Rio, Departamento de Engenharia Civil, 2017.

$79 \mathrm{f}$. il; $29,7 \mathrm{~cm}$.

Dissertação de Mestrado em Engenharia Civil Pontifícia Universidade Católica do Rio de Janeiro, Rio de Janeiro, 2017.

Inclui referências bibliográficas.

1. Engenharia civil - Teses. 2. Estruturas de aço. 3. Análise experimental de estruturas. 4. Pilares mistos I. Andrade, Sebastião Arthur Lopes II. Pontifícia Universidade Católica do Rio de Janeiro. Departamento de Engenharia Civil. III. Título. 
Ao meu avô Ivalcy, E ao meu amor, João Paulo. 


\section{Agradecimentos}

Primeiramente agradeço a Deus que nunca me desampara e sempre me indica o caminho certo a seguir.

Ao meu marido, meu maior incentivador e meu porto seguro, obrigada por encarar mais esse desafio ao meu lado.

Aos meus pais, Maria Alexandrina e Evaldo, que sempre incentivaram e financiaram meus estudos. E aos meus irmãos que fazem com que me esforce cada vez mais para servir de exemplo.

Aos meus amigos e familiares que entenderam, ou apenas aceitaram, a minha ausência em vários momentos.

Aos alunos da graduação, chamados carinhosamente de Minions, João, Daniel, Matheus e Rafael, que dividiram comigo toda a parte experimental desta pesquisa, foram por muitas vezes meus "braços fortes", sem eles não teria conseguido.

Aos técnicos do laboratório de estruturas e materiais da PUC-Rio, em especial ao Rogério, ao Euclides e ao José Nilson, sem os quais nenhum experimento seria possível.

Aos amigos da PUC-Rio. Especialmente à Ana, à Rebecca e à Letícia, por tornar essa jornada mais leve ao dividir os desafios e as conquistas. À Bárbara por fazer o trajeto Niterói - Gávea menos exaustivo. Aos amigos do bandejão e do café que proporcionaram muitas discussões e gargalhadas neste último ano, e aos que ajudaram de alguma forma ao longo desses dois anos. A todos eles muito obrigada.

Ao meu professor e orientador, Sebastião por todo o conhecimento transmitido e por tornar esta pesquisa possível.

A todos os professores e funcionários que de alguma forma contribuíram nestes dois anos de mestrado. À professora Deane pelo apoio, e à secretária Rita por todas as informações e auxílios.

Ao CNPq pelo suporte financeiro para a realização desta pesquisa. 


\section{Resumo}

Eringer, Daiana Santos; Andrade, Sebastião Arthur Lopes (Orientador). Estudo experimental do comportamento de pilares mistos com perfis de aço de alta resistência. Rio de Janeiro, 2017. 79p. Dissertação de Mestrado - Departamento de Engenharia Civil, Pontifícia Universidade Católica do Rio de Janeiro.

Estruturas mistas de aço e concreto estão se tornando cada vez mais viáveis do ponto de vista de execução com custos mais competitivos. Graças às pesquisas e aos estudos desenvolvidos que visam aproveitar ao máximo as vantagens oferecidas pelos materiais concreto e aço, as estruturas mistas vêm sendo cada vez mais utilizadas na construção civil. Neste estudo são apresentadas as configurações estruturais dos pilares mistos e recomendações de projeto de normas vigentes. $\mathrm{O}$ objetivo dessa dissertação é avaliar o comportamento experimental de pilares mistos com perfis de aço de alta resistência submetidos a ensaios em escala real. Para tal avaliação, levou-se em consideração as características e propriedades dos materiais que compõem as peças: concreto, aço das armaduras e aço de alta resistência dos perfis de chapa dobrada. Para atingir o objetivo deste trabalho, foram testados seis elementos mistos com seção transversal formada por dois perfis $U$ de chapa dobrada e concreto armado, formando uma seção retangular. Inicialmente duas colunas foram submetidas à compressão centrada e duas vigas foram testadas à flexão. Posteriormente os dois pilares mistos foram ensaiados com excentricidade de $40 \mathrm{~mm}$ no carregamento. Os resultados experimentais foram, então, analisados e comparados com os resultados teóricos calculados com as recomendações da norma brasileira ABNT NBR 8800:2008 e do Eurocode 4, 2004. E os resultados experimentais foram em média coerentes com os teóricos calculados.

\section{Palavras-chave}

Estruturas de aço; análise experimental de estruturas; pilares mistos. 


\section{Abstract}

Eringer, Daiana Santos; Andrade, Sebastião Arthur Lopes (Advisor). Experimental study of composite beam-columns with high strength steel sections. Rio de Janeiro, 2017. 79p. Dissertação de Mestrado - Departamento de Engenharia Civil, Pontifícia Universidade Católica do Rio de Janeiro.

Composite structures of steel and concrete are becoming increasingly feasible from the execution point of view, with more competitive costs. Thanks to the work and studies developed that aim to make the most of the advantages offered by both materials, they have been increasingly used in building construction. This study presents the structural configurations of the composite beam-columns and design recommendations using current codes. The objective of this dissertation is to evaluate the experimental behavior of composite beam-columns with high strength steel profiles tested in real scale specimens. For this analysis, the characteristics and properties of the materials that compose the structure were taken into consideration: concrete, reinforcing steel and high strength steel of the cold formed sections. To reach the aims of this work, six composite elements with cross section formed by two channel profiles of folded sheet and reinforced concrete were tested. Initially two columns were subjected to centered compression and two beams were subjected to flexural tests. Subsequently, the composite beam-columns were tested with a $40 \mathrm{~mm}$ eccentricity at loading. The experimental results were then analyzed and compared with the theoretical ones, which were calculated with the recommendations of the Brazilian standard ABNT NBR 8800:2008 and the Eurocode 4, 2004. The experimental results, obtained were consistent with the theoretical predictions.

\section{Keywords}

Steel-Structures; Experimental Analysis; Composite beam-columns 


\section{Sumário}

1 Introdução 15

1.1. Considerações iniciais 15

1.2. Objetivos 16

1.3. Revisão bibliográfica 16

1.4. Organização da Dissertação 18

2 Projeto de pilares mistos $\quad 20$

2.1. Estruturas mistas de aço e concreto 20

2.2. Pilares Mistos: tipos e aplicações 21

2.3. Fatores que influenciam na resistência do pilar misto 22

2.3.1. Aderência entre aço e concreto 23

2.3.2. Efeito do confinamento do concreto 24

2.3.3. Propriedades do concreto 25

2.3.4. Outros fatores 25

2.4. Dimensionamento segundo as normas técnicas 25

2.4.1. Norma brasileira 26

2.4.2. Eurocode 28

3 Programa experimental 32

3.1. Considerações gerais 32

3.2. Processo de construção 34

3.3. Propriedades dos materiais $\quad 35$

3.3.1. Concreto 36

3.3.2. Aço das armaduras 37

3.3.3. Aço do Perfil 37

3.4. Descrição dos ensaios 39

3.4.1. Ensaios de compressão 39

3.4.2. Ensaios de flexão $\quad 41$

3.4.3. Ensaios de flexo-compressão 43

4 Resultados experimentais $\quad 45$

4.1. Considerações iniciais 45 
4.2. Ensaios de compressão 45

4.3. Ensaios de flexão 50

4.4. Ensaios de flexo-compressão 52

5 Análise de resultados $\quad 58$

5.1. Considerações iniciais 58

5.2. Colunas 58

5.3. Vigas $\quad 59$

$\begin{array}{ll}\text { 5.4. Pilares } & 60\end{array}$

6 Considerações finais 64

6.1. Conclusões 64

6.2. Sugestões para trabalhos futuros 65

$\begin{array}{llr}7 & \text { Referências bibliográficas } & 67\end{array}$

8 Apêndice A $\quad 71$

9 Apêndice B $\quad 74$

10 Apêndice C $\quad 76$ 


\section{Lista de figuras}

Figura 2.1 - Seções transversais típicas de pilares mistos (Eurocode 4, 2004).

Figura 2.2 - Curva de interação para combinação de compressão e momento uniaxial (Eurocode 4, 2004).

Figura 2.3 - Curva de interação simplificada e distribuições de tensões correspondentes (Eurocode 4, 2004).

Figura 3.1 - Treliça formada de perfis de chapa fina. 33

Figura 3.2 - Seção transversal das peças, dimensões em mm.

Figura 3.3 - Seções transversais dos perfis de aço de alta resistência, (a) seção sem enrijecedor e (b) seção com o enrijecedor (dimensões em mm).

Figura 3.4 - Foto da ligação da treliça para mostrar descontinuidade da seção do perfil. (DALTRO, 2016)

Figura 3.5 - Forma e armadura prontas para a concretagem. 35

Figura 3.6 - Ensaio de compressão de corpo de prova de concreto. 36

Figura 3.7 - Gráfico de tensão versus deformação dos ensaios de caracterização do aço. (DALTRO, 2016).

Figura 3.8 - Instrumentação com transdutores de deslocamento na seção central da coluna.

Figura 3.9- Posição dos transdutores na seção central da peça, dimensões em $\mathrm{mm}$.

Figura 3.10 - Ensaio de compressão axial.

Figura 3.11 - Apoios dos ensaios das vigas.

Figura 3.12 - Representação do carregamento das vigas e suas respectivas distâncias em mm.

Figura 3.13 - Sistema dos ensaios 3 e 4 com viga auxiliar para carregamento em dois pontos.

Figura 3.14 - Ensaio com excentricidade no carregamento

Figura 4.1 - Gráfico força normal aplicada x deslocamento lateral, transdutores TD02 e TD04, da Coluna 01.

Figura 4.2 - Gráfico força normal aplicada x deslocamento lateral, transdutores TD01 e TD03, da Coluna 01. 
Figura 4.4 - Apoio da Coluna 01 antes e após o ensaio.

Figura 4.5 - Gráfico força normal aplicada x deslocamento lateral, TD02 e TD04, da Coluna 02.

Figura 4.6 - Gráfico força normal aplicada x deslocamento lateral, TD01 e TD03, da Coluna 02.

Figura 4.7 - Coluna 02 ensaiada.

Figura 4.8 - Gráfico momento aplicado x deslocamento no centro do vão das Viga 01 e Viga 02.

Figura 4.9 - Viga 01 durante o ensaio.

Figura 4.10 - Posição dos transdutores na seção central do pilar e do ponto de aplicação de carga em relação aos eixos da peça.

Figura 4.11 - Pilar 01 após o ensaio de compressão excêntrica. 53

Figura 4.12 - Gráfico força normal aplicada x deslocamento lateral, transdutores TD02 e TD04, Pilar 01.

Figura 4.13 - Gráfico força normal aplicada x deslocamento lateral, transdutores TD01 e TD03, do Pilar 01. 54

Figura 4.14 - Detalhe da ruptura do concreto do Pilar 02.

Figura 4.15 - Pilar 02 após o ensaio. 56

Figura 4.16 - Gráfico força normal aplicada x deslocamento lateral, TD02 e TD04, do Pilar 02.

Figura 4.17- Gráfico força normal aplicada x deslocamento lateral, TD01 e TD03, do Pilar 02.

Figura 5.1- Curva de interação simplificada de acordo com o Euroode 4, 2004 e resultados experimentais representados por triângulos.

Figura 5.2 - Gráfico Força normal resistente versus espessura da chapa do perfil.

Figura A. 1 - Forças internas e deformações da seção submetida à flexão.

Figura B. 1 - Forças internas e externa da seção submetida à flexo-compressão. 74

Figura C. 1 - Seção transversal e dimensões consideradas. 


\section{Lista de tabelas}

Tabela 1 - Panorama de alguns dos trabalhos realizados sobre pilares mistos (Adaptada de FABRIZZI, 2009 e KENNEDY \& MacGREGOR, 1984) Parte I.

Tabela 2 - Panorama de alguns dos trabalhos realizados sobre pilares mistos (Adaptada de FABRIZZI, 2009 e KENNEDY \& MacGREGOR, 1984) Parte II.

Tabela 3 - Resistência limite de cisalhamento entre o aço e o concreto

( $\boldsymbol{\tau R d}$ ) para dispensa do uso de conectores em MPa.

Tabela 5 - Resultados dos ensaios de tração do aço das armaduras longitudinais, aço CA-50.

Tabela 6 - Resultados dos ensaios de caracterização do aço do perfil (DALTRO, 2016).

Tabela 6 - Comparação entre a normal prevista e a normal experimental.

Tabela 7 - Comparação da estimativa pelos ensaios de flexão e pelo valor teórico à flexão, apêndice $\mathrm{A}$, com os ensaios de flexo-compressão. 


\section{Lista de Símbolos}

a Comprimento da alma do perfil;

$A_{a} \quad$ Área da seção transversal do perfil de aço;

$A_{c} \quad$ Área da seção transversal do concreto;

$A_{s} \quad$ Área da seção transversal da armadura tracionada;

$A_{S}^{\prime} \quad$ Área da seção transversal da armadura tracionada;

b Largura da seção transversal;

$b_{e f} \quad$ Largura efetiva;

$b_{n} \quad$ Largura da linha neutra plástica;

d Distância do centroide da armadura à face da seção;

$\delta \quad$ Fator de contribuição do aço;

$e \quad$ Excentricidade de carregamento;

$E_{a} \quad$ Módulo de elasticidade do aço estrutural;

$E_{c} \quad$ Módulo de elasticidade do concreto;

$E_{c, \text { red }} \quad$ Módulo de elasticidade reduzido do concreto;

$E_{S} \quad$ Módulo de elasticidade do aço da armadura;

$(E I)_{e} \quad$ Rigidez efetiva à flexão;

$\varepsilon_{c} \quad$ Deformação específica do concreto;

$\varepsilon_{c h c} \quad$ Deformação específica do aço do perfil comprimido;

$\varepsilon_{c h T}$ Deformação específica do aço do perfil tracionado;

$\varepsilon_{s} \quad$ Deformação específica da armadura tracionada;

$\varepsilon_{S}^{\prime} \quad$ Deformação específica da armadura comprimida;

$f_{c k} \quad$ Resistência característica à compressão do concreto aos 28 dias;

$f_{s d} \quad$ Tensão de escoamento de projeto do aço das armaduras;

$f_{y} \quad$ Tensão de escoamento do aço do perfil;

$f_{y d} \quad$ Tensão de escoamento de projeto do aço dos perfis;

$f_{y s} \quad$ Tensão de escoamento do aço das armaduras;

$F_{a t} \quad$ Força externa atuante na seção;

$F_{c} \quad$ Parcela da força interna da seção referente ao concreto não fissurado; 
$F_{c h C} \quad$ Parcela da força interna da seção referente ao perfil comprimido;

$F_{c h T} \quad$ Parcela da força interna da seção referente ao perfil tracionado;

$F_{S}$

Parcela da força interna da seção referente as armaduras tracionadas;

$F_{s}^{\prime} \quad$ Parcela da força interna da seção referente as armaduras comprimidas;

$\varphi \quad$ Coeficiente de fluência do concreto;

$h \quad$ Altura da seção transversal;

$h_{n} \quad$ Altura da linha neutra plástica da seção transversal;

$I_{a} \quad$ Momento de inércia da seção transversal do perfil de aço;

$I_{c} \quad$ Momento de inércia da seção transversal do concreto não fissurado;

$I_{a} \quad$ Momento de inércia da seção transversal da armadura;

KL Comprimento de flambagem do pilar;

L Vão da viga;

$\lambda_{\text {rel }} \quad$ Esbeltez relativa;

$M_{p l, R d} \quad$ Momento plástico resistente de projeto;

$M_{\text {máx,Rd }}$ Momento plástico resistente máximo de projeto;

$N_{e} \quad$ Força axial de flambagem elástica;

$N_{G, S d} \quad$ Parcela da força axial solicitante de cálculo devida à ação permanente e à ação do uso de atuação quase permanente;

$N_{p l, R d} \quad$ Força axial de compressão resistente de cálculo da seção transversal à plastificação total;

$N_{p l, a, R d}$ Força axial de compressão resistente de cálculo à plastificação do aço do perfil;

$N_{p l, c, R d}$ Força axial de compressão resistente de cálculo à plastificação do concreto;

$N_{p l, s, R d}$ Força axial de compressão resistente de cálculo à plastificação do aço das armaduras;

$N_{S d} \quad$ Força normal solicitante de projeto;

t Espessura do perfil de aço;

Resistência limite de cisalhamento entre aço e concreto que

$\tau_{R d} \quad$ dispensa o uso de conectores;

$\mathrm{x} \quad$ Altura da linha neutra;

$\chi \quad$ Fator de redução;

$y_{c h} \quad$ Posição do centroide do perfil de aço. 


\section{Introdução}

\section{1.}

\section{Considerações iniciais}

O avanço da construção mista ao longo da história está intimamente ligado ao desenvolvimento do concreto armado e das estruturas em aço. No início do século passado, o concreto era utilizado nas construções mistas como material de revestimento, protegendo os perfis de aço contra o fogo e a corrosão.

Embora o concreto tivesse uma participação em termos estruturais, sua contribuição na resistência era desprezada nos cálculos. Hoje, contando com as vantagens dos dois materiais, as estruturas mistas são cada vez mais viáveis e, portanto, utilizadas.

As características dos dois materiais são diferentes e complementares. O concreto alia a resistência à compressão, elevada rigidez e proteção contra o fogo e a corrosão. $\mathrm{O}$ aço, por sua vez, apresenta elevada resistência à tração e proporciona esbeltez aos elementos.

Ambos os materiais apresentam coeficientes de dilatação térmica próximos, o que não resulta em deformações térmicas diferenciais relativas. Segundo a ABNT NBR 8800:2008, as estruturas mistas surgem quando ambos os materiais trabalham solidariamente entre si, sem que haja deslocamento relativo relevante entre eles, comportando-se basicamente como um só material.

Os pilares mistos apresentam como principais vantagens a esbeltez, quando comparados a pilares de concreto, maior rigidez, quando comparados a pilares metálicos e proteção contra corrosão e contra incêndio. Além disso, os pilares mistos apresentam certas vantagens referentes a sua viabilidade econômica, como por exemplo, a redução de formas e escoramentos, a redução do tempo de execução da obra, e a redução do consumo de aço estrutural.

O tipo de pilar misto estudado nesse trabalho, além das vantagens já mencionadas, usufrui do acabamento que as peças de aço utilizadas fornecem, bem como da alta resistência desses perfis de aço, tornando o estudo diferenciado. 
Em pilares mistos, geralmente, utiliza-se perfis soldados ou laminados, ou tubos de aço, a utilização de perfis de chapa dobrada e espessura fina tem o objetivo de aproveitar a leveza do material. O baixo peso desses perfis utilizados, torna o processo de construção mais simples, podendo ser uma solução prática para pequenas construções.

\section{2.}

\section{Objetivos}

O presente trabalho tem como objetivo estudar e avaliar o comportamento de pilares mistos de aço de alta resistência, a partir de ensaios experimentais e prescrições normativas.

Os pilares mistos estudados são compostos por dois perfis $U$ enrijecidos de chapa fina de aço de alta resistência e concreto armado, formando uma seção retangular.

Para realizar essa pesquisa leva-se em consideração os três materiais envolvidos, concreto, aço dos perfis e aço das armaduras, bem como ensaios de compressão axial, flexão e compressão excêntrica.

\section{3.}

\section{Revisão bibliográfica}

"GRIFFIS (1994) aponta os Laboratórios de Engenharia Civil da Universidade de Columbia como os primeiros a desenvolverem os ensaios em pilares mistos em 1908, enquanto FURLONG (1988) cita Burr como um dos pioneiros nos ensaios também em 1908. De qualquer forma as pesquisas tiveram continuidade em trabalhos que buscavam mostrar que um pilar de aço revestido com concreto tinha capacidade de carga maior que o de um pilar de aço isolado.” (Figueiredo, 1998)

Não se sabe ao certo quando os pilares mistos começaram a ser pesquisados, mas sabe-se que o intuito inicial era proteger pilares de aço contra o fogo e a corrosão, até perceberem que, além de proteger, o concreto ajudava na capacidade de carga do pilar.

Nas Tabela 1 e Tabela 2 são apresentadas algumas pesquisas publicadas sobre os pilares mistos ao longo dos anos. E no capítulo 2 apresenta-se um pouco mais sobre a história das construções mistas e dos pilares mistos, bem como suas vantagens, tipos e aplicações. 
Tabela 1 - Panorama de alguns dos trabalhos realizados sobre pilares mistos (Adaptada de FABRIZZI, 2009 e KENNEDY \& MacGREGOR, 1984) - Parte I.

\begin{tabular}{|c|c|}
\hline Pesquisador(es) (ano) & Observações sobre os trabalhos realizados \\
\hline JONES, RIZK (1963) & $\begin{array}{l}\text { Estudaram o comportamento de pilares mistos totalmente } \\
\text { revestidos, ensaios foram realizados e concluíram que o } \\
\text { revestimento contribui para a capacidade de carga. }\end{array}$ \\
\hline FURLONG (1967) & $\begin{array}{l}\text { Propôs um método alternativo para a deter } \\
\text { carga axial última para pilares mistos pre }\end{array}$ \\
\hline FURLONG (1968) & $\begin{array}{l}\text { Publicou no ASCE Journal recomendações para projeto de } \\
\text { vigas-colunas mistas revestidas. }\end{array}$ \\
\hline $\begin{array}{l}\text { BASU, SOMMERVILLE } \\
\text { (1969) }\end{array}$ & $\begin{array}{l}\text { Propuseram uma derivação de fórmula para o } \\
\text { dimensionamento de colunas mistas retangulares. }\end{array}$ \\
\hline $\begin{array}{l}\text { KNOWLES, PARK } \\
\text { (1970) }\end{array}$ & $\begin{array}{l}\text { Estudaram o projeto de pilares de tubos de aço preenchidos } \\
\text { com concreto submetidos a cargas axiais. }\end{array}$ \\
\hline $\begin{array}{l}\text { VIRDI, DOWLING } \\
\qquad(1973)\end{array}$ & $\begin{array}{l}\text { Realizaram uma série de ensaios experimentais de pilares } \\
\text { mistos totalmente revestidos, os resultados mostraram que } \\
\text { há uma perda de resistência para pilares com } \\
\text { comprimentos maiores e maiores excentricidades de carga. }\end{array}$ \\
\hline WAKABAYASHI (1977) & $\begin{array}{c}\text { Propôs um novo método de projeto } \mathrm{p} \\
\text { esbeltas. }\end{array}$ \\
\hline $\begin{array}{l}\text { COMITÉ E } \\
\text { INTERNACIO } \\
\text { BÉTON (CEF }\end{array}$ & $\begin{array}{l}\begin{array}{l}\text { Primeira recomendação sobre dimensionamento de pilares } \\
\text { mistos. }\end{array}\end{array}$ \\
\hline REDWOOD (1981) & $\begin{array}{l}\text { Apresentou o tratamento de pilares mistos no S16.1, norma } \\
\text { canadense. }\end{array}$ \\
\hline $\begin{array}{c}\text { KENNEDY, } \\
\text { MacGREGOR (1984) }\end{array}$ & $\begin{array}{l}\text { Estudaram o efeito dos apoios na resistência de vigas- } \\
\text { colunas mistas preenchidas. }\end{array}$ \\
\hline MIRZA (1989) & $\begin{array}{l}\text { Estudou as diversas variáveis que interferem na resistência } \\
\text { dos pilares revestidos. }\end{array}$ \\
\hline $\begin{array}{l}\text { RICK, BERGMANN } \\
\text { (1990) }\end{array}$ & $\begin{array}{l}\text { Propuseram um método de dimensionamento de pilares } \\
\text { mistos de seção assimétrica, verificando esse método com } \\
\text { ensaios experimentais. }\end{array}$ \\
\hline $\begin{array}{l}\text { MIRZA, SKRABERCK } \\
(1991)\end{array}$ & $\begin{array}{l}\text { Pesquisaram a influência de vários fatores na resistência de } \\
\text { pilares mistos curtos totalmente revestidos, de seção } \\
\text { quadrada. }\end{array}$ \\
\hline $\begin{array}{l}\text { HUNAITI, FATTAH } \\
\text { (1994) }\end{array}$ & $\begin{array}{l}\text { Realizaram ensaios experimentais de pilares mistos, } \\
\text { parcialmente revestidos, submetidos à carga axial } \\
\text { excêntrica ao longo do eixo de maior inércia. }\end{array}$ \\
\hline UY (1996) & $\begin{array}{l}\text { Propôs uma nova avaliação para o comportamento de } \\
\text { pilares mistos preenchidos retangulares após a flambagem } \\
\text { local da parede do perfil. }\end{array}$ \\
\hline KATO (1996) & $\begin{array}{l}\text { Apresentou um estudo das curvas de flambagem dos } \\
\text { pilares mistos demonstrando que as curvas utilizadas para } \\
\text { perfis de aço isolados podem ser aplicáveis para pilares } \\
\text { mistos com algumas adaptações. }\end{array}$ \\
\hline
\end{tabular}


Tabela 2 - Panorama de alguns dos trabalhos realizados sobre pilares mistos (Adaptada de FABRIZZI, 2009 e KENNEDY \& MacGREGOR, 1984) - Parte II.

\begin{tabular}{|c|c|}
\hline Pesquisador(es) (ano) & Observações sobre os trabalhos realizados \\
\hline UY (1998) & $\begin{array}{l}\text { Realizou ensaios com pilares mistos tubulares axialmente } \\
\text { comprimidos e concluiu que o comprimento da onda } \\
\text { formada na região com flambagem local é igual ao lado da } \\
\text { seção no caso de seções quadradas. }\end{array}$ \\
\hline FIGUEIREDO (1998) & $\begin{array}{l}\text { Apresentou em sua dissertação de mestrado aspectos } \\
\text { práticos de projeto e construção de pilares mistos aço- } \\
\text { concreto. }\end{array}$ \\
\hline DE NARDIN (1999) & $\begin{array}{l}\text { Apresentou um estudo teórico-experimental de pilares } \\
\text { mistos compostos por tubos de aço preenchidos por } \\
\text { concreto de alta resistência. }\end{array}$ \\
\hline WANG (1999) & $\begin{array}{l}\text { Realizou testes com pilares mistos esbeltos com o intuito } \\
\text { de calibrar resultados para o EUROCODE } 4 \text { (2004) com a } \\
\text { BSI } 5950 \text { (1900) e verificar a precisão de um novo método. }\end{array}$ \\
\hline $\begin{array}{l}\text { SHANMUGAM, } \\
\text { LAKSHMI (2001) }\end{array}$ & $\begin{array}{l}\text { Apresentaram um estado da arte atual dos pilares mistos } \\
\text { revestidos e preenchidos com ênfase em estudos } \\
\text { experimentais e analíticos. }\end{array}$ \\
\hline HAN (2002) & $\begin{array}{l}\text { Investigou experimentalmente pilares mistos preenchidos } \\
\text { de seção retangular submetidos à carga axial. }\end{array}$ \\
\hline $\begin{array}{l}\text { GIAKOUMELIS, LAM } \\
\text { (2004) }\end{array}$ & $\begin{array}{l}\text { Estudaram o comportamento de tubos de aço circulares } \\
\text { preenchidos com concreto, comparando resultados de } \\
\text { ensaios com as recomendações de normas técnicas. }\end{array}$ \\
\hline LIN-HAI HAN (2005) & $\begin{array}{l}\text { Estudou o comportamento de pilares mistos circulares } \\
\text { preenchidos submetidos a carregamentos cíclicos axial e de } \\
\text { flexão. }\end{array}$ \\
\hline FABRIZZI (2009) & $\begin{array}{l}\text { Abordou aspectos e recomendações normativas em projeto } \\
\text { e dimensionamento de edifícios de múltiplos andares com } \\
\text { elementos estruturais mistos. }\end{array}$ \\
\hline $\begin{array}{l}\text { EKMKYAPAR, AL- } \\
\text { ELIWI (2016) }\end{array}$ & $\begin{array}{l}\text { Estudaram experimentalmente tubos circulares de aço } \\
\text { preenchidos com concreto e as considerações normativas. }\end{array}$ \\
\hline
\end{tabular}

\subsection{Organização da Dissertação}

Esta dissertação está dividida em seis capítulos, incluindo este primeiro capítulo, introdutório, que apresenta as considerações iniciais, os objetivos, uma breve revisão bibliográfica e a forma como a dissertação é organizada em capítulos.

No capítulo 2 apresenta-se uma revisão das considerações gerais sobre o projeto de pilares mistos, seus tipos, suas características e suas vantagens, bem como os fatores que influenciam na resistência dos mesmos. Nesse capítulo são apresentados também, os aspectos estruturais pertinentes aos pilares mistos de forma geral como o dimensionamento conforme as normas brasileira e europeia.

No capítulo 3 detalha-se o programa experimental de todos os ensaios realizados, incluindo a caracterização dos materiais utilizados. Apresenta a 
fabricação das peças e cada etapa dos ensaios de compressão, flexão e flexocompressão.

No capítulo 4 são apresentados os resultados obtidos experimentalmente e no capítulo 5 esses resultados são analisados e comparados com as considerações normativas e modelos teóricos.

Finalmente, no capítulo 6, relatam-se as principais conclusões obtidas ao longo da dissertação e sugestões para trabalhos futuros. E, em seguida, três apêndices apresentam memórias de cálculos de valores mencionados no quinto capítulo. 


\section{2 \\ Projeto de pilares mistos}

\section{1. \\ Estruturas mistas de aço e concreto}

Estruturas mistas de aço e concreto são sistemas que apresentam o comportamento interativo de componentes de aço estrutural com elementos de concreto a fim de resistir às ações externas. Esse comportamento é proporcionado pela tensão de aderência entre o aço e o concreto, ou, se esta for excedida, por conectores de cisalhamento. O objetivo desses sistemas é aproveitar ao máximo das vantagens que cada um dos materiais pode oferecer.

Segundo FIGUEIREDO, 1998, as primeiras construções mistas nos Estados Unidos foram uma ponte e um edifício, construídos, em 1894, usando vigas de aço revestidas com concreto como alternativa de proteção ao fogo e à corrosão. De acordo com MALITE, 1990, os estudos sobre estruturas mistas iniciaram antes da primeira guerra mundial, onde na Inglaterra, em 1914, a empresa Redpath Brow and Company iniciou uma série de ensaios de sistemas mistos para pisos.

Ainda segundo MALITE, 1990, pode-se dizer que em 1930 o sistema já estava definido e os métodos de dimensionamento estabelecidos, e, entre 1922 e 1939, foram construídos muitos edifícios e pontes que adotavam o sistema de vigas mistas.

De acordo com FIGUEIREDO, 1998, o primeiro registro de normatização de estruturas mistas é de 1930, pelo New York Building Code. MALITE, 1990, afirma que em 1944 o assunto foi inserido nas normas da American Association of State Higway Officials (AASHO, hoje em dia denominada AASHTO - American Association of State Highway and Transportation Officials). Afirma ainda que, no Brasil, a construção mista ficou limitada a alguns edifícios pioneiros construídos entre os anos de 1950 e 1960 e pequenas pontes. As estruturas mistas só foram normatizadas no Brasil em 1986 pela ABNT NBR 8800:1986, que se limitava a abordar somente elementos mistos fletidos. 
Segundo BIANCHI, 2002, inicialmente considerava-se que o concreto e o aço agiam independentemente. Em alguns casos, não se levava em consideração a função estrutural do concreto, sendo esse considerado apenas como um material para proteção contra incêndio.

A partir da década de 50, porém, com o desenvolvimento dos conectores de cisalhamento e do processo de soldagem, foi possível considerar o comportamento interativo entre o aço e o concreto para suporte de cargas, tornando viável e competitiva a utilização de sistemas estruturais mistos.

Uma série de vantagens são oferecidas por este sistema em comparação aos sistemas convencionais que utilizam apenas o aço estrutural ou o concreto armado. A seção de aço de uma peça mista, por exemplo, pode ser reduzida em relação a uma peça equivalente de aço apenas, já que o concreto resiste a uma parcela do carregamento atuante. Um elemento misto é, em geral, mais rígido do que um não misto de mesma dimensão e, consequentemente, apresenta menos deformação e vibração, assim como elimina ou reduz os problemas de instabilidade locais e globais.

\section{2.}

\section{Pilares Mistos: tipos e aplicações}

A questão do incêndio sempre foi problemática para as estruturas de aço, portanto, quando surgiram os primeiros pilares mistos o concreto era visto somente como proteção ao fogo. Os ganhos em rigidez e resistência, provenientes da associação dos materiais, não eram computados nos cálculos.

Ao longo dos anos, os pilares mistos de aço e concreto evoluíram e hoje apresentam variações no arranjo e composição desses materiais. Em função da posição que o concreto ocupa na seção, os pilares mistos podem ser classificados em: parcialmente revestidos, revestidos e preenchidos.

O pilar misto é denominado parcialmente revestido quando o concreto é utilizado somente no preenchimento do espaço entre as mesas do perfil I. Um pilar preenchido é formado por um perfil tubular, retangular ou circular, de aço preenchido com concreto. Existem também os pilares tipo battened, formados por dois perfis tipo $U$ ligados por talas e preenchidos com concreto.

Os pilares mistos têm aplicações vantajosas tanto em estruturas de pequeno porte quanto em edifícios altos. Também podem ser empregados em galpões de 
armazenagem, quadras esportivas cobertas, terminais rodoviários, pavilhões. A proteção do perfil de aço com o concreto, nesses casos, seria uma solução desejável, seja por motivos de ordem estética ou de proteção contra a corrosão, incêndio ou eventuais impactos de veículos.

Uma aplicação usual dos pilares mistos é na recuperação de estruturas. O pilar de aço a ser reforçado é facilmente enrijecido e tem ganhos consideráveis em resistência quando é revestido com o concreto. Já em pilares de concreto armado a serem reforçados, a opção de se utilizar perfis ou chapas de aço torna-se interessante uma vez que, diferentemente do reforço com o próprio concreto, não acarreta um aumento significativo da seção transversal a ponto de comprometer a arquitetura da edificação.

\section{3.}

\section{Fatores que influenciam na resistência do pilar misto}

Muitos parâmetros devem ser analisados para avaliar a resistência de um pilar misto, tais como aderência entre aço e concreto, efeito de confinamento do concreto, resistência do concreto, limite de escoamento do aço, fluência, retração do concreto, modo de carregamento, formas da seção transversal, razão entre as áreas do perfil de aço e a área total da seção, entre outros.

Enquanto alguns destes fatores interferem de forma mais significativa na resistência final do pilar, outros não influenciam de forma considerável. A avaliação da interferência de cada um deles é trabalhosa e, portanto, pouco prática para aplicação direta em projeto. Por isso, foram desenvolvidas pesquisas buscando avaliar a interferência destes parâmetros através de análises experimentais e numéricas de modo que viabilizasse a sua aplicação no dimensionamento dos pilares mistos.

Ramasmurthy \& Srinivasan em 1976 apud FIGUEIREDO, 1998, já se preocupavam em esclarecer as interferências de alguns parâmetros, como o modo de carregamento, a aderência e a forma da seção, na resistência do pilar misto. A partir de uma análise experimental, concluiram que o método de carregamento é um fator inportante na resistência e no comportamento do pilar. Concluiram também que pilares preenchidos com seção transversal circular devem ter um tratamento diferente para consideração do efeito de confinamento. 
MIRZA, 1989 estudou as diversas variáveis que interferem na resistência dos pilares revestidos através de um parâmetro adimensional dado pela razão entre uma resistência teórica e uma resistência nominal dada pelas expressões fornecidas pelo ACI 318, 1983 (Última atualização em 2014).

Alguns parâmetros já estão incorporados em normas, entretanto existem pesquisas que os questionam e chamam atenção para a necessidade de mais resultados experimentais e numéricos, a fim de reformular os critérios das normas.

\subsection{1.}

\section{Aderência entre aço e concreto}

Segundo ALVA \& MALITE, 2005, a transferência de esforços na interface dos dois materiais ocorre por aderência. Essa transmissão de esforços pode ser feita simplesmente por adesão e atrito, cuja força é proporcional à área da interface açoconcreto e ao esforço normal aplicado. A transmissão de esforços pode também realizar-se por conexão mecânica, utilizando-se conectores de cisalhamento.

Tabela 3 - Resistência limite de cisalhamento entre o aço e o concreto ( $\left.\boldsymbol{\tau}_{\mathbf{R d}}\right)$ para dispensa do uso de conectores em MPa.

\begin{tabular}{|c|c|c|c|}
\hline & $\begin{array}{c}\text { NBR } 8800 \\
(2008)\end{array}$ & $\begin{array}{c}\text { EuroCode } 4 \\
\text { (2004) }\end{array}$ & $\begin{array}{c}\text { AISC-LFRD } \\
(1994)\end{array}$ \\
\hline $\begin{array}{l}\text { Perfis totalmente } \\
\text { envolvidos por } \\
\text { concreto }\end{array}$ & 0,3 & 0,3 & \multirow{5}{*}{$\begin{array}{l}\text { Quando } \\
\frac{N_{S d}}{N_{R d, p l}} \leq 0,3 \\
\text { não há } \\
\text { necessidade } \\
\text { de conectores }\end{array}$} \\
\hline $\begin{array}{c}\text { Mesas de perfis I } \\
\text { parcialmente } \\
\text { envolvidos por } \\
\text { concreto }\end{array}$ & 0,2 & 0,2 & \\
\hline $\begin{array}{l}\text { Almas de perfis I } \\
\text { parcialmente } \\
\text { envolvidos por } \\
\text { concreto }\end{array}$ & 0 & 0 & \\
\hline $\begin{array}{l}\text { Perfis tubulares } \\
\text { retangulares } \\
\text { preenchidos por } \\
\text { concreto }\end{array}$ & 0,4 & 0,4 & \\
\hline $\begin{array}{l}\text { Perfis tubulares } \\
\text { circulares } \\
\text { preenchidos por } \\
\text { concreto }\end{array}$ & 0,55 & 0,55 & \\
\hline
\end{tabular}

As principais normas aplicáveis a pilares mistos admitem a completa interação entre o perfil de aço e o concreto, principalmente devido ao fato de os 
pilares serem elementos estruturais predominantemente comprimidos e, portanto, submetidos a pequenos esforços de cisalhamento longitudinal.

As normas atuais apresentam valores máximos de aderência nesta interface, de modo que esforços abaixo destes limites dispensam a necessidade de utilização de conectores de cisalhamento, Tabela 3.

\subsection{2. \\ Efeito do confinamento do concreto}

Em pilares revestidos podem-se identificar três regiões de confinamento do concreto: região sem confinamento, externa à armação transversal; região com concreto parcialmente confinado, dentro da armação transversal; região altamente confinada, entre a alma e as mesas da seção de aço. Em pilares preenchidos, o concreto está totalmente confinado.

Em pilares preenchidos, segundo Susantha et. al(2001), Shanmungam e Lakshmi (2001), Johansson (2002b), Johansson e Akesson (2002) e Sakino et. al.(2004) apud OLIVEIRA e EL DEBS, 2009, nas primeiras etapas de carregamento o efeito de confinamento do concreto não é exigido, pelo fato do coeficiente de Poisson do concreto ser menor que o do aço. Nesta fase, o aço está submetido a tensões de compressão e o concreto está em fase de expansão, não havendo ainda a separação entre eles. Contudo, com a elevação da força para intensidades da resistência uniaxial do concreto, o processo de microfissuração se intensifica, o material se expande a ponto de solicitar o tubo de aço, confinando o concreto. Observa-se, então, que o valor da capacidade resistente do pilar preenchido é superior à soma dos valores das parcelas de resistência correspondentes ao tubo de aço e ao núcleo de concreto.

Segundo OLIVEIRA e EL DEBS, 2009, a tensão gerada pelo confinamento é responsável pelo acréscimo na capacidade resistente à compressão uniaxial do pilar preenchido. Nesta situação, o concreto está submetido a um estado triaxial de tensões e o tubo de aço, a um estado biaxial de tensões. Segundo Shams e Saadeghvaziri (1997), Schneider (1998) e Shanmugam e Lakshmi (2001) apud OLIVEIRA e EL DEBS, 2009, apenas os pilares de seção circular apresentam esse acréscimo de resistência devido ao estado triaxial de tensões. Esse acréscimo não é percebido nos pilares de seção quadrada e retangular, uma vez que a face desses pilares não são rígidas o suficiente para resistir à pressão exercida pelo concreto em 
expansão. Nesses casos, apenas o concreto situado na porção mais central e nos cantos da seção estão confinados.

\subsection{3.}

\section{Propriedades do concreto}

Segundo FABRIZZI, 2007, a resistência do concreto está claramente relacionada ao ganho de resistência do pilar misto, porém é mais significativa em pilares curtos e com perfil de aço com limite de escoamento menor.

GIAKOUMELIS \& LAM, 2004, testaram 15 colunas mistas de tubos de aço circulares preenchidos de concreto, e concluiram que a medida que a resistência do concreto aumenta os efeitos na ligação aço e concreto tornaram-se mais críticos.

De acordo com ALVA \& MALITE, 2005, o acréscimo de deformações resultantes da fluência e da retração do concreto pode induzir o escoamento ou a flambagem local do perfil tubular de aço em pilares preenchidos.

A deformação lenta, ou fluência, do concreto em pilares mistos deve ser considerada principalmente em pilares esbeltos e é tratada de forma diferente em cada norma. A ABNT NBR 8800:2008 e o Eurocode 4, 2004, por exemplo, utilizam um módulo de elasticidade reduzido, o que gera deslocamentos maiores.

\subsection{4. \\ Outros fatores}

MIRZA, 1989, em seu estudo teórico, comparou a resistência dos pilares mistos revestidos considerando o efeito das tensões residuais das seções de aço. Para fins comparativos, analisou pilares com diferentes esbeltezes e excentricidades de carga, e verificou que a resistência é afetada pela excentricidade. O efeito é menor quando a excentricidade é maior que 2,0h para pilares curtos ou maior que 1,5h para pilares esbeltos, sendo h a maior dimensão transversal do pilar. Concluiu, portanto, que as tensões residuais prejudicam a resistência do pilar misto e que este efeito é mais evidente em pilares curtos com pequenas excentricidades.

\section{4.}

\section{Dimensionamento segundo as normas técnicas}

As principais normas que tratam do dimensionamento de pilares mistos abordam o assunto sob diferentes aspectos, uma vez que os procedimentos e considerações dos estudos experimentais muitas vezes variam de um país para outro. Segundo BIANCHI, 2002, um projeto adotando-se determinada norma pode 
ser $60 \%$ menos conservador em relação a uma outra norma, apesar de ambas adotatrem os mesmos princípios gerais.

Enquanto algumas normas consideram os pilares mistos como pilares de aço com capacidade estrutural aumentada devido à presença benéfica do concreto, outras consideram o pilar misto como um pilar de concreto com armadura especial, devido à presença do perfil de aço. Existem, também, aquelas que consideram os pilares mistos como combinação dos dois raciocínios, como o Eurocode 4, 2004 e a ABNT NBR 8800:2008.

\subsection{1.}

\section{Norma brasileira}

O Anexo P da ABNT NBR 8800:2008 trata do dimensionamento por método simplificado de pilares mistos com seções transversais total ou parcialmente revestidas com concreto e com seções preenchidas com concreto, submetidas à compressão axial ou à flexo-compressão. Esse método simplificado é aplicável para pilares mistos com: dupla simetria e seção transversal constante; concreto de densidade normal; fator de contribuição do aço, $\delta$, (ver eq. (2.1)) entre 0,2 e 0,9; esbeltez relativa, $\lambda_{r e l}$, não maior que 2,0, eq. (2.4). A ABNT NBR8800:2008 exige, ainda, que o projeto de armadura atenda a ABNT NBR 6118:2014; e dependendo do tipo do pilar misto deve atender a alguns outros critérios específicos.

Se $\delta$ for igual ou inferior a 0,2 , o pilar deve ser dimensionado de acordo com a ABNT NBR 6118:2014 como pilar de concreto e, se $\delta$ for igual ou superior a 0,9 o pilar deve ser dimensionado segundo a própria ABNT NBR 8800:2008, como um pilar de aço.

$$
\delta=\frac{A_{a} f_{y d}}{N_{p l, R d}}
$$

A força axial de compressão resistente de cálculo da seção transversal à plastificação total, $N_{p l, R d}$, é dada pela eq. (2.2).

$$
N_{p l, R d}=N_{p l, a, R d}+N_{p l, c, R d}+N_{p l, s, R d}
$$

Onde: $N_{p l, a, R d}=f_{y d} A_{a}, N_{p l, c, R d}=f_{c d 1} A_{c}$ e $N_{p l, s, R d}=f_{s d} A_{s}$ são as forças resistentes de cálculo de seus componentes, perfil de aço, concreto e armadura longitudinal respectivamente; $A_{a}$ é a área da seção transversal do perfil de aço; $A_{s}$ é a área da seção transversal da armadura longitudinal; $A_{c}$ é a área da seção transversal do concreto; $f_{c d 1}$ é igual ao produto $\alpha f_{c d} ; \alpha$ é um coeficiente igual a 
0,95 para seções tubulares circulares preenchidas com concreto e 0,85 para as demais seções.

Vale ressaltar que a resistência de cálculo $f_{d}$ de um material é definida pela ABNT NBR 8800:2008 como $f_{d}=f_{k} / \gamma_{m}$, onde $f_{k}$ é a resistência característica ou nominal e $\gamma_{m}$ é o coeficiente de ponderação de resistência. Esse coeficiente de ponderação é tabelado para aço estrutural, concreto e aço das armaduras para diferentes combinações no Estado Limite Último.

A força axial resistente de cálculo de pilares mistos axialmente comprimidos sujeitos à instabilidade por flexão é dada pela eq. (2.3), onde $\chi$ é o fator de redução, fornecido pela norma, em função do índice de esbeltez $\lambda_{r e l}$, eq. (2.4). Para pilares mistos sujeitos aos efeitos combinados de força axial de compressão e momento fletor em relação a um ou aos dois eixos de simetria da seção transversal a norma apresenta dois métodos para verificação dos efeitos da força axial de compressão e dos momentos fletores, um mais simplificado e um mais rigoroso.

O método mais simplificado e também conservador, utiliza as mesmas fórmulas usadas para verificar pilares somente de aço, apesar de algumas definições serem alteradas.

$$
N_{R d}=\chi N_{p l, R d}
$$

$$
\lambda_{r e l}=\sqrt{\frac{N_{p l, R}}{N_{e}}}
$$

Onde:

$$
\begin{gathered}
N_{p l, R}=f_{y} A_{a}+\alpha f_{c k} A_{c}+f_{y s} A_{s} \\
N_{e}=\frac{\pi^{2}(E I)_{e}}{(K L)^{2}} \\
(E I)_{e}=E_{a} I_{a}+0,6 E_{c, r e d} I_{c}+E_{s} I_{s} \\
E_{c, \text { red }}=\frac{E_{c}}{1+\varphi\left(\frac{N_{G, S d}}{N_{S d}}\right)}
\end{gathered}
$$

Sendo KL o comprimento de flambagem do pilar, determinado na própria norma; $I_{a}$ o momento de inércia da seção transversal do perfil de aço; $A_{a}$ a área da seção transversal do perfil de aço; $I_{S}$ o momento de inércia da seção transversal da armadura do concreto; $A_{S}$ a área da seção transversal da armadura do concreto; $I_{C} \mathrm{O}$ momento de inércia da seção transversal do concreto não fissurado; $A_{c}$ a área da 
seção transversal do concreto não fissurado. Os módulos de elasticidade são fornecidos pela norma, $E_{a}$ o do aço estrutural; $E_{s}$ do aço da armadura e $E_{c}$ o do concreto.

O coeficiente de fluência do concreto, $\varphi$, é de forma simplificada, 2,5 para as seções total ou parcialmente revestidas com concreto e zero nas seções tubulares preenchidas.

De forma simplificada, $\frac{N_{G, S d}}{N_{S d}}=0,6$; onde $N_{S d}$ é a força axial solicitante de cálculo; $N_{G, S d}$ é a parcela da força axial solicitante de cálculo devida à ação permanente e à ação decorrente do uso de atuação quase permanente.

\subsection{2.}

\section{Eurocode}

A seção do Eurocode 4, 2004 que trata de colunas mistas e elementos mistos comprimidos serviu de base para o Anexo $\mathrm{P}$ da norma brasileira, portanto as considerações são semelhantes, com diferenças sutis e considerações adicionais. É aplicável em elementos que possuem seções revestidas, parcialmente revestidas ou preenchidas de concreto; são formadas por aço grau S235 até S460 e concreto de densidade normal e resistência entre 20 e $60 \mathrm{MPa}$; e cujo fator de contribuição do aço, $\delta$, é maior ou igual a 0,2 e menor ou igual a 0,9 .

A Figura 2.1 apresenta os tipos de pilares mistos abordados nessa norma, (a) totalmente revestido, (b) e (c) parcialmente revestidos, (d) e (e) totalmente preenchidos e (f) seção circular com perfil I adicionado preenchido de concreto.

Assim como a norma brasileira, o Eurocode 4, 2004, apresenta dois métodos de cálculo, um geral e um simplificado. O método geral leva em conta os efeitos de segunda ordem incluindo tensões residuais, imperfeições geométricas, instabilidade local, fissuração, fluência e retração do concreto e tensão de escoamento do aço estrutural e da armadura.

O método simplificado de cálculo é limitado aos elementos com: dupla simetria e seção transversal constante ao longo do comprimento; perfis de aço laminado, formado a frio ou soldado; esbeltez relativa, $\lambda_{\text {rel }}$, calculada da mesma forma que na norma brasileira e apresentada na eq. (2.4), menor ou igual a 2,0; razão entre profundidade e a largura da seção transversal mista entre 0,2 e 5,0. 
A força axial de compressão resistente de cálculo à plastificação total, $N_{p l, R d}$, é determinado da mesma forma apresentada pela norma brasileira, porém o coeficiente $\alpha$ deve ser tomado como 1,0 no caso de seções preenchidas.

A resistência à compressão e flexão combinadas de uma seção transversal e a curva de interação correspondente podem ser calculadas assumindo blocos de tensão retangulares como mostrado na Figura 2.2, levando em conta a força de cisalhamento de projeto, $V_{E d}$. A resistência à tração do concreto deve ser desprezada.

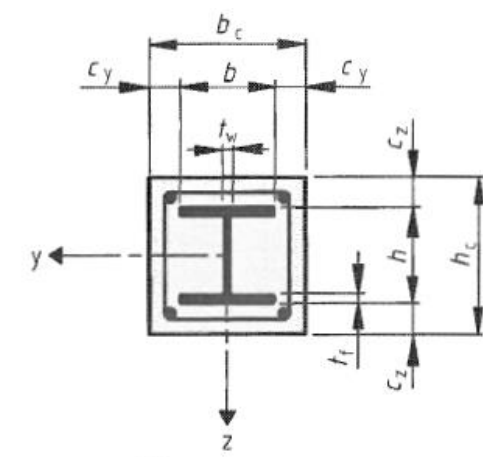

(a)

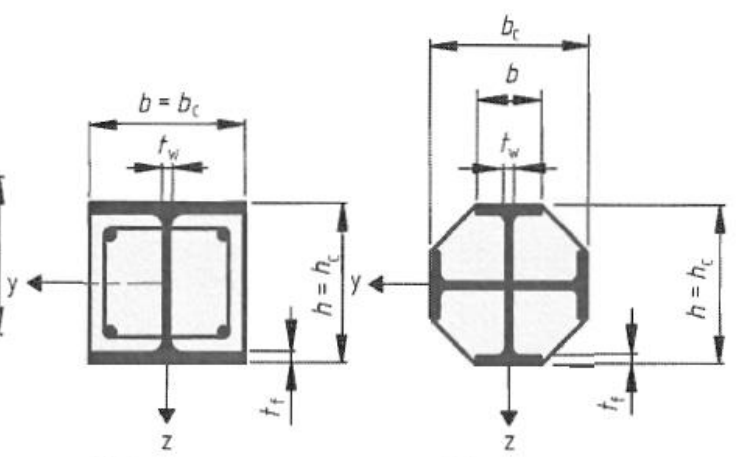

(b) (c)

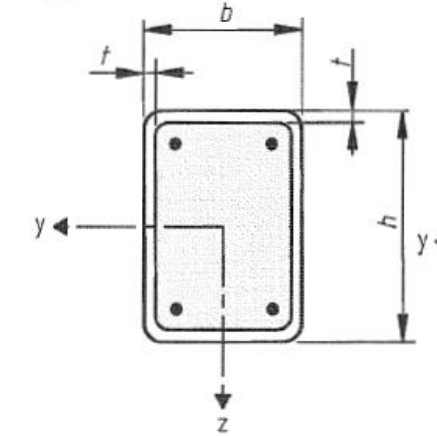

(d)

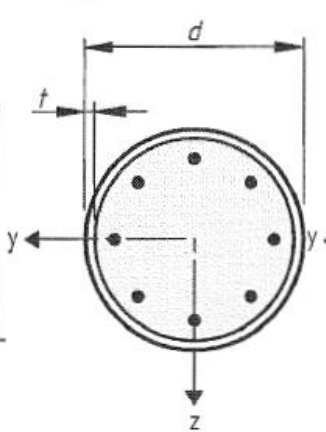

(e)

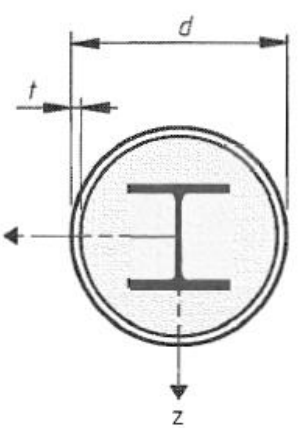

(f)

Figura 2.1 - Seções transversais típicas de pilares mistos (Eurocode 4, 2004).

Se a força de cisalhamento $V_{a, E d}$ na seção de aço exceder $50 \%$ da força cortante resistente de projeto do aço, $V_{p l, a, R d}$, a influência da força cortante na resistência à flexão e normal deve ser considerada quando determina-se a curva de interação. Quando $V_{a, E d}>0,5 V_{p l, a, R d}$ a influência do cisalhamento na resistência à compressão e flexão combinados deve ser levado em conta pela redução da resistência de projeto do aço $(1-\rho) f_{y d}$ na área de cisalhamento $A_{v},($ Figura 2.2).

A menos que uma análise mais cuidadosa seja usada, $V_{E d}$ pode ser distribuída entre $V_{a, E d}$ atuando no aço estrutural e $V_{c, E d}$ atuando no concreto armado, como nas eq. (2.9) e (2.10), onde $M_{p l, a, R d}$ é o momento plástico resistente na seção de aço; 
$M_{p l, R d}$ é o momento plástico resistente na seção mista. Para simplificar, pode-se assumir que o $V_{E d}$ atua na seção de aço somente.

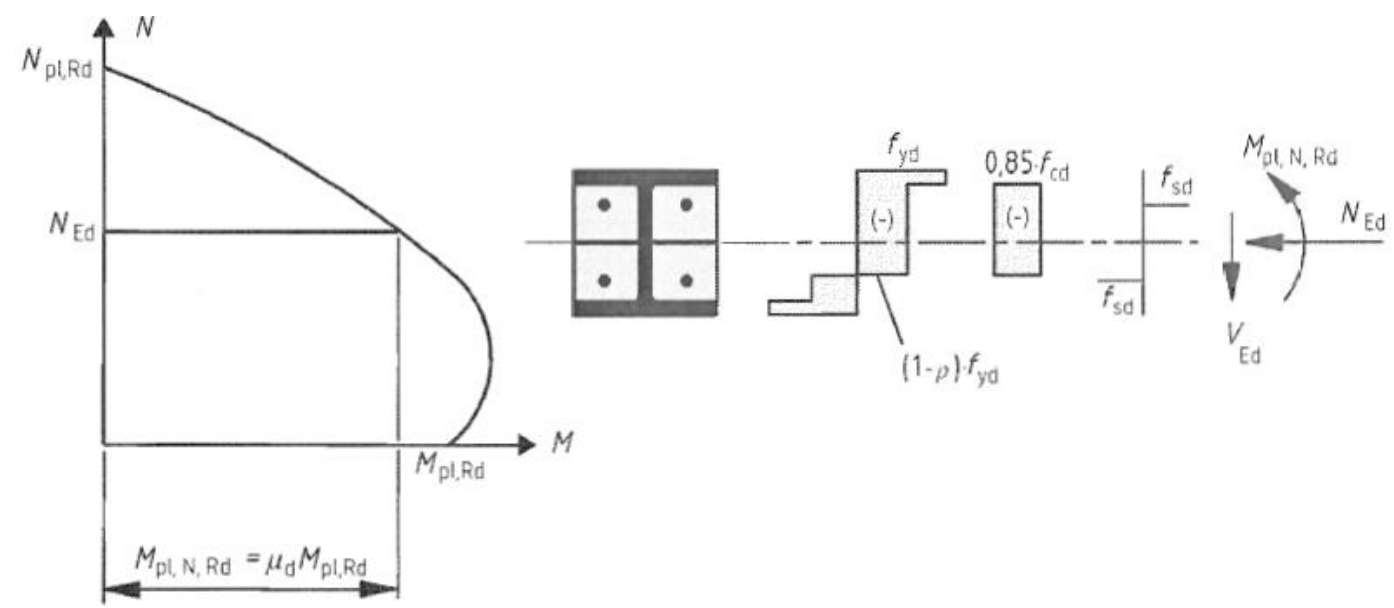

Figura 2.2 - Curva de interação para combinação de compressão e momento uniaxial (Eurocode 4, 2004).

$$
\begin{aligned}
V_{a, E d} & =V_{E d} \frac{M_{p l, a, R d}}{M_{p l, R d}} \\
V_{c, E d} & =V_{E d}-V_{a, E d}
\end{aligned}
$$

A Figura 2.3 apresenta como exemplo a distribuição de tensões plásticas de uma seção revestida para os pontos A, B, C e D. Como uma simplificação, a curva de interação pode ser substituída por um diagrama polinomial (linha tracejada na Figura 2.3). $N_{p m, R d}$ deve ser tomada como $0,85 f_{c d} A_{c}$ para seções revestidas ou parcialmente revestidas, ver Figura 2.1(a)-(c), e como $f_{c d} A_{c}$ para seções preenchidas de concreto, Figura 2.1(d)-(f). 


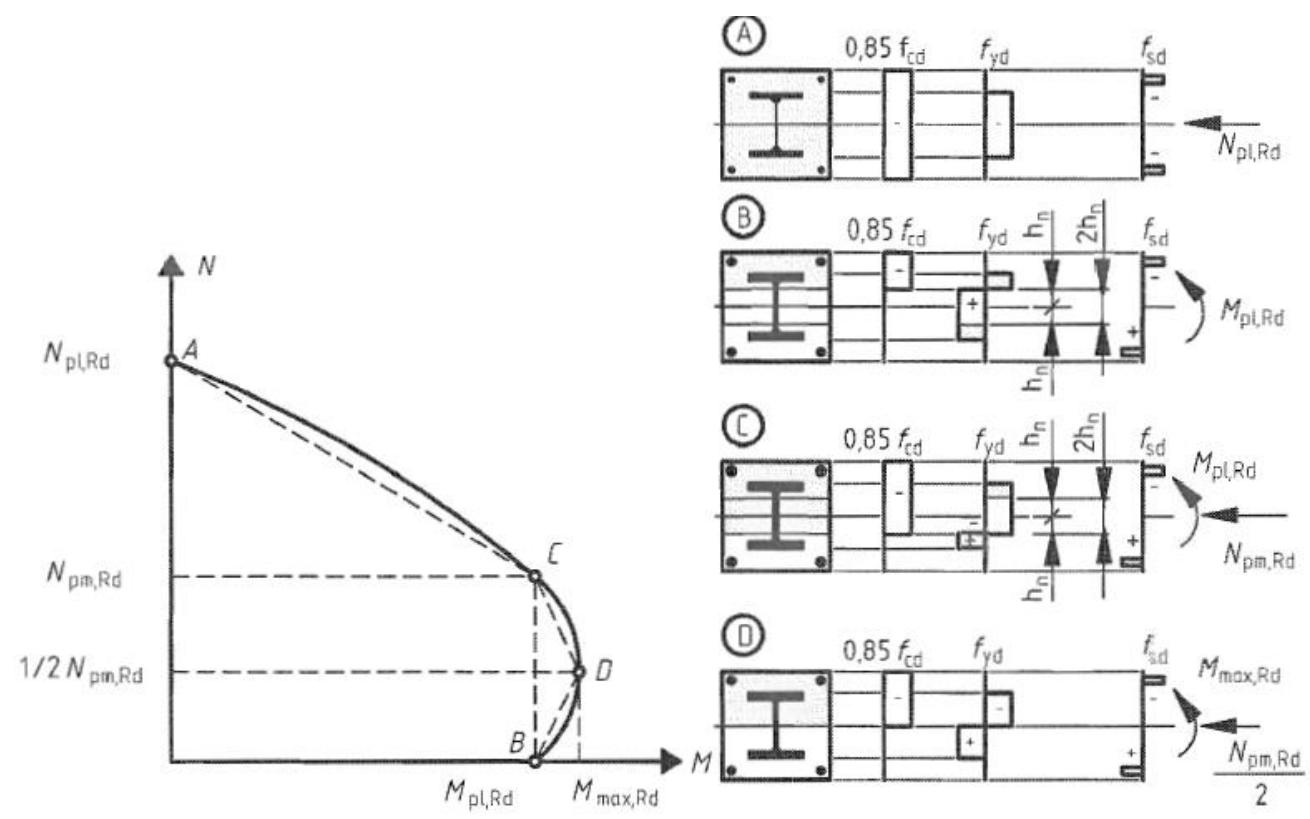

Figura 2.3 - Curva de interação simplificada e distribuições de tensões correspondentes (Eurocode 4 , 2004). 


\section{3 \\ Programa experimental}

\section{1. \\ Considerações gerais}

Este capítulo apresenta o programa experimental executado em laboratório abrangendo a preparação das seis peças mistas de aço e concreto, o sistema de aplicação e medição de esforços, instrumentação e a configuração global de cada ensaio. Os resultados obtidos a partir dos ensaios serão apresentados no capítulo 4 e discutidos no capítulo 5.

É importante ressaltar que o trabalho experimental foi realizado em conjunto com João Domingos Guarçoni Paiva, Daniel Santos de Carvalho, Matheus Justo de Figueiredo e Rafael Ribeiro Moliterno, alunos da graduação em engenharia civil nessa mesma universidade.

Neste trabalho o programa experimental foi composto por seis ensaios de elementos estruturais mistos de aço e concreto, bem como os ensaios de caracterização dos materiais que compõem as peças. Todos os seis elementos estruturais ensaiados possuem a mesma seção transversal, ver Figura 3.2.

Um par de colunas, de 1,5 m cada, foi comprimido axialmente, outro par, de vigas, de $4 \mathrm{~m}$ de comprimento, foi testado à flexão e por último, o par restante, de 1,5 m de comprimento, recebeu carregamento excêntrico, sofrendo flexocompressão. Esses comprimentos foram limitados principalmente pelo espaço disponível e capacidade dos equipamentos no laboratório.

Os perfis de aço utilizados eram cordas de uma treliça, conforme Figura 3.1, e não possuem seção constante ao longo do comprimento. Na Figura 3.2, é possível observar as seções transversais dos perfis, de 1,25 mm de espessura. A Figura 3.3 esclarece o motivo da descontinuidade do enrijecedor e porque os perfis não possuem seção continua ao longo do comprimento.

Os vergalhões constituintes da armação longitudinal são de aço CA-50 com diâmetro de $10 \mathrm{~mm}$ e para atender a ABNT NBR 6118:2014, foram colocados estribos fechados de aço CA-60 com 5 mm de diâmetro, espaçados a cada $120 \mathrm{~mm}$. 


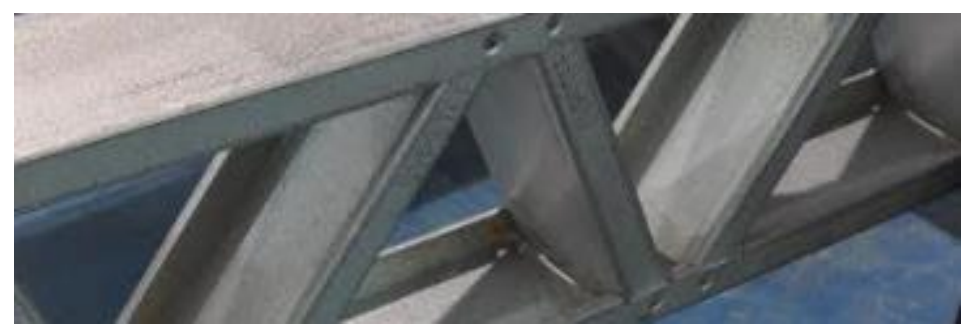

Figura 3.1 - Treliça formada de perfis de chapa fina.

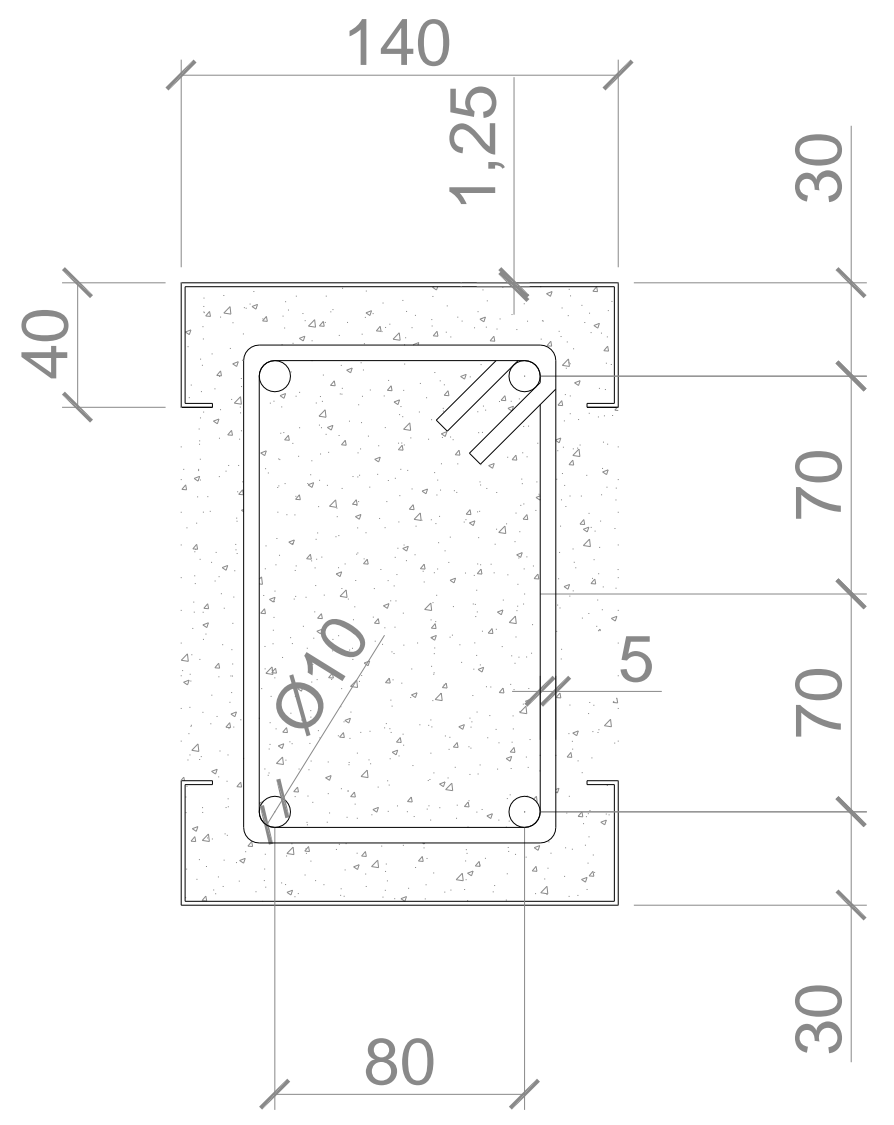

Figura 3.2 - Seção transversal das peças, dimensões em mm.

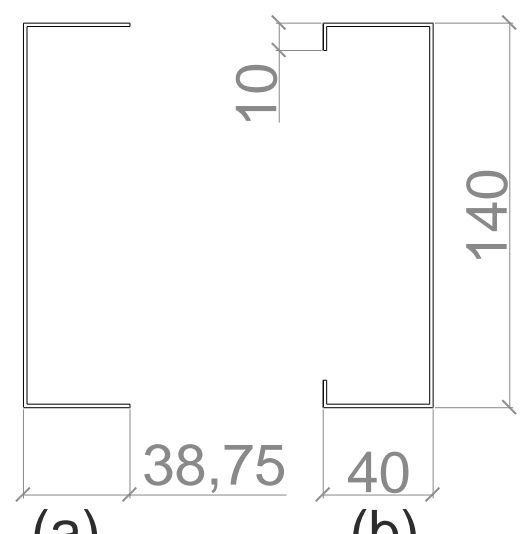

(a)

(b)

Figura 3.3 - Seções transversais dos perfis de aço de alta resistência, (a) seção sem enrijecedor e (b) seção com o enrijecedor (dimensões em mm). 


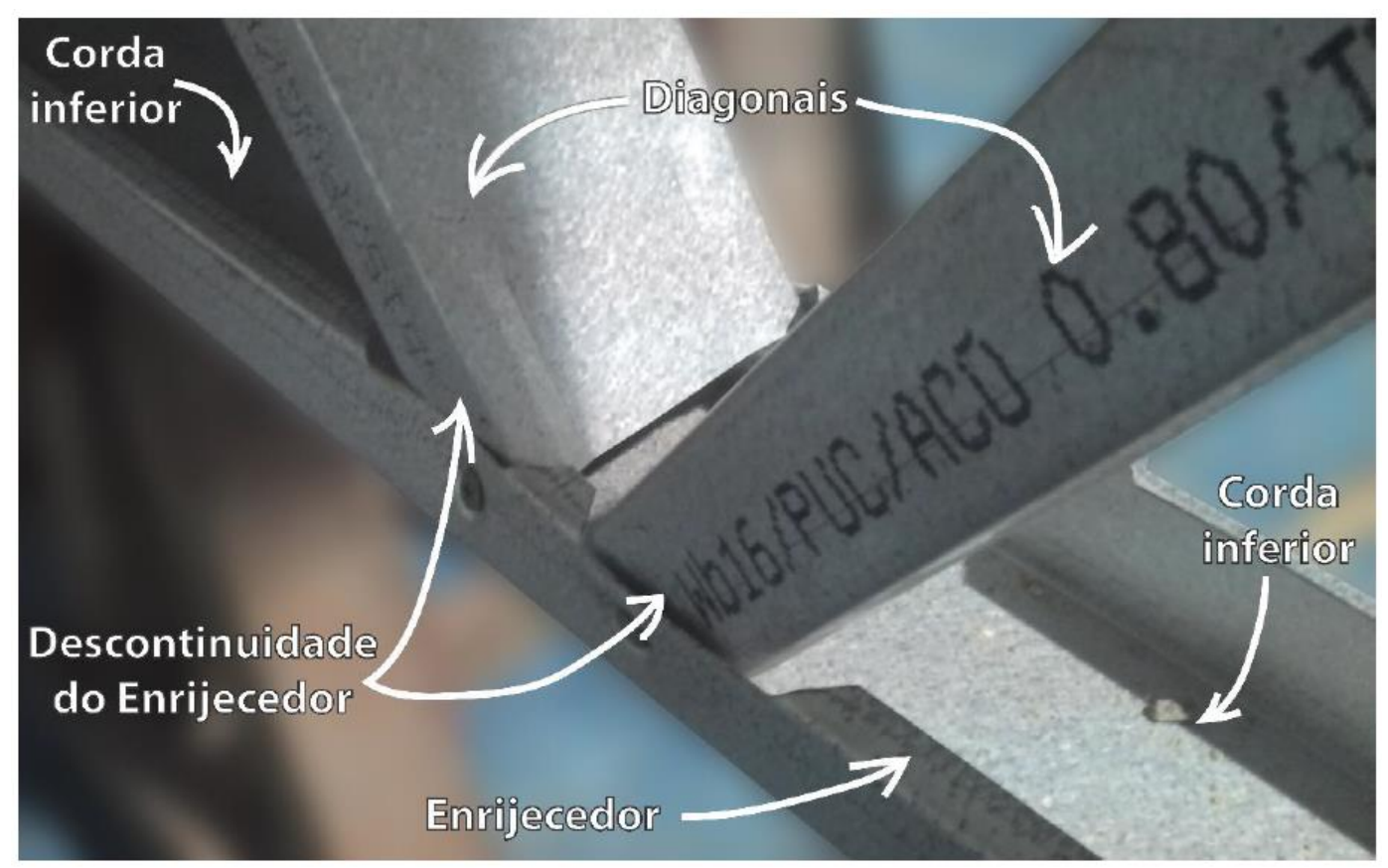

Figura 3.4 - Foto da ligação da treliça para mostrar descontinuidade da seção do perfil. (DALTRO, 2016)

\section{2. Processo de construção}

Após ser definido o tipo de seção a ser analisada, foi iniciado o processo de montagem das peças. Primeiramente, para a obtenção dos perfis de aço desmontouse a estrutura treliçada (Figura 3.4), e retirou-se as cordas superiores e inferiores, as quais posteriormente foram cortadas nos comprimentos das peças mistas estudadas.

As barras longitudinais e os estribos foram cortados, nas dimensões adequadas, e foram devidamente dobradas e amarradas para montagem da armadura. As armaduras foram então encaixadas entre os perfis e a forma, e espaçadores de plástico de $25 \mathrm{~mm}$ foram posicionados para assegurar o cobrimento e a posição correta das armaduras, Figura 3.5.

Com o concreto devidamente dosado, realizou-se a concretagem das peças, sendo usado um vibrador de imersão para o adensamento, e então a mistura foi cuidadosamente nivelada. Após a cura as peças foram retiradas da forma, e depois de esperados os 28 dias da concretagem as peças estavam prontas para iniciar os ensaios. 


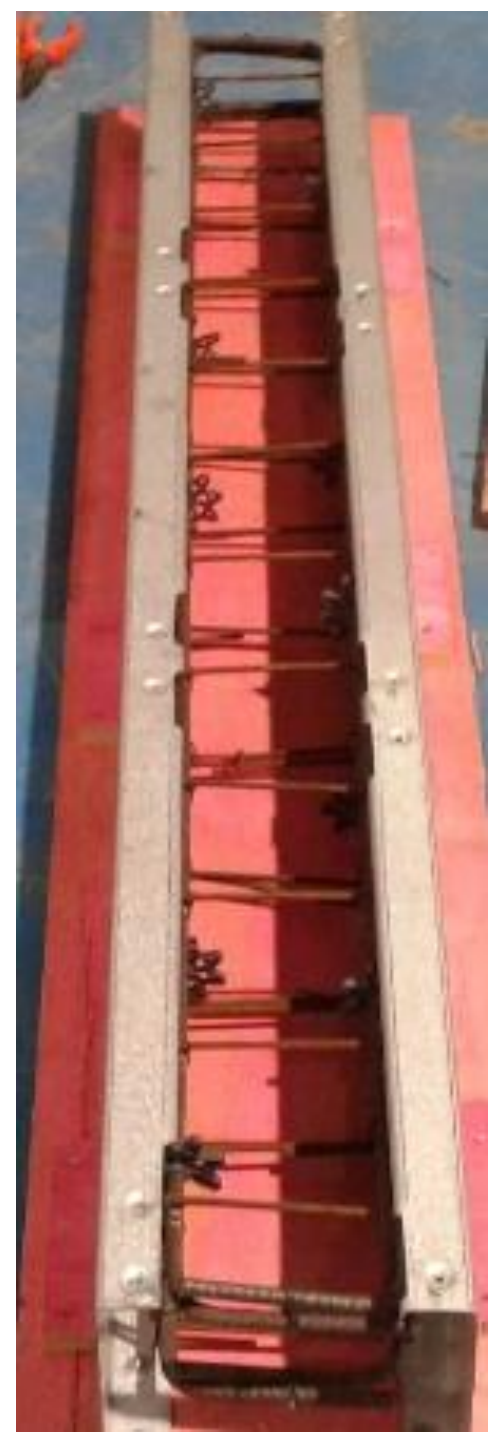

Figura 3.5 - Forma e armadura prontas para a concretagem.

\section{3.}

\section{Propriedades dos materiais}

Como dito anteriormente, as peças ensaiadas são dois pilares e duas colunas de $1,5 \mathrm{~m}$ cada e duas vigas de $4 \mathrm{~m}$ de comprimento, assim chamadas pelo carregamento a que foram submetidas. As colunas foram submetidas à compressão axial, os pilares à flexo-compressão e as vigas à flexão. Esses elementos estruturais possuem a mesma seção transversal, compostos pelos mesmos materiais, aço CA50 para as armaduras longitudinais e CA-60 para as armaduras transversais, concreto dosado para atingir uma resistência característica de $30 \mathrm{MPa}$ e perfis de aço de alta resistência de chapa fina. Nesta seção serão apresentadas as características de cada um destes materiais. 


\subsection{1.}

\section{Concreto}

O concreto utilizado foi produzido no laboratório, dividido em três betonadas e com resistência característica esperada aos 28 dias de 30MPa. O traço utilizado foi 1:2,3:2,4 e o fator água cimento de 0,45. O concreto foi lançado manualmente e o adensamento teve ajuda do vibrador de imersão.

Para caracterização do material, foram colhidos quatro corpos de prova, de $10 \mathrm{~cm}$ de diâmetro e $20 \mathrm{~cm}$ de altura, para cada betonada, seguindo as especificações da ABNT NBR 5738:2015.

Os ensaios de compressão seguiram as especificações da ABNT NBR 5739:2007 e ocorreram no dia do ensaio das peças estruturais com o intuito de obter-se a resistência à compressão mais próxima possível da realidade, Figura 3.6. A partir dos resultados desses ensaios, a resistência característica e o valor adotado nos cálculos para $f_{c k}$ foi igual a 26,5 $\mathrm{MPa}$.

O módulo de elasticidade do concreto adotado foi calculado segundo a ABNT NBR 6118:2014, e o valor encontrado foi $E_{c i}=20,2 \mathrm{GPa}$. Os motivos pelos quais a resistência não atingiu o valor esperado podem ser diversos, desde o controle de umidade dos agregados não ter sido tão rigoroso, o que altera diretamente no traço, até a cura não ter sido feita perfeitamente como recomenda a norma por conta dos fins de semana.

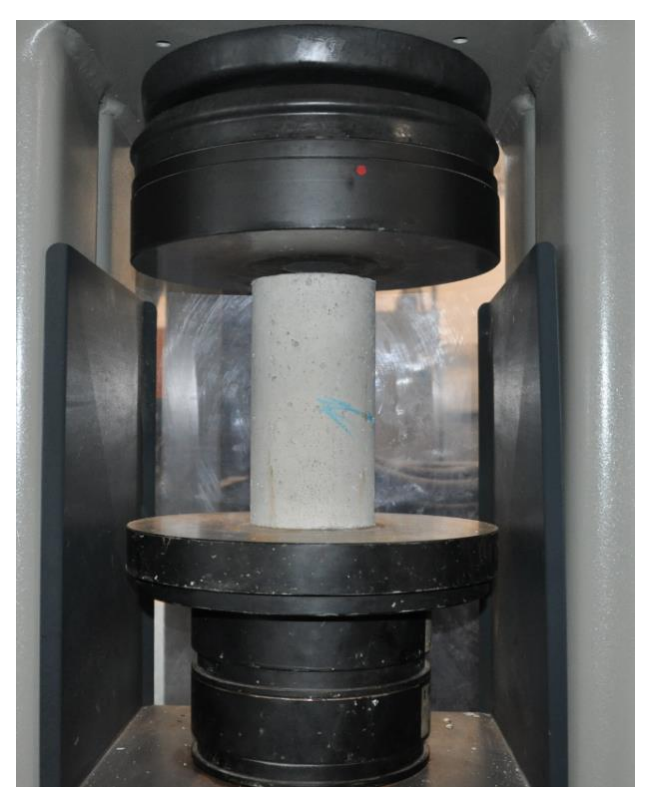

Figura 3.6 - Ensaio de compressão de corpo de prova de concreto. 


\subsection{2.}

\section{Aço das armaduras}

Conforme preconizado na ABNT NBR 7480:2007, a resistência de escoamento de barras e fios de aço pode ser caracterizada por um patamar no diagrama tensão-deformação ou calculada pelo valor da tensão sob carga correspondente à deformação permanente de $0,2 \%$.

Tabela 4 - Resultados dos ensaios de tração do aço das armaduras longitudinais, aço CA-50.

\begin{tabular}{|c|c|c|}
\hline Corpo de prova & $\boldsymbol{f}_{\boldsymbol{y}}(\mathbf{M P a})$ & $\boldsymbol{f}_{\boldsymbol{u}}(\mathbf{M P a})$ \\
\hline $\mathbf{0 1}$ & 509,1 & 652,3 \\
\hline $\mathbf{0 2}$ & 525,8 & 675,0 \\
\hline $\mathbf{0 3}$ & 495,4 & 639,8 \\
\hline $\mathbf{0 4}$ & 481,9 & 648,2 \\
\hline $\mathbf{0 5}$ & 508,4 & 660,5 \\
\hline
\end{tabular}

$\mathrm{Na}$ Tabela 4 são apresentados os valores das tensões de escoamento e ruptura para as barras de aço utilizadas para cinco corpos de prova ensaiados à tração seguindo as prescrições da ABNT NBR ISO 6892-1:2013. Os ensaios foram realizados em um equipamento MTS modelo 311, com capacidade de $1000 \mathrm{kN}$, e instrumentado com um clip gage no meio do vão.

Os resultados obtidos foram dentro do esperado e os valores adotados nos cálculos foram, portanto, $E_{s}=200 \mathrm{GPa}, \boldsymbol{f}_{\boldsymbol{y s}}=500 \mathrm{MPa}$ e $\boldsymbol{f}_{u s}=655 \mathrm{MPa}$.

\subsection{3.}

\section{Aço do Perfil}

Como já mencionado anteriormente, os perfis de aço utilizados neste trabalho formavam uma treliça, que foi desmontada. $\mathrm{O}$ aço utilizado nestes perfis foi fabricado pela Companhia Siderúrgica Nacional (CSN).

Para determinação das propriedades do aço, DALTRO, 2016 ensaiou seis corpos de prova à tração referentes a peças do mesmo lote de treliças utilizado no 
presente trabalho. Os resultados obtidos por DALTRO, 2016 estão apresentados na Tabela 5 e na Figura 3.7.

A partir desses resultados é possível observar que o aço não apresentou alongamento superior a $10 \%$, nem a relação entre resistência à ruptura e a resistência ao escoamento, $f_{u} / f_{y}$, maior ou igual a 1,08 , critérios abordados na ABNT NBR 14762:2010. A AISI S100 (2012) sugere neste caso que a tensão limite de escoamento adotada seja determinada pelo menor valor entre $0,75 f_{y}$ e $410 \mathrm{MPa}$. Logo, a tensão limite de escoamento adotada deve ser 410MPa. O módulo de elasticidade longitudinal, $E$, utilizado nos cálculos, segundo a ABNT NBR 14762:2010, igual a $200 \mathrm{GPa}$.

Tabela 5 - Resultados dos ensaios de caracterização do aço do perfil (DALTRO, 2016).

\begin{tabular}{|c|c|c|c|c|}
\hline $\begin{array}{c}\text { Corpo de } \\
\text { prova }\end{array}$ & $\boldsymbol{f}_{\boldsymbol{y}}(\mathbf{M P a})$ & $\boldsymbol{f}_{\boldsymbol{u}}(\mathbf{M P a})$ & $\boldsymbol{f}_{\boldsymbol{u}} / \boldsymbol{f}_{\boldsymbol{y}}$ & $\begin{array}{c}\text { Alongamento } \\
\text { após a } \\
\text { ruptura }\end{array}$ \\
\hline $\mathbf{0 1}$ & 610,70 & 620,81 & 1,02 & $3,47 \%$ \\
\hline $\mathbf{0 2}$ & 597,50 & 612,57 & 1,03 & $1,87 \%$ \\
\hline $\mathbf{0 3}$ & 602,10 & 614,56 & 1,02 & $3,21 \%$ \\
\hline $\mathbf{0 4}$ & 612,80 & 623,20 & 1,02 & $2,46 \%$ \\
\hline $\mathbf{0 5}$ & 621,80 & 630,88 & 1,01 & $3,54 \%$ \\
\hline $\mathbf{0 6}$ & 623,30 & 639,90 & 1,03 & $3,26 \%$ \\
\hline
\end{tabular}




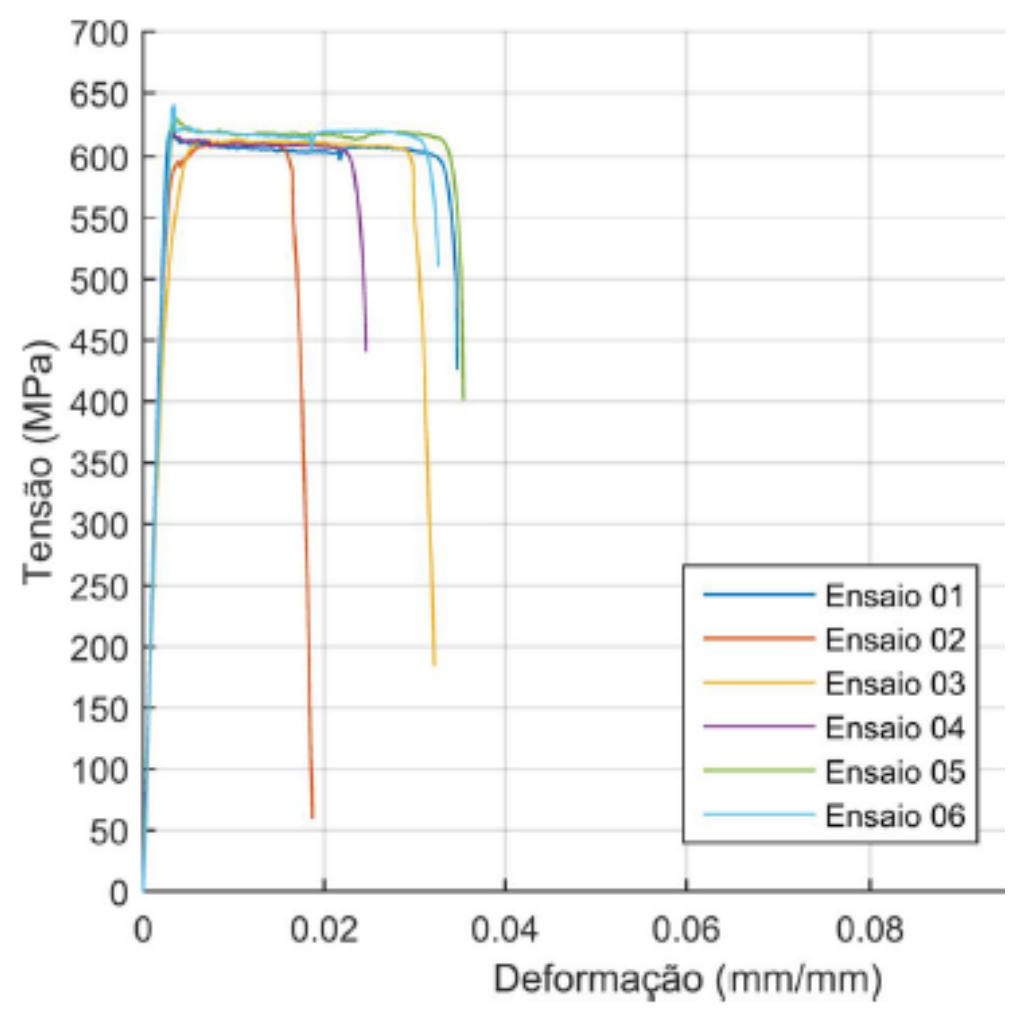

Figura 3.7 - Gráfico de tensão versus deformação dos ensaios de caracterização do aço. (DALTRO, 2016).

\section{4. Descrição dos ensaios}

Neste item apresenta-se como cada ensaio foi montado e realizado, a instrumentação e equipamentos utilizados, bem como a forma como o carregamento foi aplicado.

\subsection{1.}

\section{Ensaios de compressão}

As peças ensaiadas à compressão axial serão chamadas de colunas. Conforme a Figura 3.10, a coluna foi colocada na posição de ensaio sobre um conjunto de apoio que restringe deslocamento em uma direção e sob uma rótula universal para compor um sistema bi apoiado. A célula de carga de $2000 \mathrm{kN}$, devidamente calibrada, foi colocada abaixo do atuador hidráulico de $2000 \mathrm{kN}$ de capacidade, o qual é acionado manualmente por uma bomba de dupla ação.

A instrumentação, se deu por quatro transdutores de deslocamento, um em cada face da coluna, Figura 3.8 e Figura 3.9. As leituras dos transdutores e da célula 
de carga eram obtidas automaticamente por meio de um programa de aquisição de dados.

O carregamento foi aplicado de forma lenta. Como o atuador era acionado manualmente, a cada $100 \mathrm{kN}$ era feira uma pausa de 30 segundos sem aplicação de mais carga. Em seguida aplicava-se mais $100 \mathrm{kN}$. Esse processo foi repetido sucessivamente até a ruptura da peça.

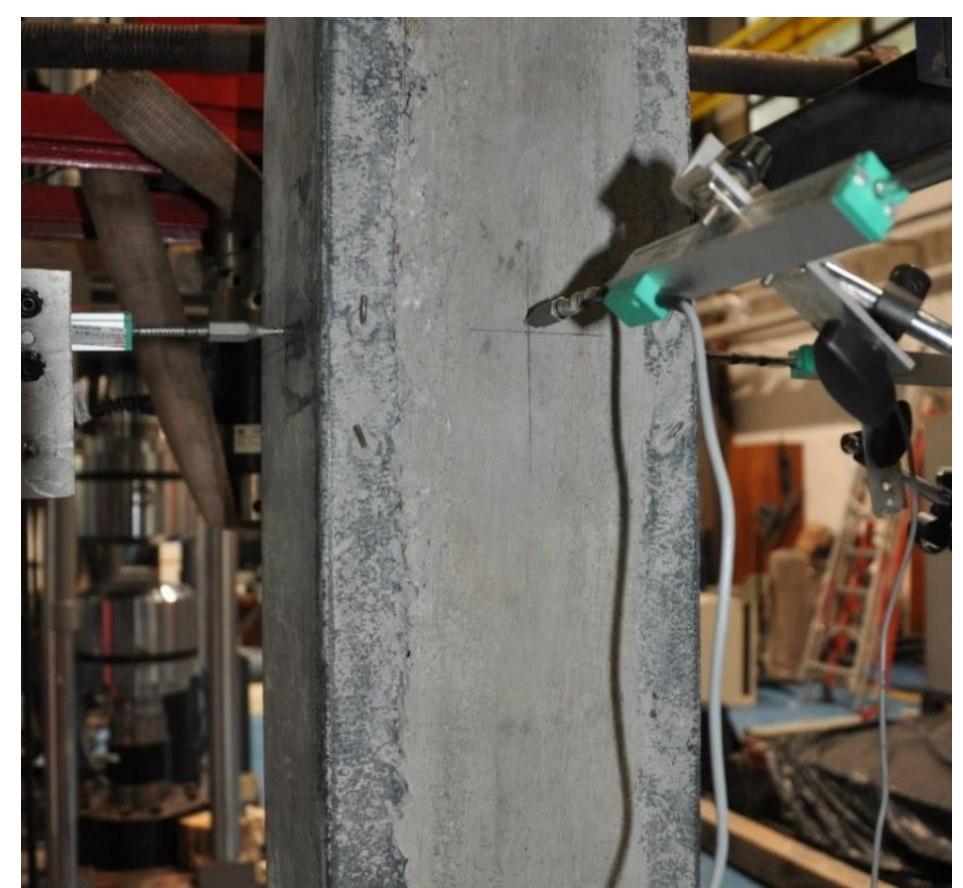

Figura 3.8 - Instrumentação com transdutores de deslocamento na seção central da coluna.

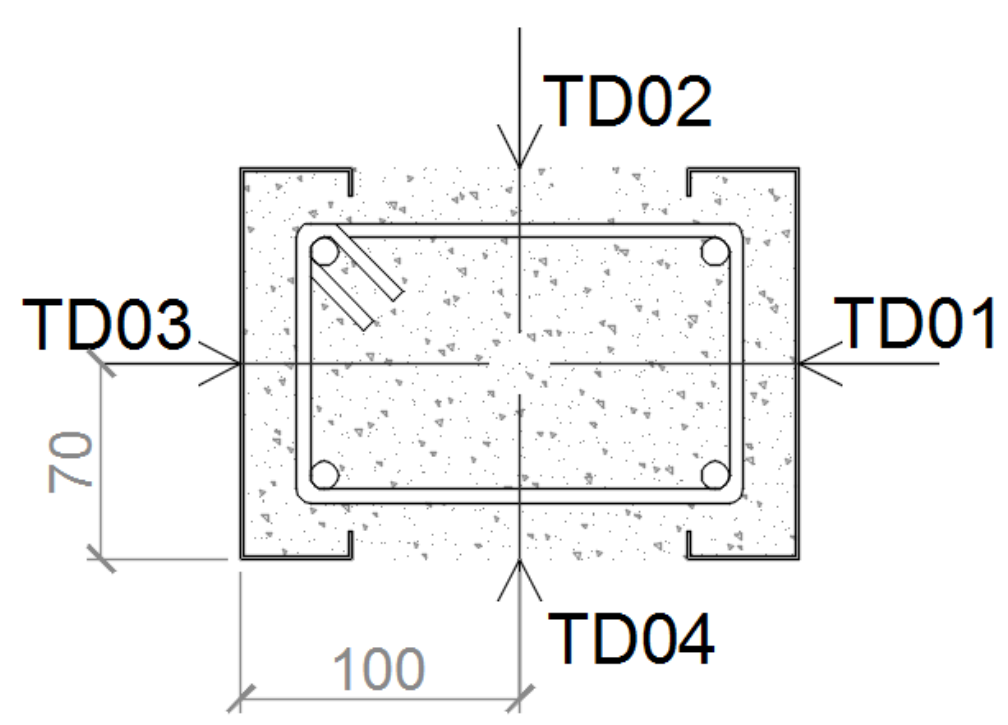

Figura 3.9- Posição dos transdutores na seção central da peça, dimensões em $\mathrm{mm}$. 


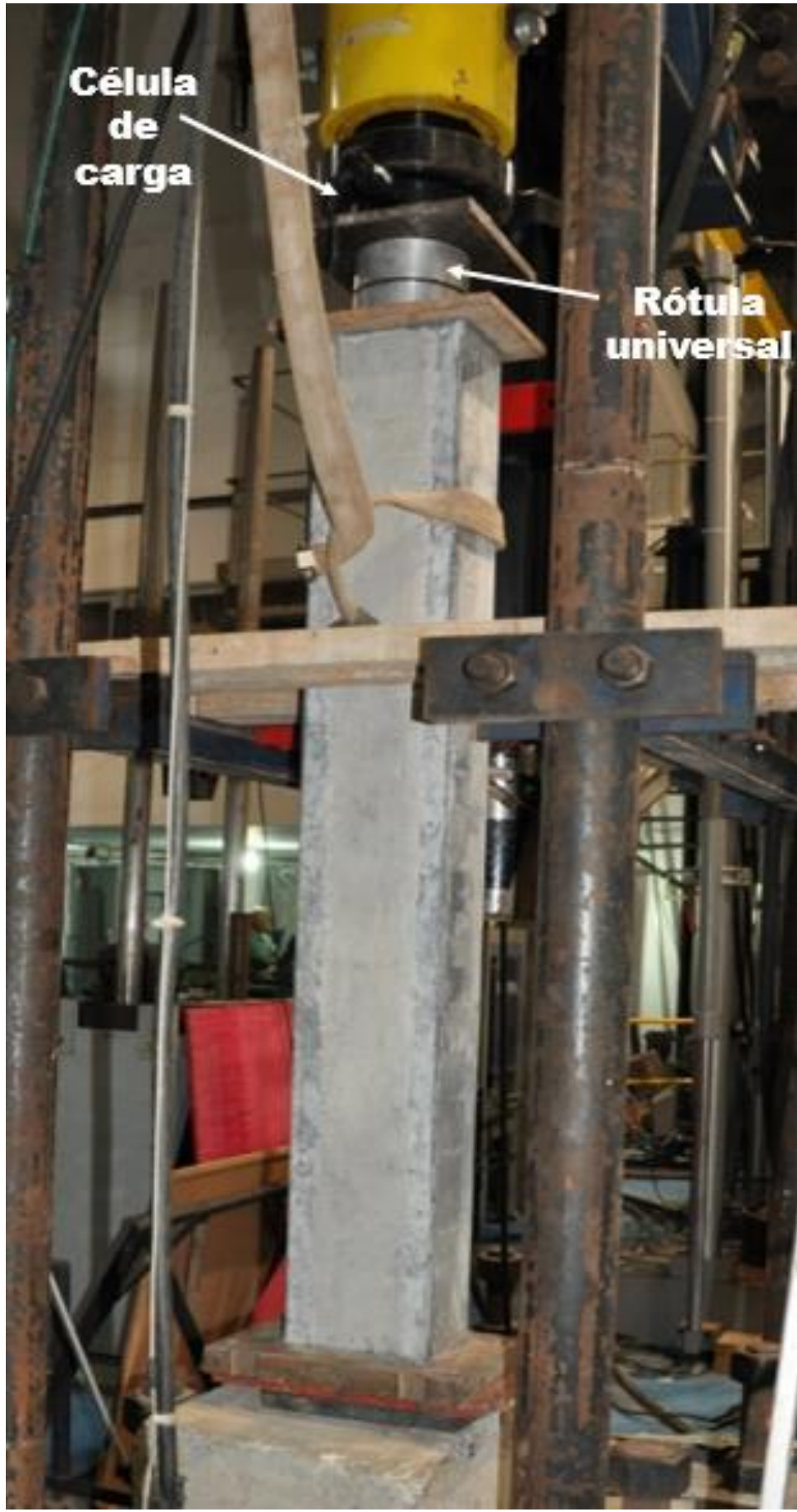

Figura 3.10 - Ensaio de compressão axial.

\subsection{2.}

\section{Ensaios de flexão}

As vigas ensaiadas foram posicionadas com uma extremidade sobre um apoio de primeiro gênero e outra sobre um apoio de segundo gênero, como visto na Figura 3.11. Logo as vigas foram testadas na configuração simplesmente apoiada. O carregamento foi aplicado por atuador servo hidráulico MTS modelo $244.41 \mathrm{com}$ 
capacidade de $500 \mathrm{kN}$. Com o auxílio de rótulas e um perfil de aço, a carga foi aplicada na viga em dois pontos, como mostrado na Figura 3.13.

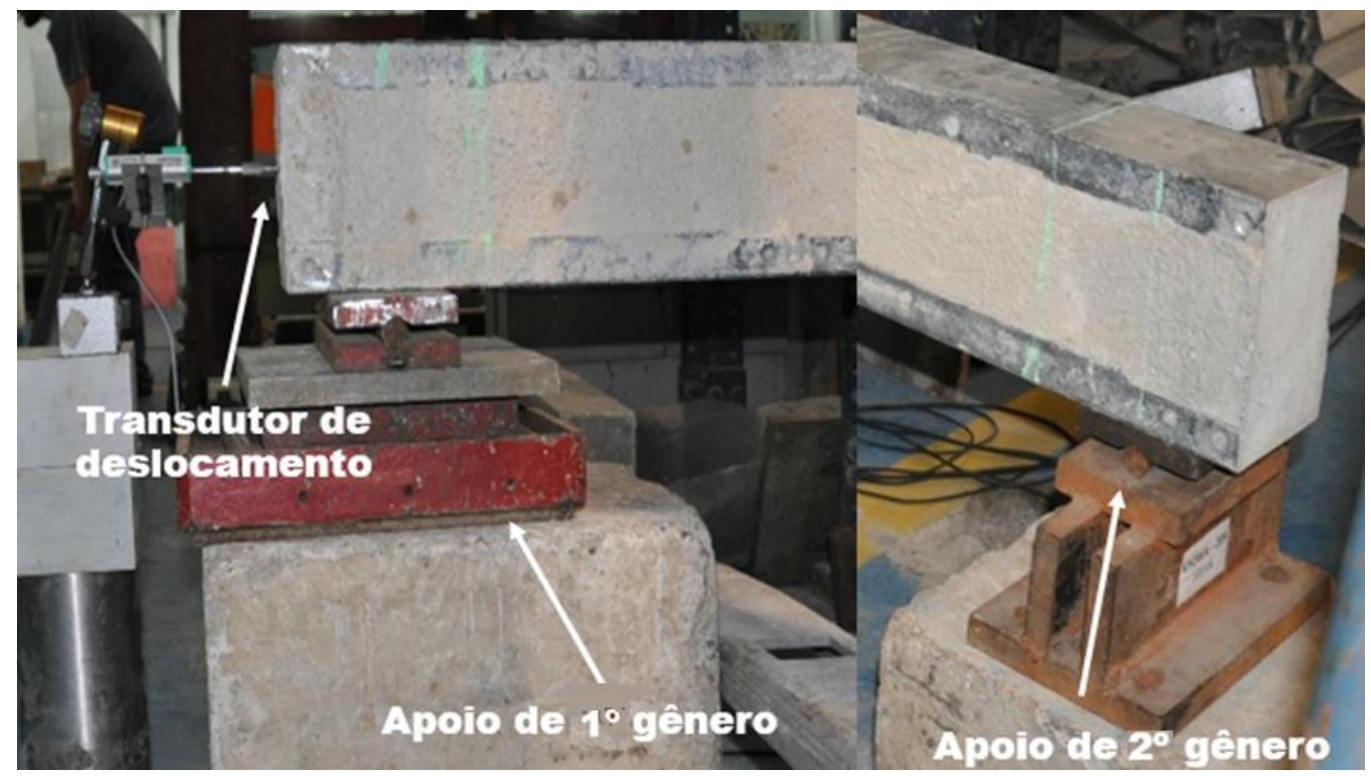

Figura 3.11 - Apoios dos ensaios das vigas.

Na Figura 3.12 observa-se um esquema indicando o carregamento e as distâncias entre cargas e apoios das vigas ensaiadas. Neste modelo, cada força $P$ representa metade da carga aplicada pelo atuador somada a metade do peso próprio da viga auxiliar, e a carga $q$ representa o peso próprio da viga distribuído em todo o seu comprimento.

A instrumentação foi feita com quatro transdutores de deslocamento. Um estava posicionado na face extrema do lado esquerdo, junto do apoio de primeiro gênero para observar o deslocamento horizontal da peça. Os outros três foram posicionados na face inferior da viga, na direção da aplicação da carga e no meio do vão. As leituras eram obtidas automaticamente por meio de um programa de aquisição de dados.

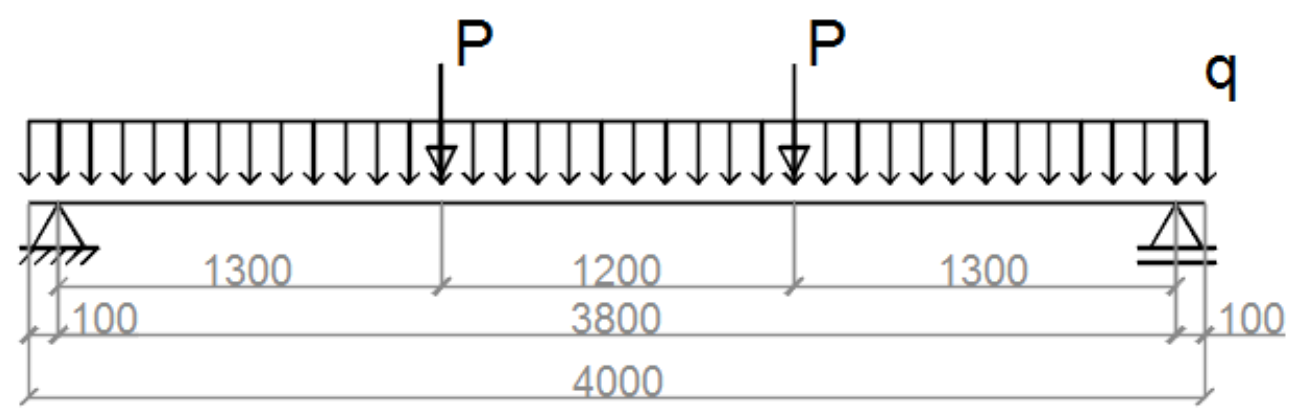

Figura 3.12 - Representação do carregamento das vigas e suas respectivas distâncias em mm. 
Anteriormente ao carregamento, fez-se uma ciclagem de carga, numa frequência de $1 \mathrm{~Hz}$, com 5000 ciclos no total, variando a carga entre 5\% da carga última calculada e $40 \%$ da mesma para a acomodação do sistema. Ao final dos ciclos a carga foi aplicada de 5\% em 5\% da carga última calculada com uma pausa entre esses estágios de carregamento.

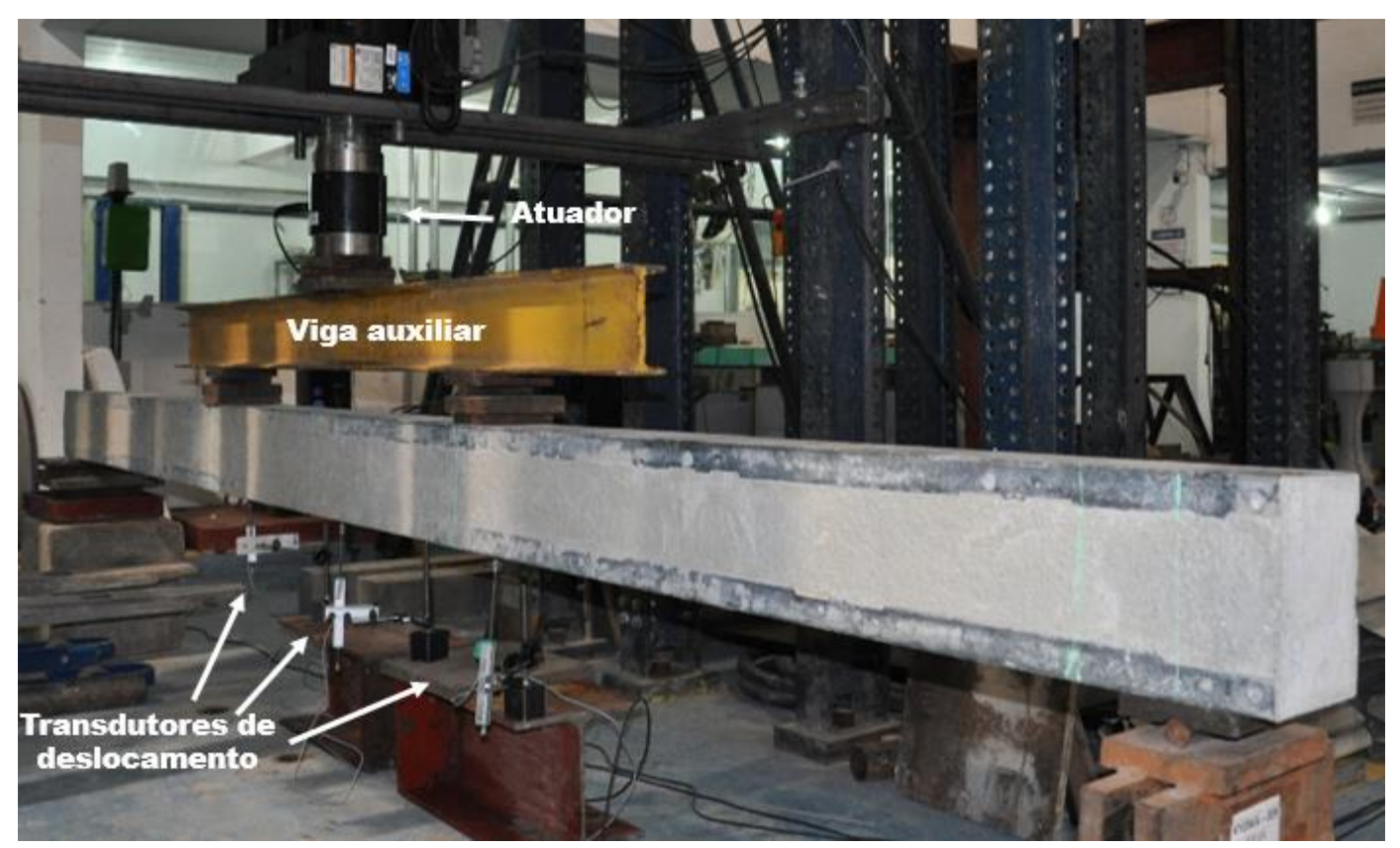

Figura 3.13 - Sistema dos ensaios 3 e 4 com viga auxiliar para carregamento em dois pontos.

\subsection{3. \\ Ensaios de flexo-compressão}

Os últimos ensaios foram montados e instrumentados da mesma maneira que as peças ensaiadas à compressão, a diferença entre eles foi a presença da excentricidade no carregamento, de $40 \mathrm{~mm}$, o que pode ser notado na Figura 3.14. Os corpos de prova submetidos à compressão com excentricidade de carregamento foram denominadas pilares. 


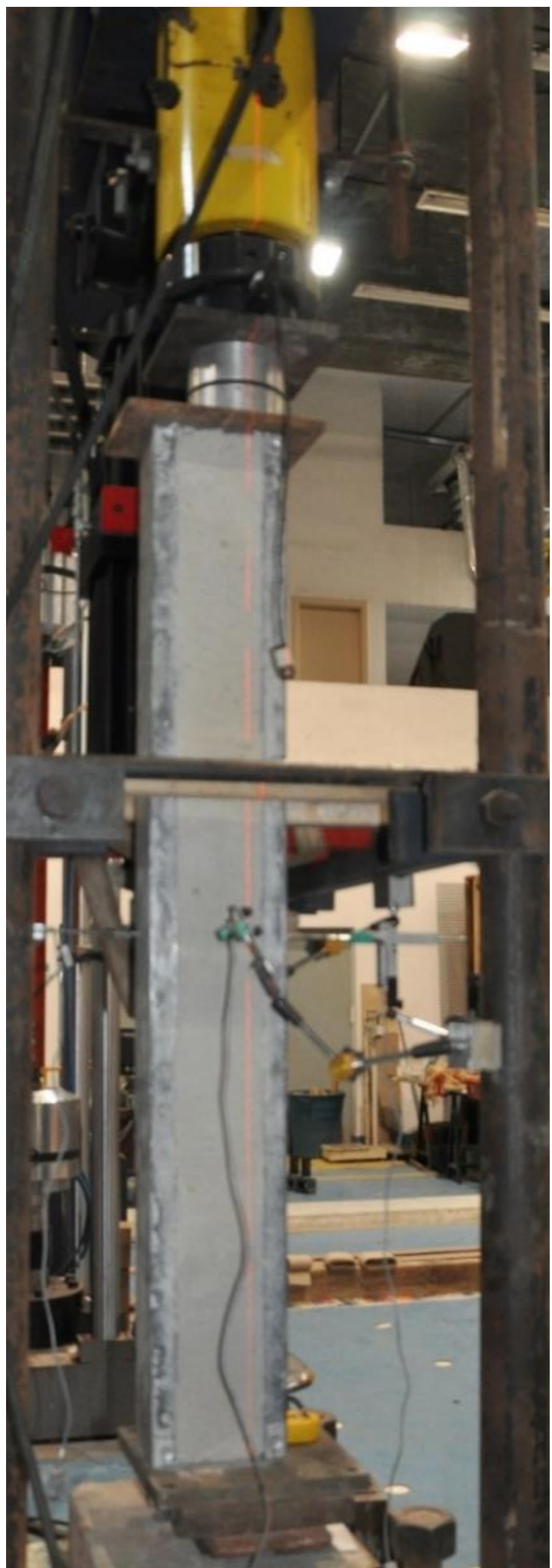

Figura 3.14 - Ensaio com excentricidade no carregamento 


\section{4 \\ Resultados experimentais}

\section{1.}

\section{Considerações iniciais}

Neste capítulo serão apresentados os resultados obtidos a partir dos ensaios realizados em laboratório, conforme programa experimental descrito no capítulo anterior. As análises destes resultados serão expostas no capítulo seguinte. Vale ressaltar que as dimensões das peças foram verificadas antes de serem ensaiadas e foram encontradas diferenças de até $5 \%$, para mais ou para menos, entre o valor desejado e a dimensão real da peça.

\section{2.}

\section{Ensaios de compressão}

Os ensaios de compressão axial, como já foram descritos no capítulo anterior, foram realizados em peças de $1,5 \mathrm{~m}$ de comprimento. Esse comprimento foi determinado devido ao limite da altura disponível no pórtico utilizado para os ensaios e o falta de tempo e recursos para a suspensão desse pórtico para ensaios com comprimentos maiores.

Os dados obtidos por meio do ensaio da primeira coluna foram força aplicada, tempo e deslocamentos laterais, a partir dos transdutores posicionados conforme Figura 3.9. A partir desses dados foram plotados gráficos de força normal aplicada versus deslocamento lateral para cada coluna.

A Figura 4.1 apresenta o gráfico feito a partir dos dados dos transdutores de deslocamento TD02 e TD04, e a Figura 4.2 exibe o gráfico feito a partir dos dados dos transdutores de deslocamento TD01 e TD03, relacionados com a força normal aplicada, para a Coluna 01.

Como é possível observar na Figura 4.1 e na Figura 4.2, os gráficos apresentam ruídos, uma vez que, o carregamento foi aplicado manualmente a partir da bomba de dupla ação, a qual acionava o atuador hidráulico. 


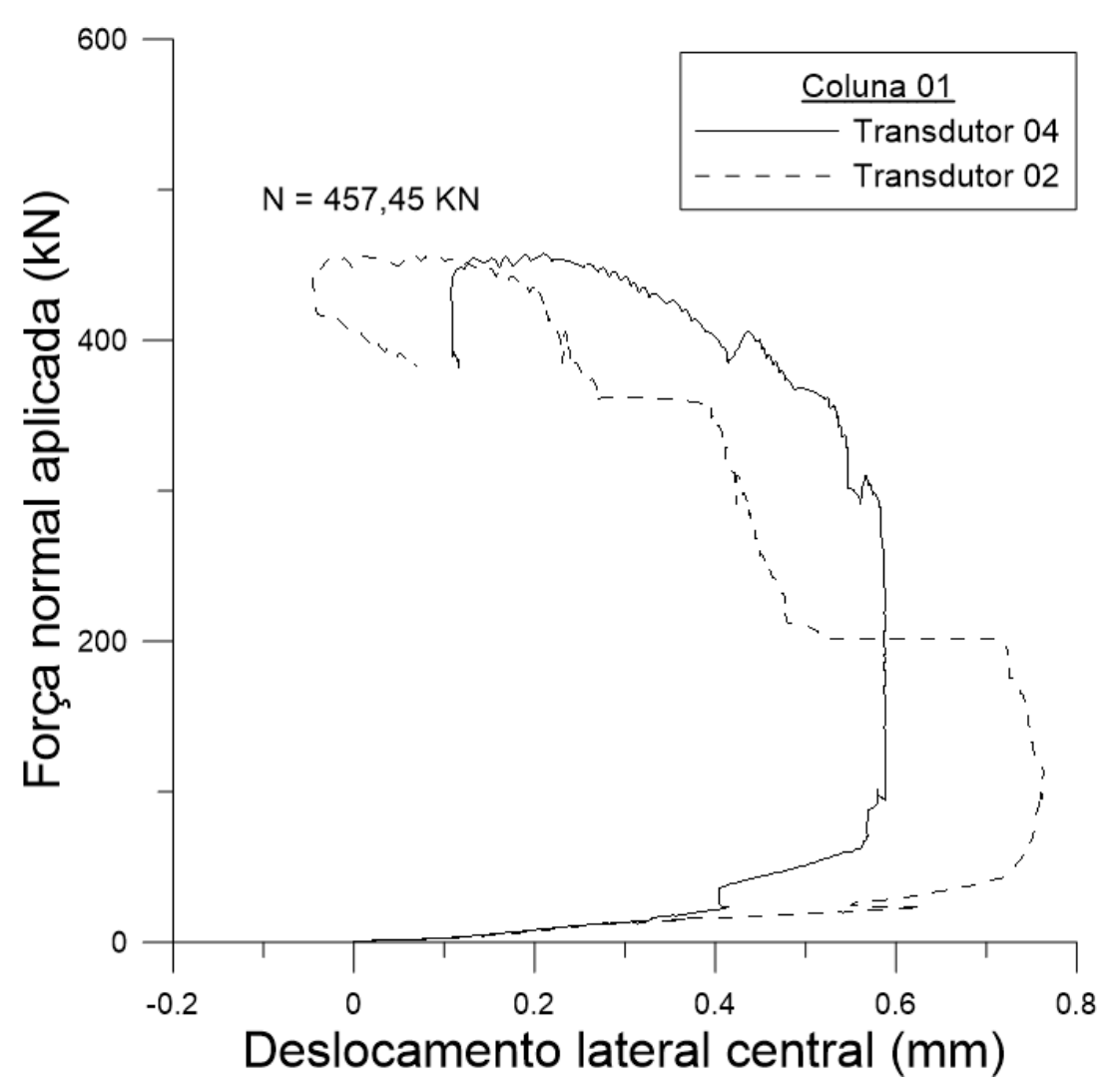

Figura 4.1 - Gráfico força normal aplicada x deslocamento lateral, transdutores TD02 e TD04, da Coluna 01.

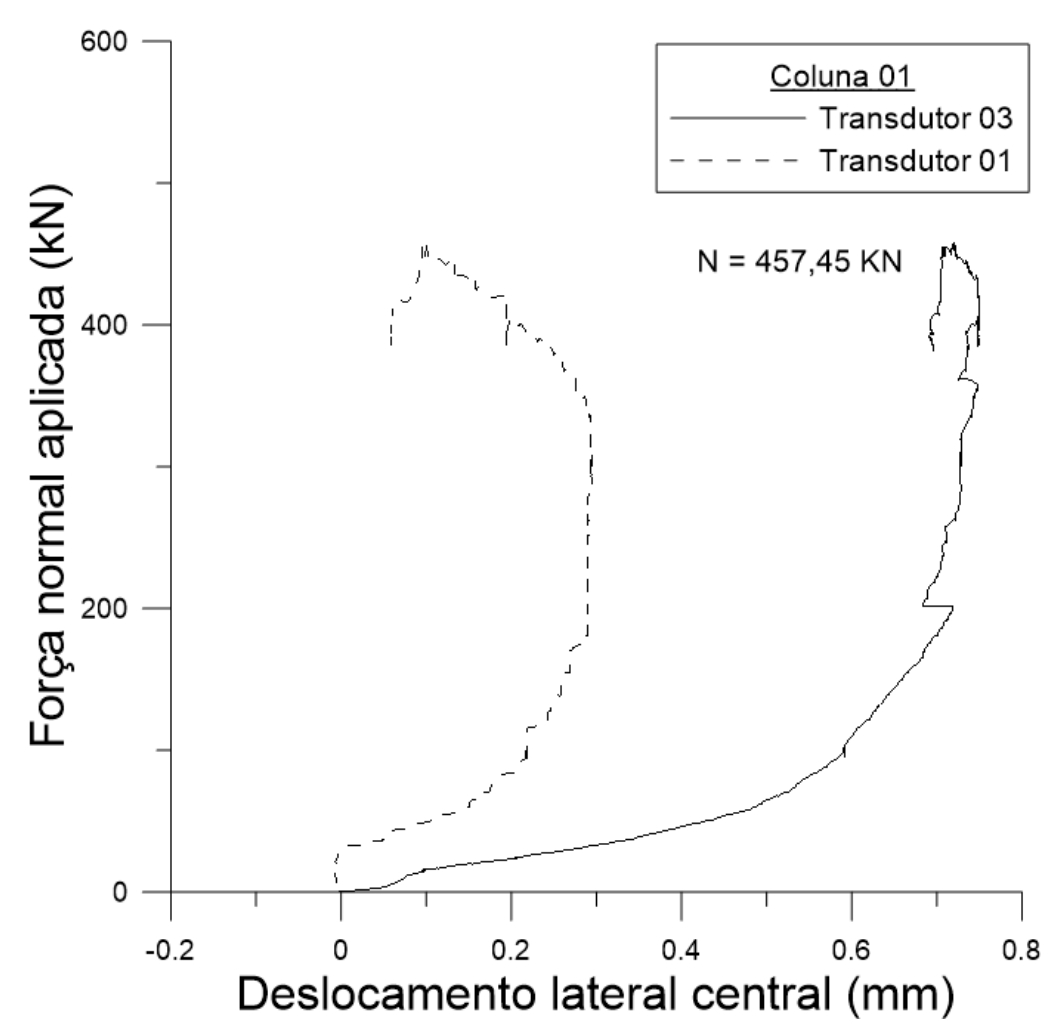

Figura 4.2 - Gráfico força normal aplicada x deslocamento lateral, transdutores TD01 e TD03, da Coluna 01. 


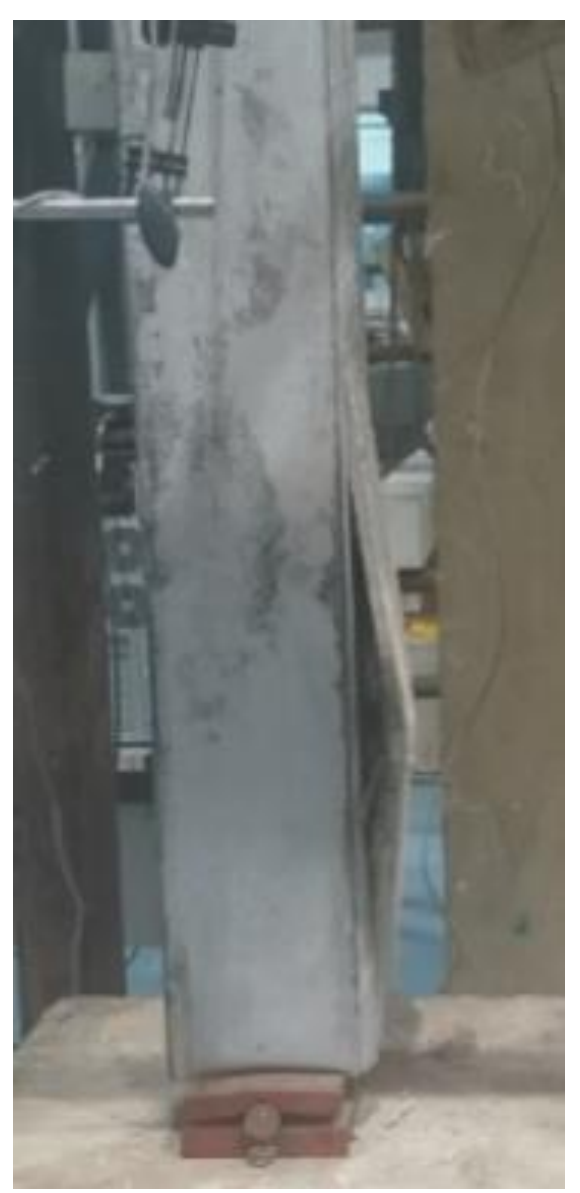

Figura 4.3 - Coluna 01 após ensaio.

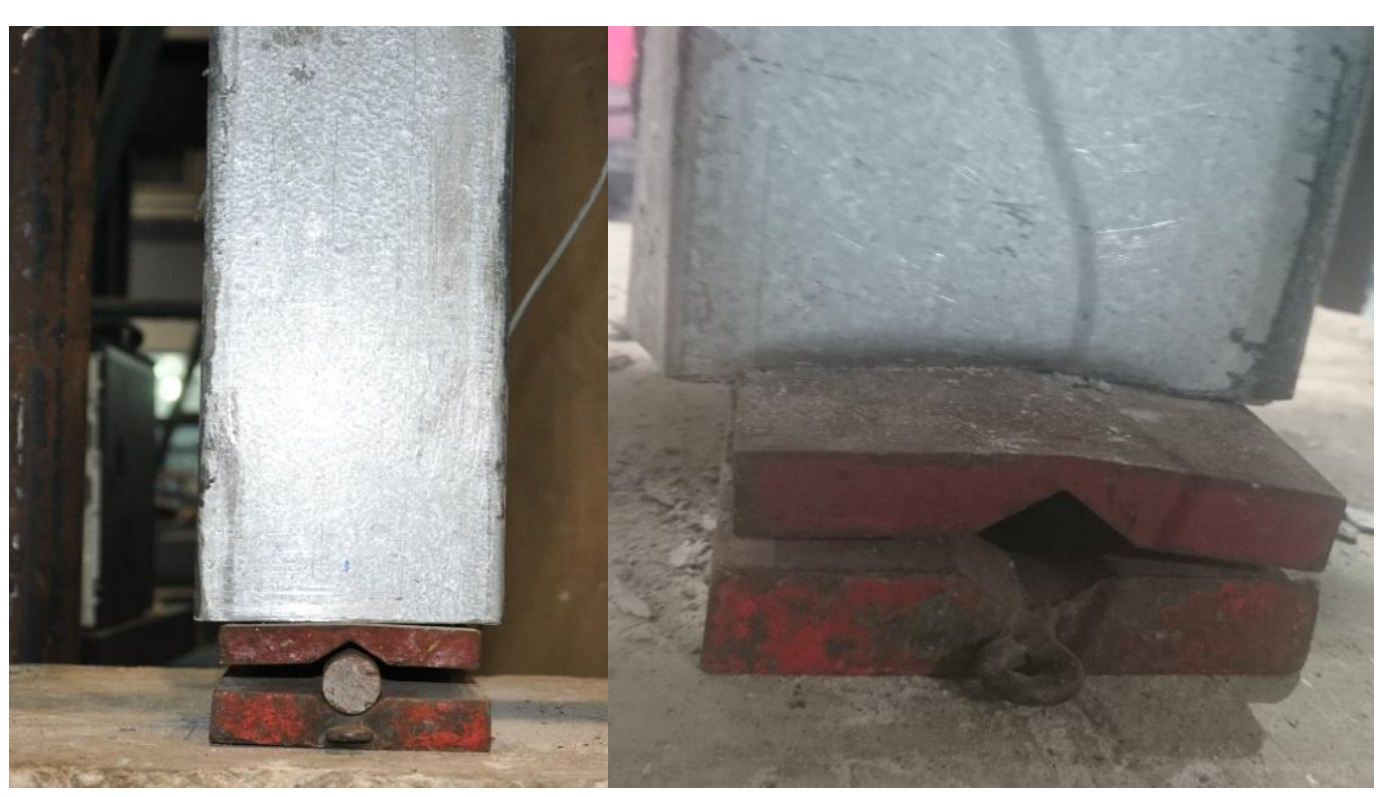

Figura 4.4 - Apoio da Coluna 01 antes e após o ensaio.

O ensaio foi interrompido quando houve o desplacamento do concreto, e uma queda abrupta de carga indicada pela célula de carga. A carga normal referente à 
ruína da Coluna 01 foi de 457,5 kN. Na Figura 4.3 fica evidente tanto esse esmagamento quanto o desplacamento do concreto.

$\mathrm{Na}$ Figura 4.4 é exibido em detalhe o apoio da coluna e o esmagamento do perfil na região do apoio. Isso ocorreu pela má distribuição de carga ao longo da base da coluna, uma vez que a chapa do apoio não tinha contato com toda a superfície da base da coluna.

Para evitar o esmagamento do perfil observado na base da Coluna 01, no ensaio da Coluna 02 colocou-se uma chapa de aço maior que a base da coluna para garantir o contato de toda a superfície da base da coluna com o sistema de apoio.

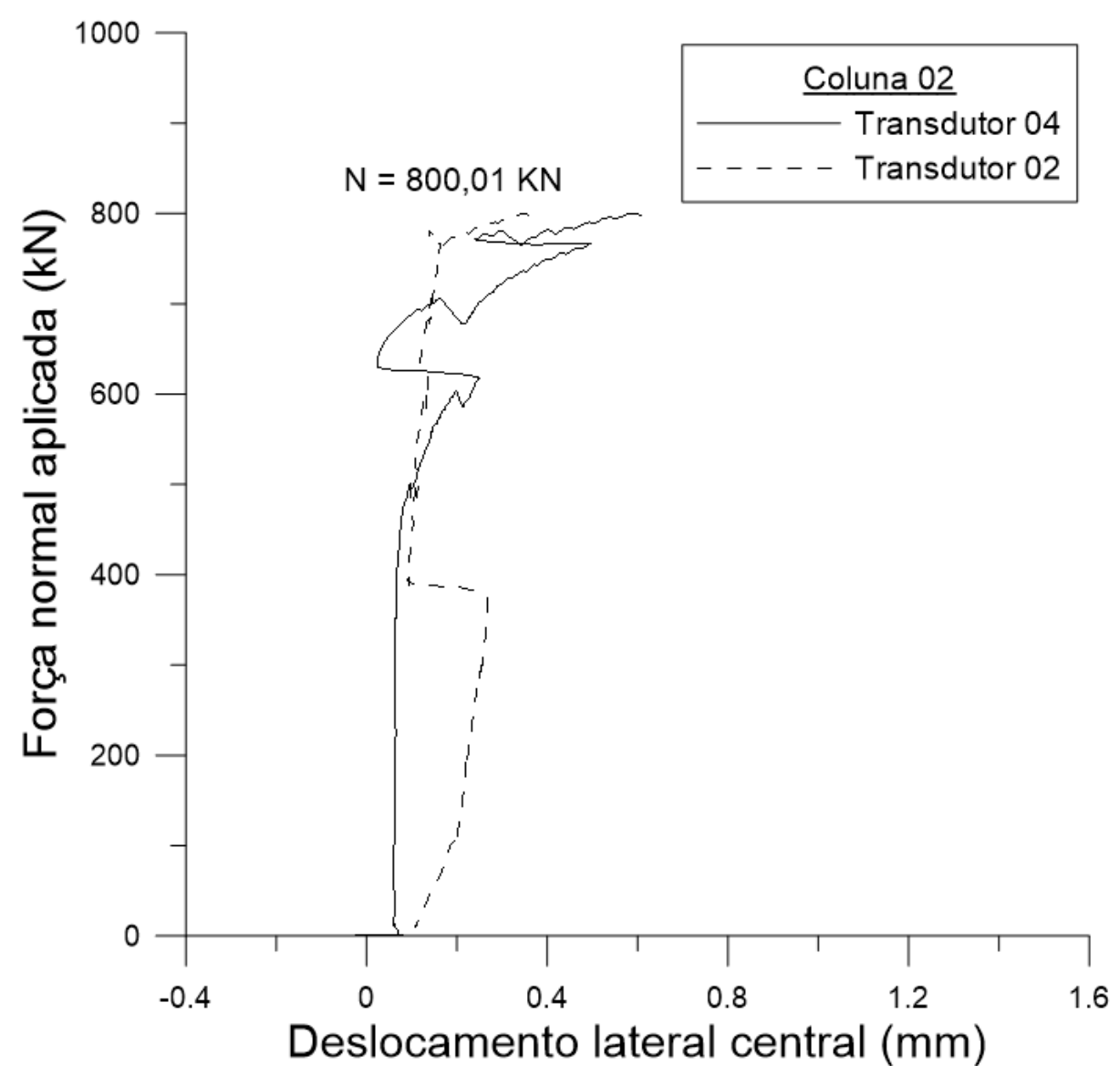

Figura 4.5 - Gráfico força normal aplicada x deslocamento lateral, TD02 e TD04, da Coluna 02. 


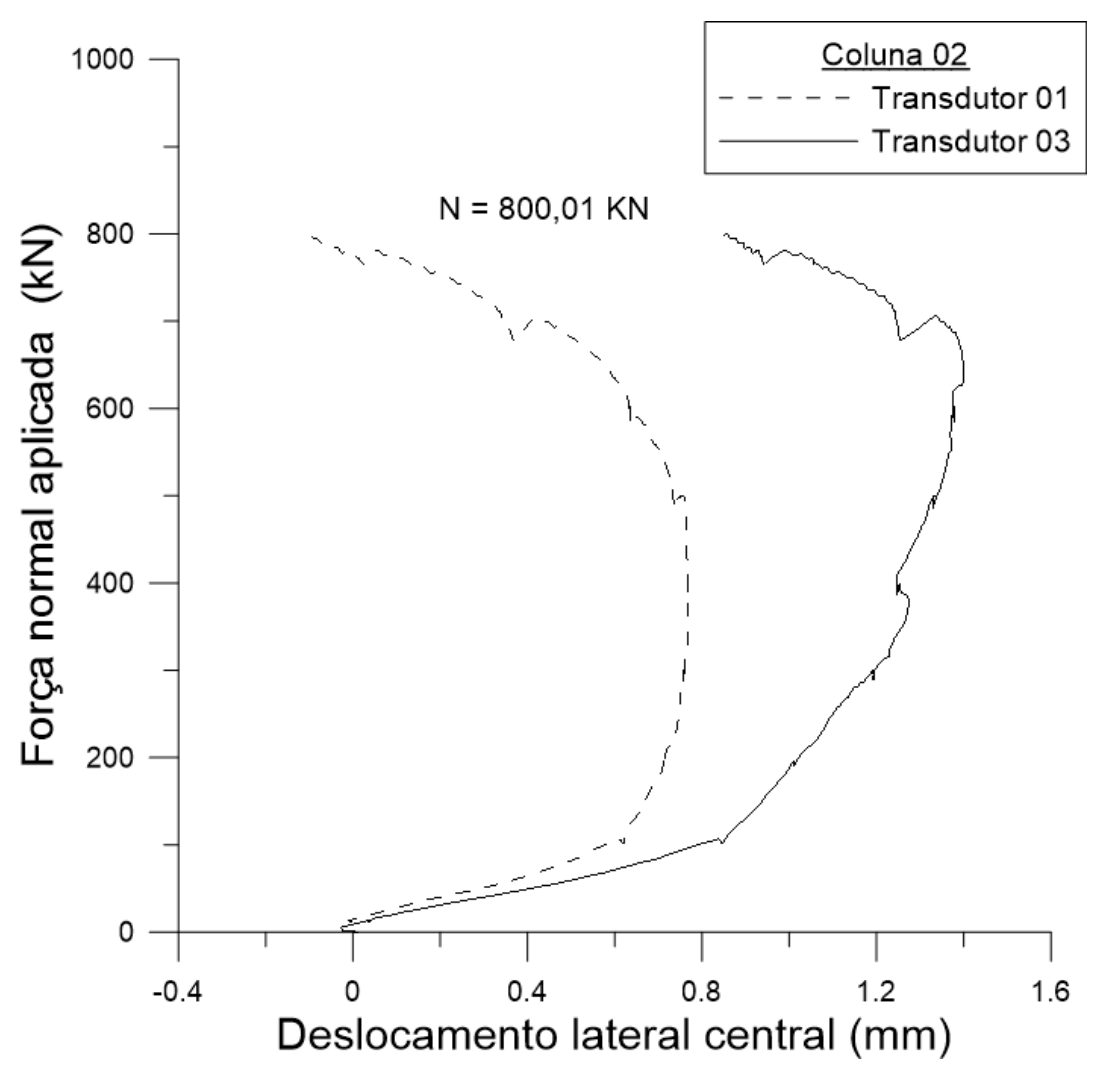

Figura 4.6 - Gráfico força normal aplicada x deslocamento lateral, TD01 e TD03, da Coluna 02.

De forma semelhante ao teste da Coluna 01, os resultados obtidos com o ensaio da Coluna 02 estão apresentados em dois gráficos, Figura 4.5 e Figura 4.6, de força normal aplicada versus deslocamento lateral referentes aos transdutores posicionados na seção central da coluna conforme a Figura 3.9.

É possível observar nas Figura 4.5 e Figura 4.6, que os gráficos apresentam ruídos devido ao fato do carregamento ter sido aplicado manualmente.

Assim como no ensaio da Coluna 01, o ensaio foi interrompido quando ocorreu uma queda brusca de carga devido ao desplacamento do concreto, na face onde o transdutor TD02 está posicionado, ver Figura 4.7. A carga aplicada referente à ruína da Coluna 02 foi de $800,0 \mathrm{kN}$. 


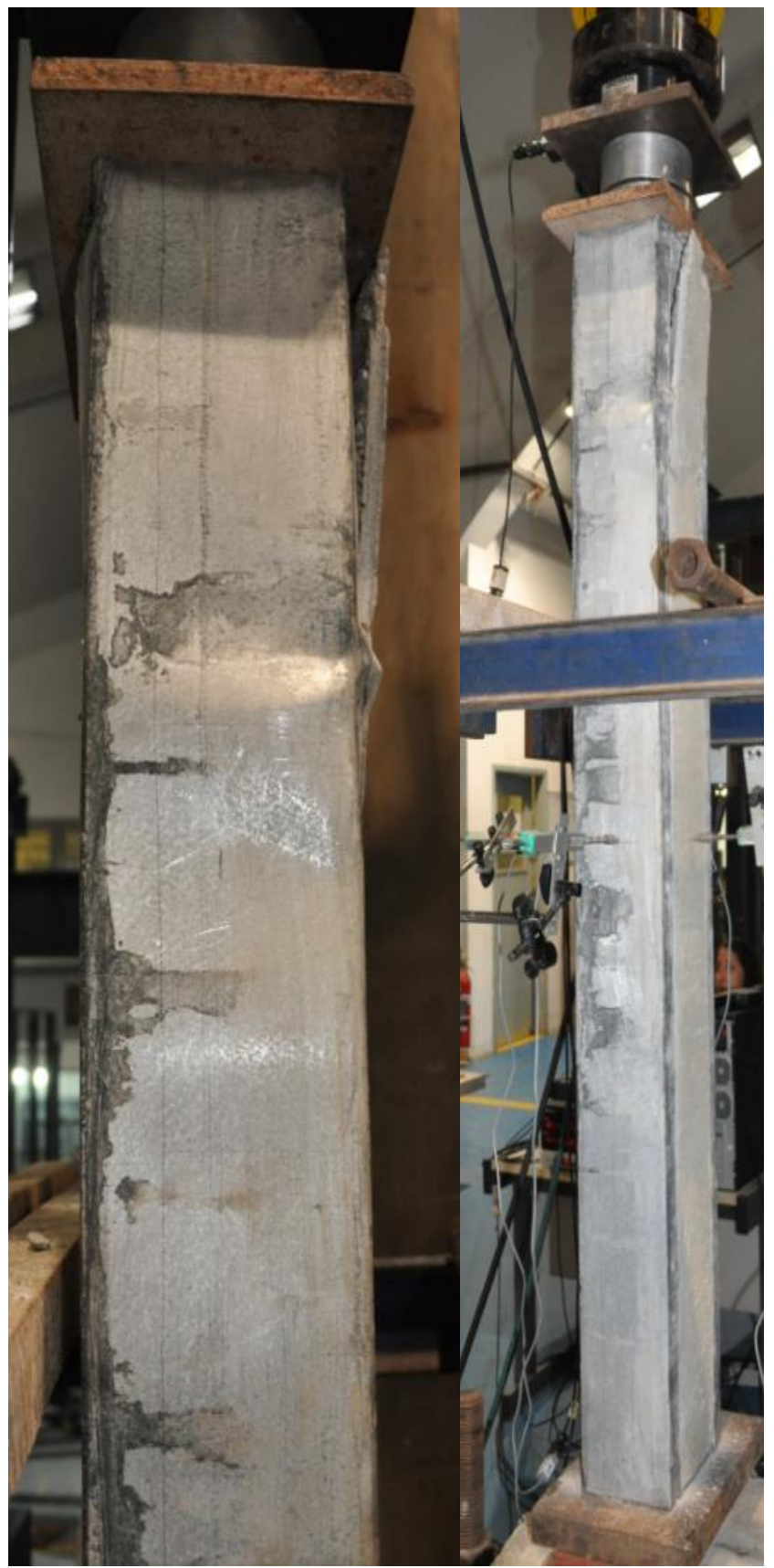

Figura 4.7 - Coluna 02 ensaiada.

\section{3.}

\section{Ensaios de flexão}

Os ensaios das vigas foram interrompidos quando o deslocamento no meio do vão atingiu $76 \mathrm{~mm}$, o que corresponde L/50, onde L é o comprimento do vão, 3,8m. Conforme recomendação do Euroode 4, 2004, quando a carga de ruína supera a carga que leva o deslocamento máximo ao valor de L/50 deve-se adotar como carga de ruína a carga que proporciona este deslocamento. Os resultados experimentais das Viga 01 e Viga 02 foram bem próximos, como é possível 
observar na Figura 4.8, a qual apresenta o gráfico de momento aplicado versus deslocamento do transdutor localizado no centro do vão.

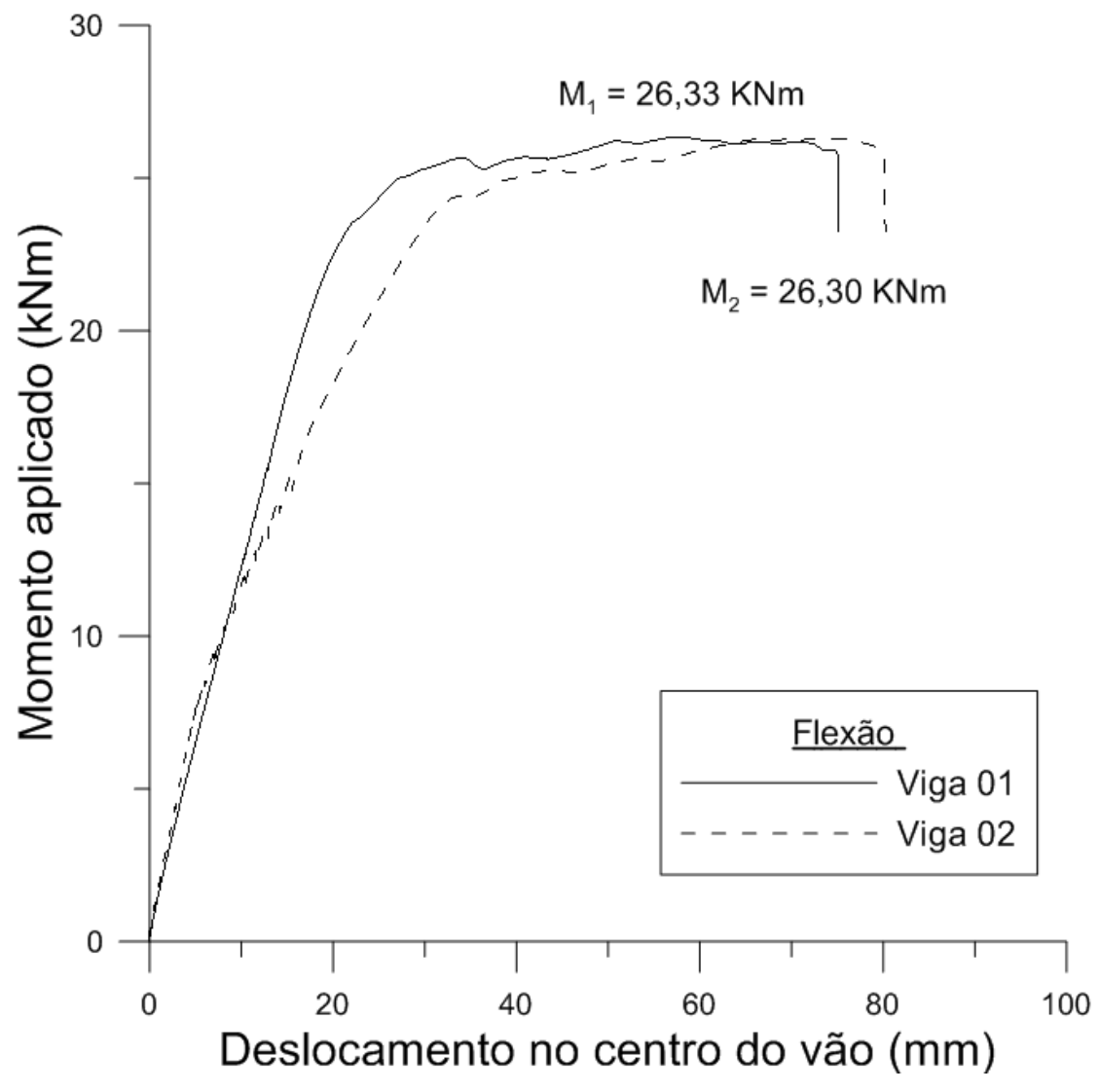

Figura 4.8 - Gráfico momento aplicado x deslocamento no centro do vão das Viga 01 e Viga 02.

Para atingir o deslocamento de $L / 50$, aplicou-se, através do atuador 40,5 kN na Viga 01 e na Viga 02, ou 26,3 kNm de momento central. A Figura 4.9 apresenta a configuração da viga com o carregamento aplicado, e mostra a viga auxiliar, amarela, a qual dividiu o carregamento em dois pontos de aplicação. Foi possível observar após os ensaios que houve o escorregamento entre os materiais nas extremidades das vigas. 


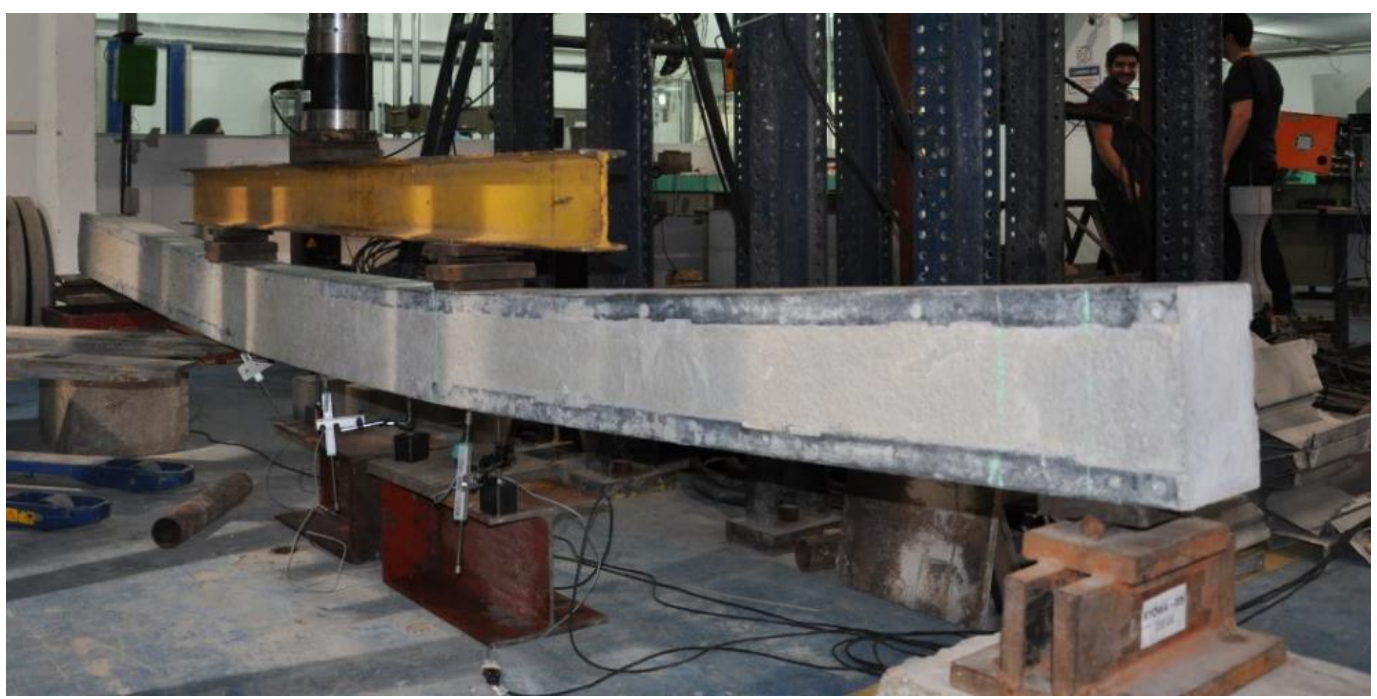

Figura 4.9 - Viga 01 durante o ensaio.

\section{4. \\ Ensaios de flexo-compressão}

Os ensaios dos pilares foram realizados aplicando-se a força normal com uma excentricidade de $40 \mathrm{~mm}$. O ponto $P$ da Figura 4.10 representa o ponto de aplicação da carga. A figura mostra ainda o posicionamento dos transdutores de deslocamento, TD01 e TD03 posicionados no eixo forte e TD02 e TD04 no fraco.

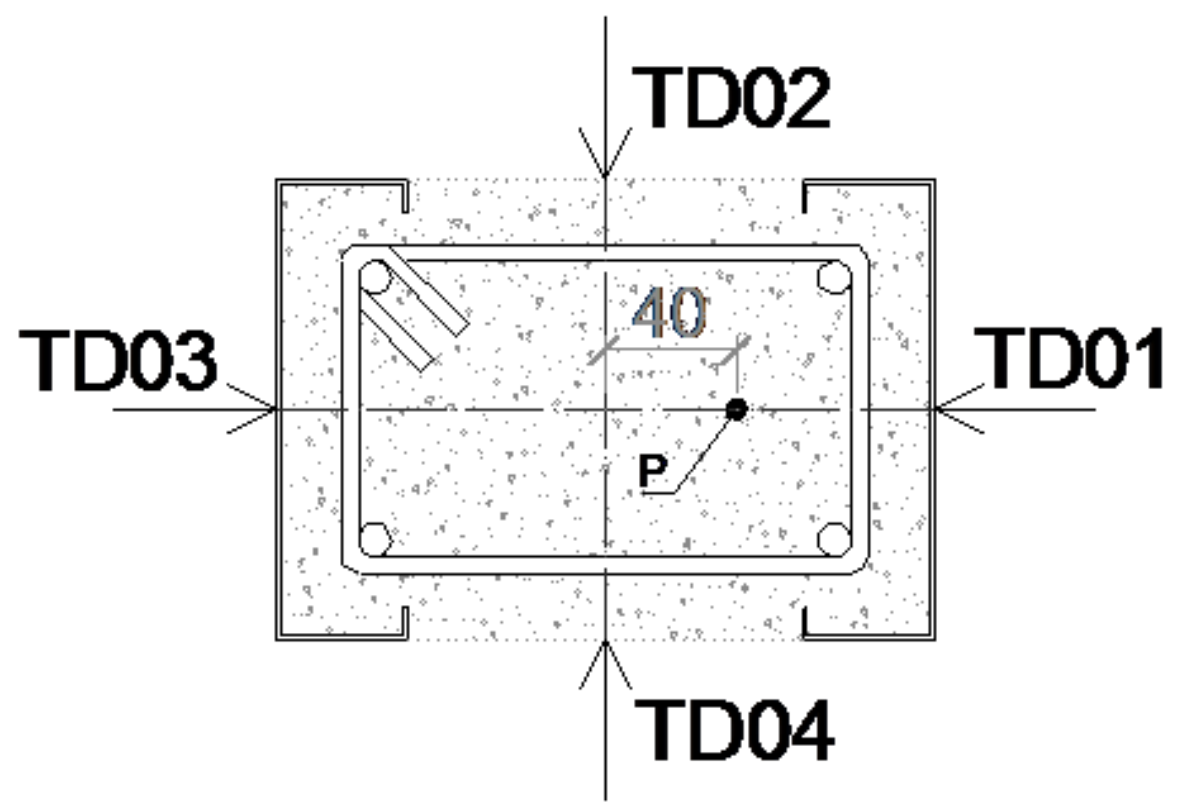

Figura 4.10 - Posição dos transdutores na seção central do pilar e do ponto de aplicação de carga em relação aos eixos da peça.

A Figura 4.12 exibe o gráfico força normal aplicada versus deslocamento lateral dado pelos dois transdutores TD02 e TD04, do Pilar 01 durante o ensaio. De 
maneira análoga a Figura 4.13 apresenta o gráfico que relaciona a força normal aplicada na peça com os deslocamentos obtidos por meio dos transdutores TD01 e TD03, posicionados conforme indicado pela Figura 4.10.

A carga de ruína do Pilar 01 foi de 613,7 kN. Observa-se na Figura 4.11 a base do pilar após o ensaio, no qual a ruptura do concreto levou o pilar à ruína.

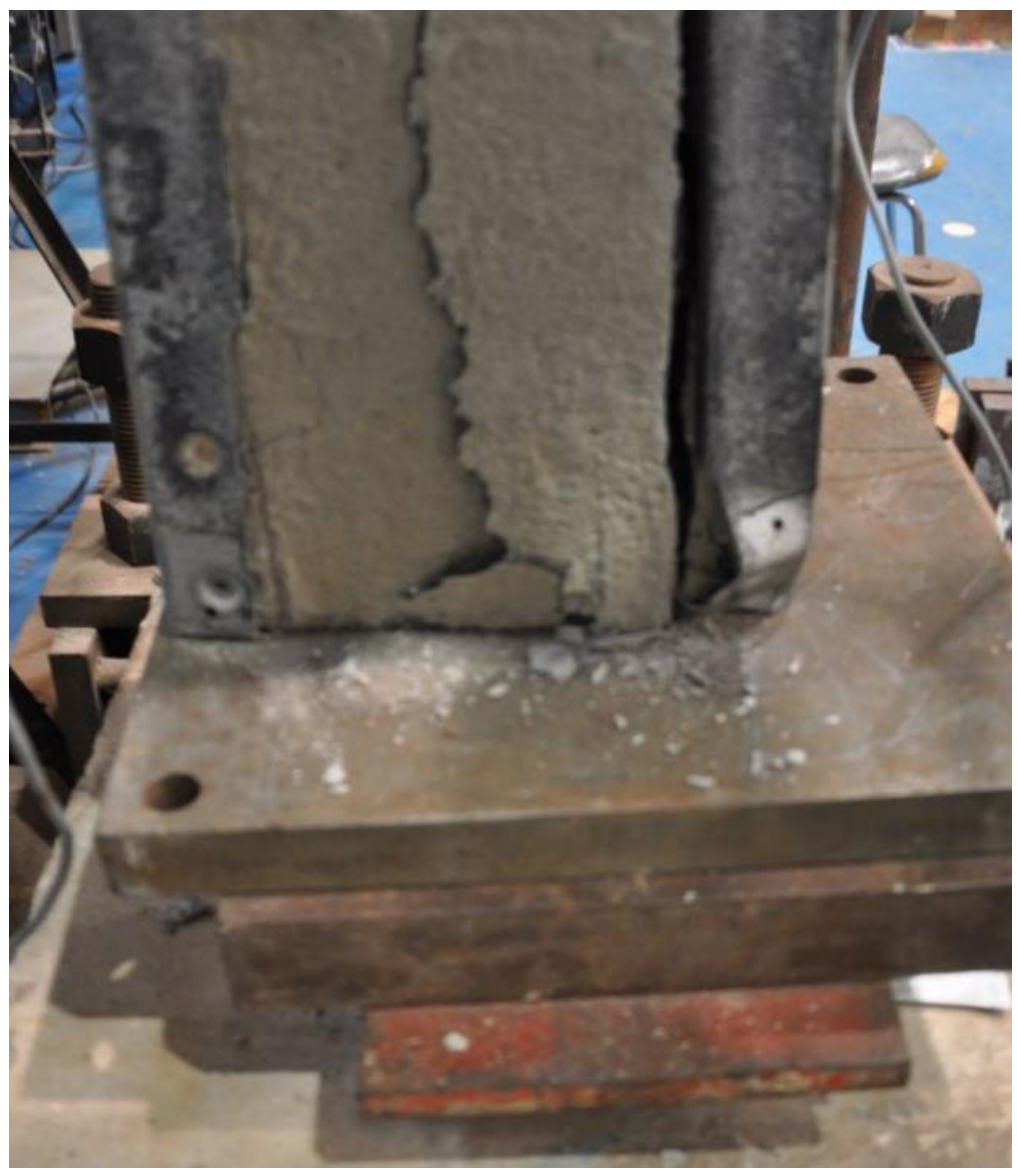

Figura 4.11 - Pilar 01 após o ensaio de compressão excêntrica. 


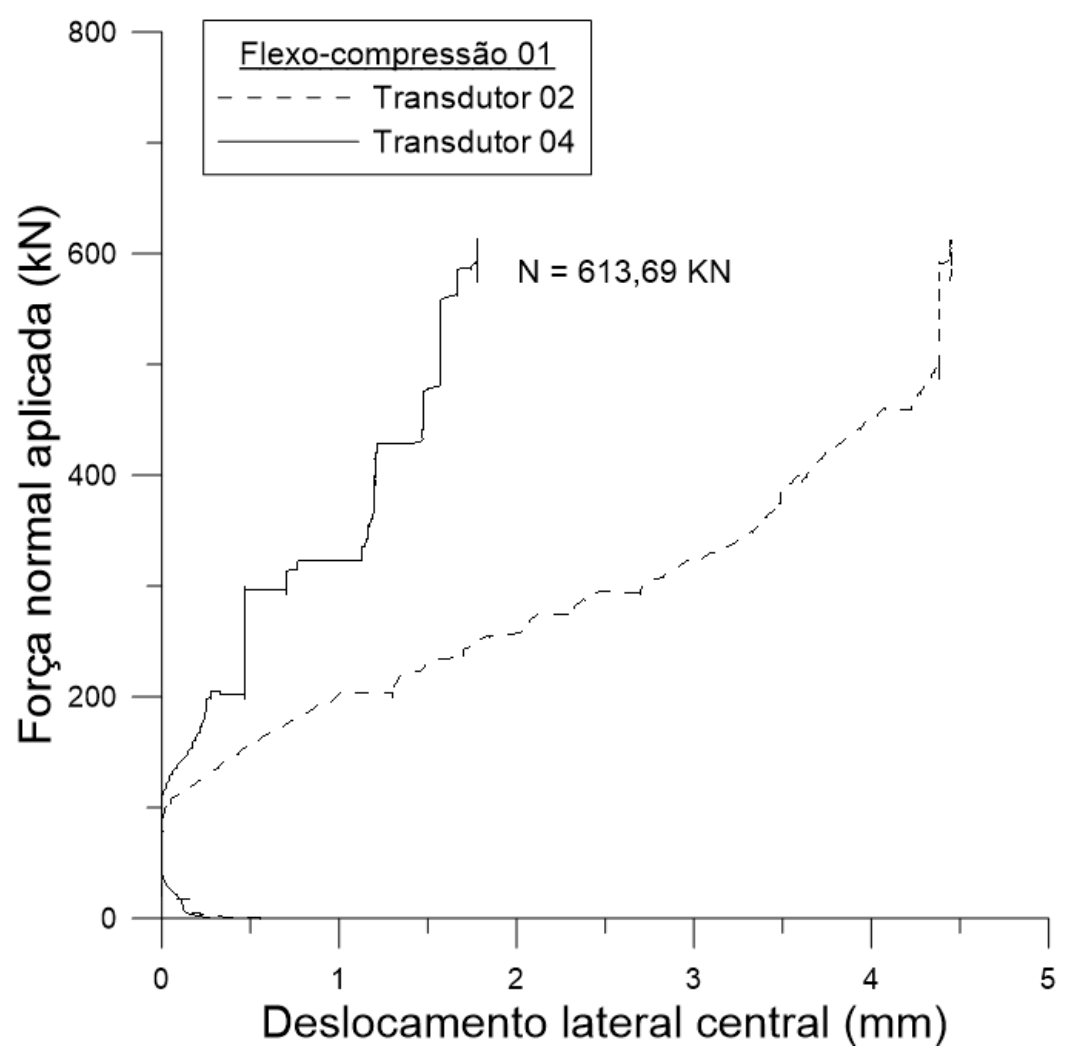

Figura 4.12 - Gráfico força normal aplicada x deslocamento lateral, transdutores TD02 e TD04, Pilar 01.

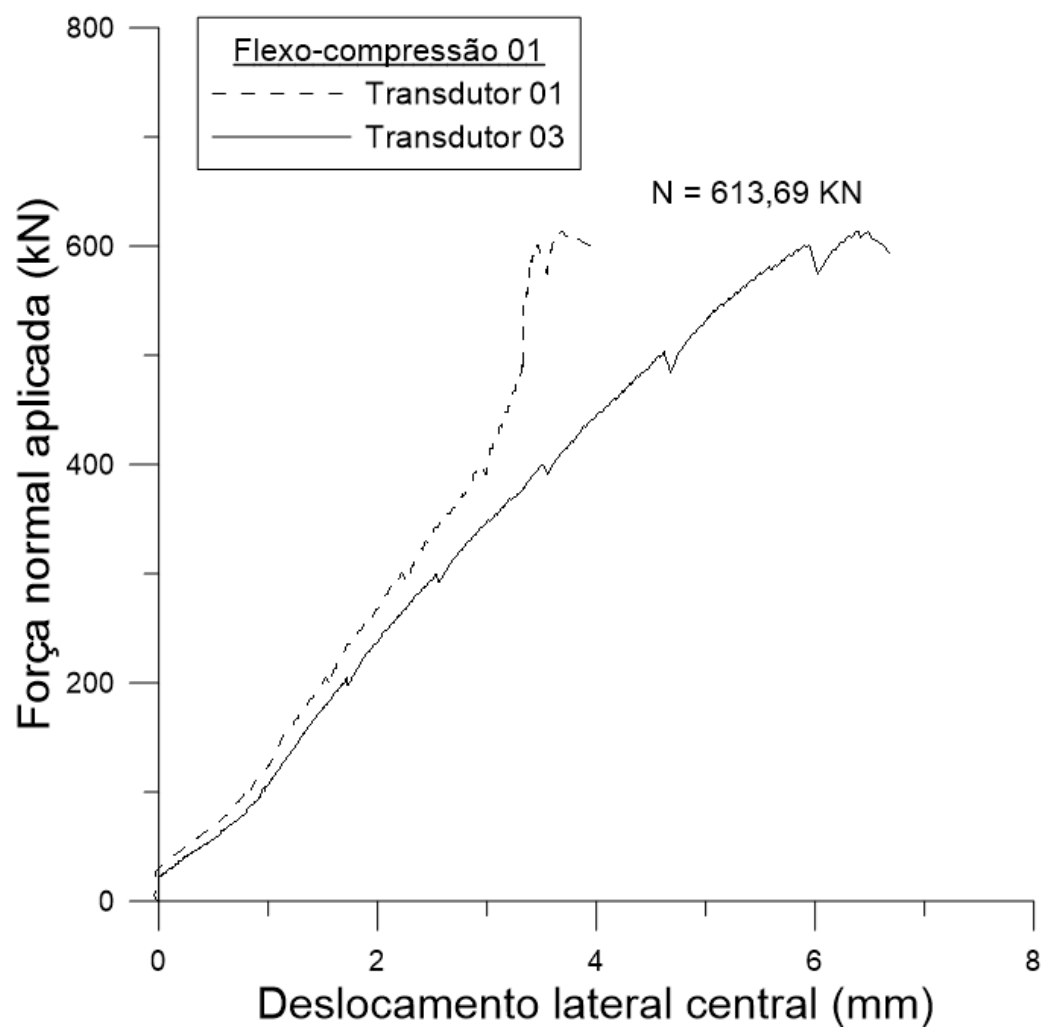

Figura 4.13 - Gráfico força normal aplicada x deslocamento lateral, transdutores TD01 e TD03, do Pilar 01. 
Com os resultados do ensaio do Pilar 02 pode-se plotar os gráficos força normal aplicada versus deslocamento lateral apresentados nas Figura 4.16 e Figura 4.17. A Figura 4.15 apresenta o pilar 02 após o ensaio, onde o deslocamento provocado pela ruptura do concreto danificou o perfil, levando o pilar à ruptura com a carga aplicada de 526,1 kN. Na Figura 4.14 é apresentado em detalhe a ruptura desse pilar.

De maneira semelhante aos gráficos referentes aos ensaios das colunas, os gráficos referentes aos ensaios dos pilares apresentam ruídos, isso deve-se ao fato do carregamento ter sido aplicado manualmente como mencionado no programa experimental, do capítulo 3.

É importante observar que os deslocamentos dados pelos transdutores posicionados no concreto são menores que os dados pelos transdutores localizados nos perfis de aço.

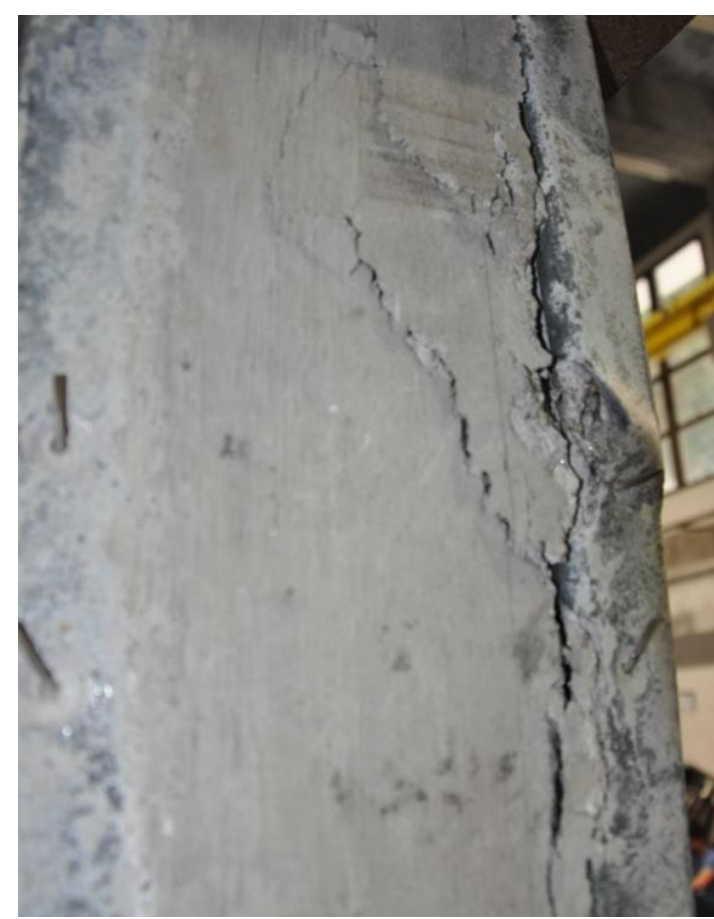

Figura 4.14 - Detalhe da ruptura do concreto do Pilar 02. 


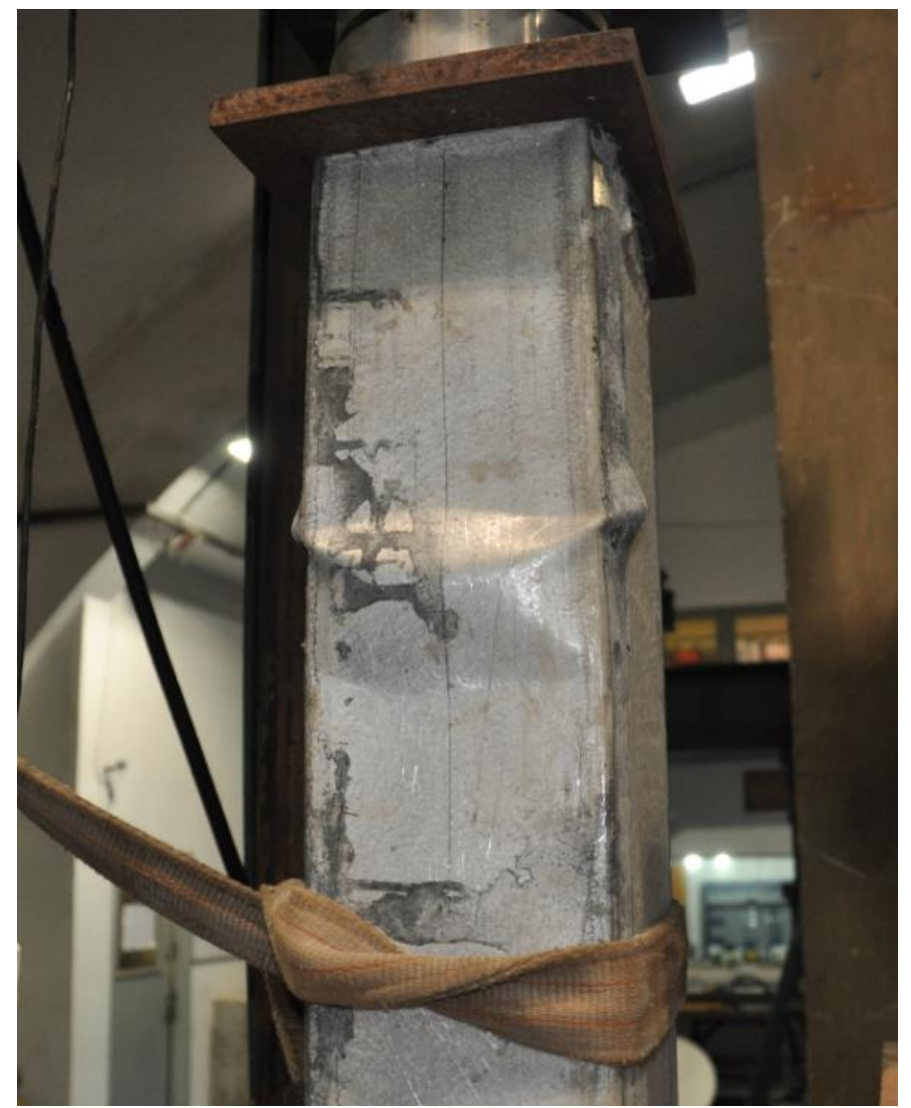

Figura 4.15 - Pilar 02 após o ensaio.

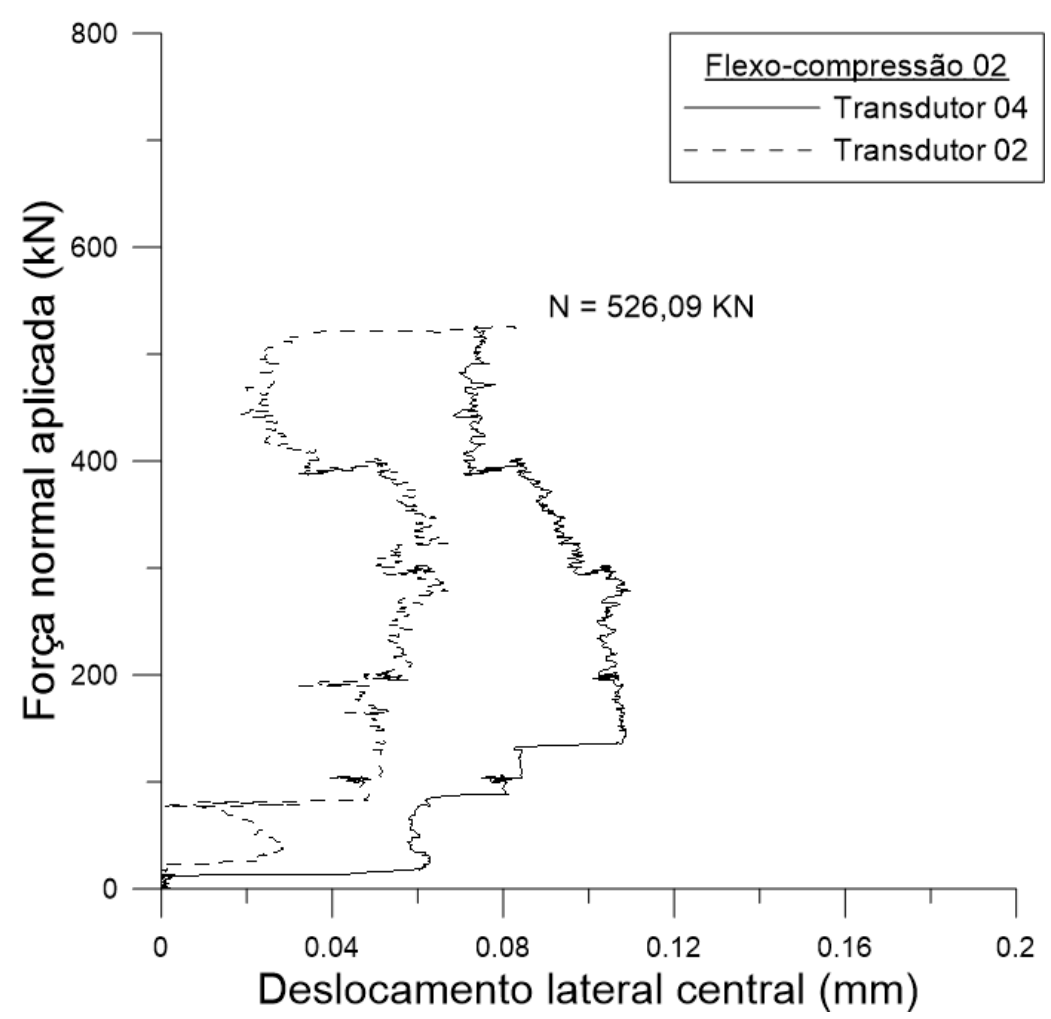

Figura 4.16 - Gráfico força normal aplicada x deslocamento lateral, TD02 e TD04, do Pilar 02. 


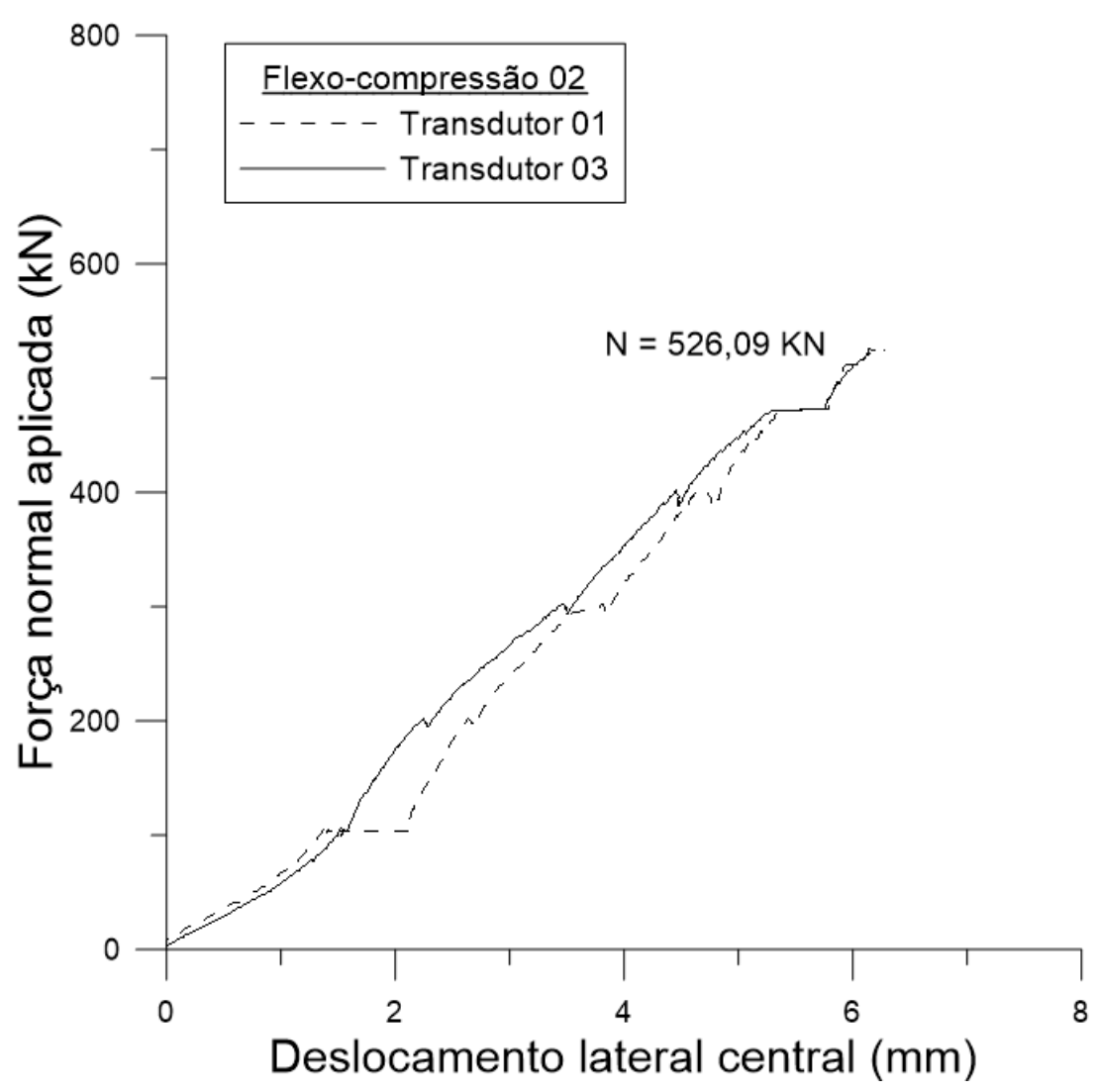

Figura 4.17- Gráfico força normal aplicada x deslocamento lateral, TD01 e TD03, do Pilar 02. 


\section{5 \\ Análise de resultados}

\section{1 .}

\section{Considerações iniciais}

Neste capítulo serão analisados os resultados experimentais apresentados no capítulo 4. Esses resultados serão comparados com os resultados teóricos e normativos, os quais foram calculados sem os coeficientes de ponderação para que pudessem ser comparados com os resultados experimentais.

É importante salientar que os métodos propostos pelas normas, e expostos no capítulo 2, não abrangem exatamente o tipo de seção transversal do pilar misto estudado nesse trabalho. Porém foram empregados neste item para efeito de comparação, de forma adaptada, como observa-se na memória de cálculo apresentada nos apêndices. De forma conservadora, todos os cálculos foram realizados desconsiderando os enrijecedores dos perfis.

Como informado no capítulo 2, para que um pilar misto seja dimensionado pela ABNT NBR 8800:2008 o fator de contribuição do aço deve estar entre 0,2 e 0,9. Para a seção estudada nesse trabalho o fator de contribuição, calculado pela eq. (2.1), considerando $f_{c k}=26,5 M P a$, é $\delta=0,259$. Logo pode-se usar a ABNT NBR 8800:2008 para o dimensionamento do pilar.

Vale ressaltar que quanto mais perto do limite inferior de 0,2 mais o pilar misto tem o comportamento parecido com o de um pilar de concreto. E se esse fator for menor que 0,2 o pilar deve ser dimensionado como um pilar de concreto armado adotando a ABNT NBR 6118:2014.

\section{2.}

\section{Colunas}

Como já fora mencionado, os resultados obtidos no ensaio da primeira coluna não devem ser aproveitados, uma vez que o apoio não estava em contato com toda a face da base da peça. Percebe-se, uma discrepância entre a normal resistente à plastificação dada pela eq. (2.2) desconsiderando-se os coeficientes de ponderação, igual a 988,97 kN, e a carga obtida pelo ensaio da Coluna 01, 457,5 kN. 
Corrigindo-se o erro do sistema de apoio foi possível executar o ensaio da segunda coluna, o qual forneceu carga de ruptura inferior ao valor calculado pelo método proposto na ABNT NBR 8800:2008. Enquanto a carga prevista era de $988,97 \mathrm{kN}$, a força normal aplicada que levou a Coluna 2 à ruptura foi de $800,0 \mathrm{kN}$. Na Tabela 6 os valores de força normal calculada, $N_{\text {teo }}$, e experimental, $N_{\text {exp }}$, são confrontados para cada uma das colunas.

Tabela 6 - Comparação entre a normal prevista e a normal experimental.

\begin{tabular}{|c|c|c|c|}
\hline Coluna & $N_{\text {teo }}(k N)$ & $N_{\text {exp }}(k N)$ & $N_{\text {exp }} / N_{\text {teo }}$ \\
\hline C01 & 988,97 & 457,5 & $46,3 \%$ \\
\hline C02 & 988,97 & 800,0 & $80,9 \%$ \\
\hline
\end{tabular}

\section{3.}

\section{Vigas}

O carregamento máximo previsto para as vigas foi calculado a partir de uma análise elasto-plástica, conforme é apresentado no apêndice A. De modo a facilitar as comparações com os momentos fletores calculados, conforme a análise de tensões e deformações e a ABNT NBR 8800:2008, o momento fletor aplicado nas vigas, apresentado no capítulo 4, será, neste capítulo, chamado de momento fletor experimental. Nele está sendo considerado, além do carregamento aplicado pelo atuador, o peso próprio da viga auxiliar e da peça estudada.

O momento fletor máximo calculado pela análise teórica, apresentado no apêndice A é igual a 26,31 kNm, e o obtido experimentalmente, 26,3 kNm para as duas vigas ensaiadas.

Conforme exposto no capítulo 4 , as vigas foram carregadas até que o deslocamento no centro do vão chegasse a $76 \mathrm{~mm}$, ou seja, vão/50. Pela equação da linha elástica, as cargas aplicadas nos ensaios na estrutura juntamente com o peso próprio e utilizando a rigidez efetiva à flexão calculada conforme a ABNT NBR 8800:2008, o deslocamento no vão central seria de 35,86 mm para a Viga 01 e 39,37 mm para a Viga 02. 


\section{4. \\ Pilares}

A partir dos ensaios das colunas e das vigas foi possível estimar os valores de força normal e momento fletor para os pilares mistos, sabendo-se que foram submetidos a um carregamento normal com excentricidade de $40 \mathrm{~mm}$. Considerando a força normal que levou a Coluna 02 a ruptura e a excentricidade de carga adotada, o momento fletor esperado no vão central corresponde a $32,0 \mathrm{kNm}$. A partir do momento fletor experimental determinou-se a força normal de compressão axial de $657,5 \mathrm{kN}$ para o pilar misto com excentricidade de carregamento.

Pela estimativa de carregamento aplicado determinado, seguindo as recomendações da ABNT NBR 8800:2008, para as colunas, 988,13 kN, o momento na seção do pilar com carregamento excêntrico de 0,04 m seria de 39,56 kNm. Já com o momento fletor resistente, calculado conforme apêndice A para as vigas, $26,32 \mathrm{kNm}$, a força normal aplicada no pilar que levaria a peça à ruína seria de 658 $\mathrm{kN}$, ver Tabela 7 .

Entre as forças normais, à compressão axial, estimadas por meio de ensaios, o valor estimado a partir dos ensaios das vigas foi a que mais se aproximou dos resultados obtidos nos ensaios dos dois pilares. Observa-se, também, que o valor calculado para os pilares a partir da teoria para a flexão das vigas e o valor estimado para os pilares a partir dos ensaios das vigas é praticamente o mesmo.

Observar, ainda na Tabela 7 , onde $N_{\text {vexp }}$ é a força normal de compressão axial calculada a partir dos ensaios das vigas e $N_{\text {exp }}$ é a força normal aplicada nos respectivos pilares até que ocorresse a ruína da peça. $N_{v t e o}$ é a força normal calculada no apêndice A para as vigas.

Tabela 7 - Comparação da estimativa pelos ensaios de flexão e pelo valor teórico à flexão, apêndice $\mathrm{A}$, com os ensaios de flexo-compressão.

\begin{tabular}{|c|c|c|c|c|c|}
\hline Pilar & $N_{\text {exp }}(k N)$ & $N_{\text {vexp }}(k N)$ & $N_{\text {exp }} / N_{\text {vexp }}$ & $N_{\text {vteo }}(k N)$ & $N_{\text {exp }} / N_{\text {vteo }}$ \\
\hline P01 & 613,7 & 657,5 & $93,3 \%$ & 658 & $93,3 \%$ \\
\hline P02 & 526,1 & 657,5 & $80,0 \%$ & 658 & $80,0 \%$ \\
\hline
\end{tabular}


No apêndice B é apresentado o cálculo seguindo uma análise de tensões e deformações para o caso do pilar misto com carregamento excêntrico estudado neste trabalho. A partir do que está apresentado neste apêndice determinou-se a força normal resistente de $384,85 \mathrm{kN}$.

No apêndice C é apresentado o cálculo seguindo as recomendações da ABNT NBR 8800:2008 e adaptando as fórmulas para a seção transversal estudada nessa pesquisa. Seguindo esse apêndice a força normal calculada foi de 453,4 kN.

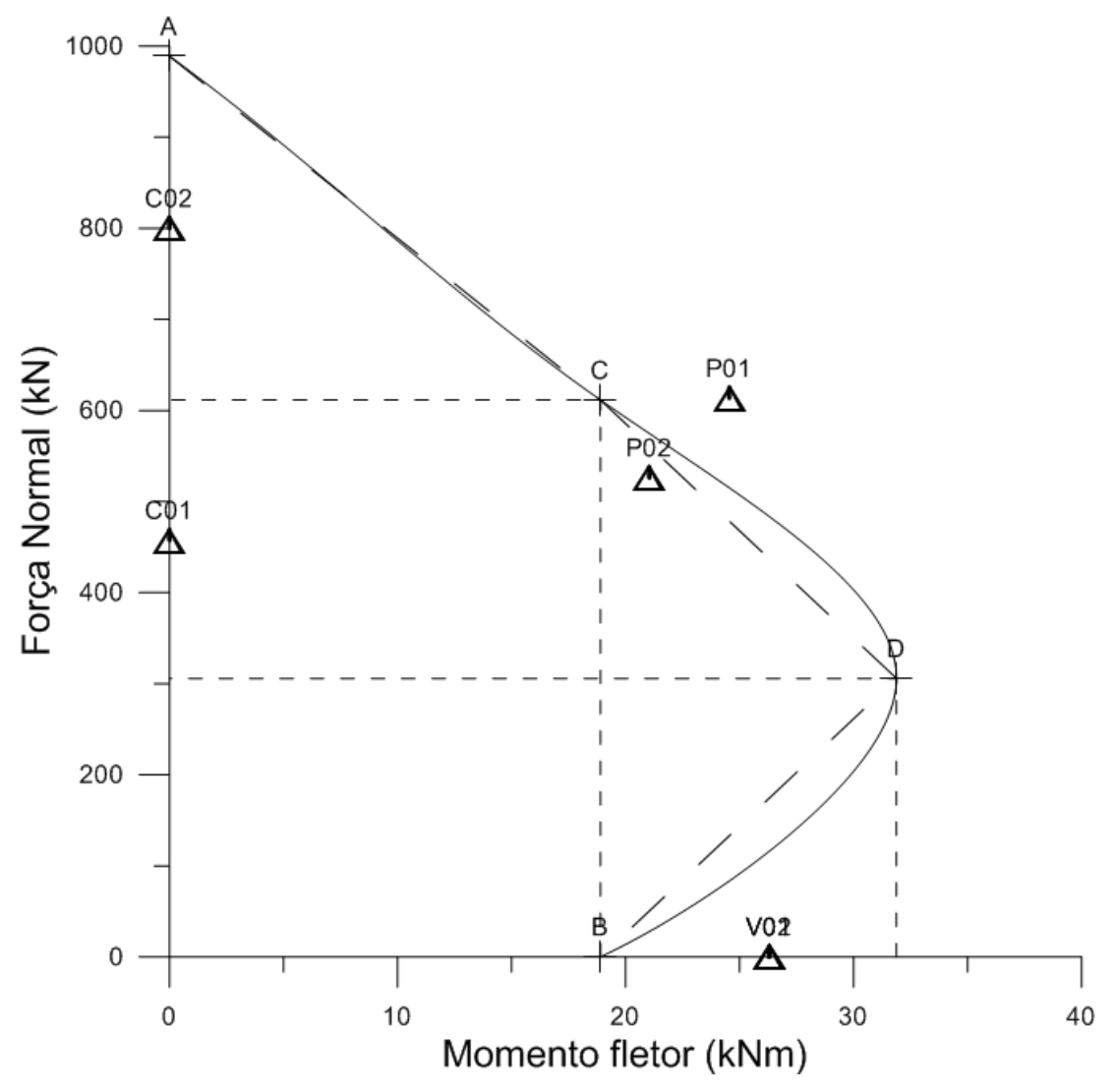

Figura 5.1- Curva de interação simplificada de acordo com o Euroode 4, 2004 e resultados experimentais representados por triângulos.

Seguindo as recomendações do Eurocode 4, 2004, montou-se a curva de interação simplificada, Figura 5.1, a partir dos valores calculados conforme o apêndice C. O ponto A tem coordenadas $\left(0, N_{p l, R d}\right)$, onde $N_{p l, R d}$ é a resistência plástica à compressão. $\mathrm{O}$ ponto $\mathrm{C}$ tem coordenadas $\left(M_{p l, R d}, N_{p m, R d}\right)$, sendo $N_{p m, R d}=0,85 f_{c d} A_{c}$ e $M_{p l, R d}$ o momento plástico resistente de projeto. $\mathrm{O}$ ponto $\mathrm{D}$, $\left(M_{m a ́ x, R d}, N_{p m, R d} / 2\right)$, onde $M_{m a ́ x, R d}$ é o momento plástico resistente máximo de projeto. E o ponto B, $\left(M_{p l, R d}, 0\right)$. 
Os valores de $N_{p l, R d}, M_{p l, R d}$ e $M_{m a ́ x, R d}$ foram calculados conforme preconiza a ABNT NBR 8800:2008, porém os valores foram calculados sem os coeficientes de ponderação para que fosse possível comparar com os resultados experimentais, ver procedimento adotado no apêndice C. Os pontos representados por triângulos apresentam os resultados experimentais, das colunas, vigas e pilares, apresentados no capítulo 4.

Como é possível observar na Figura 5.1 o valor experimental de força normal do Pilar 01 está na região considerada insegura, ou seja, fora do limite da curva de interação, o que demostra que o método preconizado pelo Eurocode 4, 2004, para plotar a curva, e pela ABNT NBR8800:2008, para os valores calculados, são conservadores.

Resistências para perfis com diferentes espessuras de chapa

$\diamond \diamond \diamond$ Calculados pela adaptação do método da NBR 8800:2008

+++ Calculados pela análise de tensões e deformações

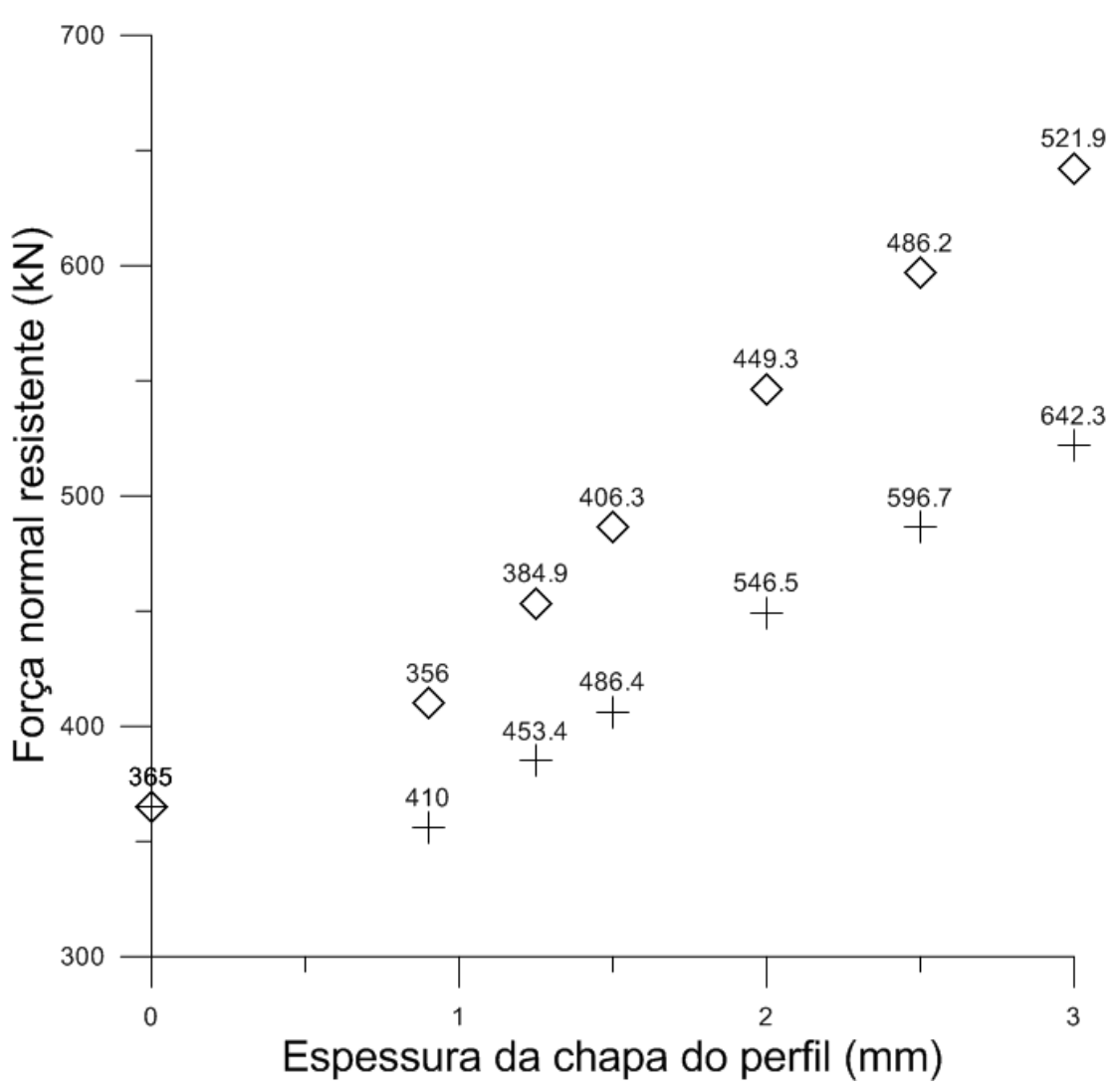

Figura 5.2 - Gráfico Força normal resistente versus espessura da chapa do perfil.

O gráfico apresentado na Figura 5.2 foi plotado a partir das forças normais resistentes calculadas para pilares mistos com a mesma seção estudada e com a 
mesma excentricidade de carga considerada, conforme apêndices B e C, alterandose a espessura da chapa do perfil, 0,90, 1,25, 1,50, 2,0, 2,5, e 3,0. Observa-se que os valores calculados pelo método adaptado a partir do proposto pela ABNT NBR 8800:2008, apêndice C, são superiores aos determinados pela análise de tensões e deformações, apêndice B.

A ABNT NBR6118:2014 não permite pilar de concreto armado com seção transversal de área inferior a $360 \mathrm{~cm}^{2}$. Porém, se o pilar fosse apenas de concreto armado, com a mesma armadura e a mesma seção transversal, a força normal resistente seria igual a $365 \mathrm{kN}$, com a mesma excentricidade de 0,04 m e considerando os coeficientes de ponderação das resistências igual a um. Esse estudo simples já indica que incluindo os perfis ocorre o aumento da capacidade de carregamento do pilar.

Considerando a tensão de escoamento do aço como $f_{y}=0,75 f_{y m e d}$, onde $f_{y m e d}$ é a média dos valores experimentais de tensão de escoamento apresentados na Tabela 5, o procedimento de cálculo exposto no apêndice $\mathrm{C}$ resulta numa força normal de $474 \mathrm{kN}$. Comparando a força normal calculada com a força máxima aplicada nos ensaios, uma tensão de escoamento maior que o limite de $410 \mathrm{MPa}$ aumentou em $6 \%$ a razão entre valor experimental e valor calculado para esse caso estudado. 


\section{6 \\ Considerações finais}

\section{1. Conclusões}

A combinação do aço com o concreto nas estruturas apresenta inúmeras vantagens em relação aos elementos somente de aço ou de concreto armado. Cabe ao projetista avaliar a melhor opção para cada projeto, e cabem às pesquisas o estudo de todos os parâmetros que possam interferir ou influenciar as recomendações das normas de maneira que se aproximem do comportamento real da estrutura, garantam a segurança e mantenham a viabilidade econômica.

É importante ressaltar a importância dos estudos experimentais que são capazes de reproduzir, elementos em escala real ou reduzida, o comportamento de determinado elemento ou material quando submetido às mesmas condições do lugar onde é aplicado. Portanto resultados experimentais fornecem dados importantes para o desenvolvimento de técnicas e materiais na engenharia.

Ao analisar separadamente o comportamento à flexão e o comportamento à compressão, fez-se possível avaliar de diferentes formas o comportamento do pilar misto submetido à flexo-compressão.

O objetivo de estudar e avaliar o comportamento de pilares mistos submetidos à compressão excêntrica foi alcançado, porém são necessários muitos outros estudos nessa linha de pesquisa.

Apesar de alguns gráficos, exibidos no capítulo 4, não apresentarem o comportamento esperado, devido ao deslizamento de transdutores ou por possíveis falhas na montagem e na execução dos ensaios, os valores máximos obtidos nos ensaios são coerentes com os teóricos calculados.

A partir da análise dos resultados, apresentada no capítulo 5, observa-se que um modelo elasto-plástico relativamente simples, como o apresentado no apêndice $\mathrm{B}$, pode representar adequadamente o comportamento de pilares mistos quanto à plastificação da seção, ainda que de maneira conservadora. 
Quanto aos perfis de aço, a diferença de seção transversal e os enrijecedores dos perfis não funcionaram como conectores entre aço e concreto, como era previsto. A região que o concreto não tem proteção nem dos perfis nem da armadura transversal foi a que se desprendeu tanto nos ensaios de compressão centrada, quanto nos com excentricidade de carregamento.

A partir da análise de resultados apresentada no capítulo 5, quando o aspecto analisado é a resistência, conclui-se que o pilar misto, nesse caso, tem vantagem significativa comparado ao pilar somente de concreto. Vigas de referência, de concreto armado, deveriam ter sido feitas e ensaiadas para verificar a real diferença entre o sistema misto e o concreto armado.

Da mesma forma, a tensão de escoamento do aço utilizado tem influência na resistência final do pilar, porém deve-se estudar melhor o comportamento desse material. Assim como, extensômetros posicionadas no aço, no concreto e nas armaduras poderiam ter dado melhor embasamento para as conclusões deste trabalho.

Conforme o que foi analisado neste trabalho, conclui-se que o tipo de seção analisada pode ser utilizada na prática de construção de pilares mistos. Contudo, são recomendadas análises mais aprofundadas em relação ao confinamento do concreto, uma vez que o desplacamento foi o ponto crítico dos ensaios.

\section{2 . \\ Sugestões para trabalhos futuros}

A seguir são propostos alguns trabalhos futuros com o objetivo de dar continuidade à linha de pesquisa deste trabalho, bem como complementar e aperfeiçoar o mesmo.

○ Estudar com mais afinco a interação entre o aço e o concreto e avaliar o uso ou não de conectores;

- Avaliar a contribuição do concreto, variando a sua resistência e analisando sua influência. Pode-se alterar a altura da seção transversal para estudar a influência da área de concreto na resistência do pilar;

○ Realizar uma investigação acerca da influência da variação da esbeltez do pilar misto para essa seção; 
- Estudar o mesmo pilar com a adição de battens ao longo do seu comprimento para tentar evitar o desplacamento do concreto e avaliar a influência deste recurso;

○ Investigar a contribuição das armaduras longitudinais, variando a área e as instrumentando nos ensaios;

○ Estudar as ligações para este tipo de pilar misto;

- Modelar em elementos finitos pilares com as mesmas características dos ensaiados neste trabalho. 


\section{7 \\ Referências bibliográficas}

ALVA, G. M. S. \& MALITE, M. Comportamento estrutural e dimensionamento de elementos mistos aço-concreto. Cadernos de Engenharia de Estruturas, pp. 51-84, 2005.

AMERICAN CONCRETE INSTITUTE. ACI 318 - Building code requirements for structural concrete. Detroit, 2014.

AMERICAN IRON STEEL INSTITUTE. AISI S100 - North American Specification for the Design of Cold-Formed Steel Structural Members. 2012.

American Institute of Steel Construction. AISC 360 Specification for Structural Steel Building, Chicago, USA, 2016.

ANDRADE, S. e VELLASCO, P. Comportamento e projeto de estruturas de aço. Elsevier: Editora PUC Rio. 408p. Rio de Janeiro, 2016.

ASSOCIAÇÃO BRASILEIRA DE NORMAS TÉCNICAS. NBR 5738: Procedimento para moldagem e cura de corpos de prova. 9 p. Rio de Janeiro, 2015 .

ASSOCIAÇÃO BRASILEIRA DE NORMAS TÉCNICAS. NBR 5739: Ensaios de compressão de corpos de prova cilíndricos de concreto. 9 p. Rio de Janeiro, 2007.

ASSOCIAÇÃO BRASILEIRA DE NORMAS TÉCNICAS. NBR 6118: Projeto de estruturas de concreto - Procedimento. 238 p. Rio de Janeiro, 2014.

ASSOCIAÇÃO BRASILEIRA DE NORMAS TÉCNICAS. NBR 6892-1: Materiais metálicos - Ensaio de tração à temperatura ambiente. 70 p. Rio de Janeiro, 2013 
ASSOCIAÇÃO BRASILEIRA DE NORMAS TÉCNICAS. NBR 7480: Aço destinado a armaduras para estruturas de concreto armado - Especificação. 7 p. Rio de Janeiro, 2007.

ASSOCIAÇÃO BRASILEIRA DE NORMAS TÉCNICAS. NBR 8800: Projeto de estruturas de aço e de estruturas mistas de aço e concreto de edifícios. 237 p. Rio de Janeiro, 2008.

ASSOCIAÇÃO BRASILEIRA DE NORMAS TÉCNICAS. NBR 12655: Concreto de cimento Portland - Preparo, controle e recebimento Procedimento. 23 p. Rio de Janeiro, 2006.

ASSOCIAÇÃO BRASILEIRA DE NORMAS TÉCNICAS. NBR 14762: Dimensionamento de estruturas de aço constituídas por perfis formados a frio. 87 p. Rio de Janeiro, 2010.

ASSOCIATION CANADIAN STANDARDS. CAN/CSA-S16: Limit states design of steel structure. 174 p. Ontario, 2010.

BIANCHI, F. R. Análise do comportamento dos pilares mistos considerando a utilização de conectores de cisalhamento. Universidade Federal do Espírito Santo. 163 p. Vitória. 2002.

CANADIAN INSTITUTE OF STEEL CONSTRUCTION. Handbook of steel construction. Ontario, 2006.

CARVAlHO, R. E PINHEIRO, L. Cálculo e Detalhamento de Estruturas Usuais de Concreto Armado. Vol. 2. 2013.

CHIEN, E. Y. L. \& RITCHIE, J.K. Design and Construction of Composite floor systems. Canadian Institute of Steel Construction. 323 p. Ontario, 1984.

DAltro, A. M. Análise Teórico-Experimental de Treliças Leves de Perfis de Chapa Dobrada. Pontifícia Universidade Católica do Rio de Janeiro. 90 p. Rio de janeiro. 2016. 
Eurocode 4. EN 1994, Design of composite steel and concrete structures Part 1.1 General rules and rules for buildings, Brussels, CEN-European Committee for Standardization. 118 p. 2004.

FABRIZZI, M. D. A. Contribuição para o projeto e dimensionamento de edifícios de múltiplos andares com elementos estruturais mistos aço-concreto. 233 p. Universidade de São Paulo. São Carlos. 2007.

FIGUEIREDO, L. M. B. Projeto e construção de pilares mistos aço-concreto. Universidade de São Paulo. 160 p. São Carlos. 1998.

FIGUEIREDO, Matheus. J. E MOLITERNO, Rafael. R. Estudo de pilares mistos com ênfase na resistência à flexão usando-se perfis de aço de alta resistência. Projeto Final de Graduação. Pontifícia Universidade Católica. 40 p. Rio de Janeiro, 2016.

GIAKOUMELIS, G. \& LAM, D. Axial capacity of circular concrete-filled tube columns. Journal of Constructional Steel Research, pp. 1049-1068, 2004.

KENNEDY, S. J. \& MacGREGOR, J. G. End connection effects on the strength of concrete filled HSS beam columns. Structural Engineering Report n. 115. University of Alberta. Alberta, 1984.

MALITE, M. Sobre o cálculo de vigas mistas aço-concreto: ênfase em edifícios. Universidade de São Paulo. 152 p. São Carlos. 1990.

MIRZA, S. A. Parametric Study of Composite Column Strength Variability. Lakehead University. Steel Research 14, pp. 121-137,1989.

OliveirA, W. L. A. D.; EL DEBS, A. L. H. D. C. Estudo do Efeito de Confinamento do Concreto em PMP curtos. Universidade de São Paulo. São Carlos, p. 39-53. 2009.

PAIVA, João. D. G. E CARVALHO, Daniel. S. Estudo teórico experimental de colunas mistas com aço de alta resistência. Projeto Final de Graduação. Pontifícia Universidade Católica do Rio de Janeiro. 28 p. Rio de Janeiro, 2016. 
THE STEEL CONSTRUCTION INSTITUTE. Steel Designers' Manual. 6th Edition. 1321 p. 2003. 


\section{8 \\ Apêndice A}

Este apêndice apresenta de forma resumida a memória de cálculo referente aos valores teóricos para as vigas. Vale ressaltar que este procedimento de cálculo foi realizado de forma iterativa e que os cálculos foram feitos sem os coeficientes de ponderação para efeito comparativo.

Para a determinação da altura da linha neutra, consideraram-se as hipóteses de deformação e tensão, caracterizando uma análise elasto-plástica da seção. Para o diagrama de deformação foi considerada a deformação específica de encurtamento do concreto na ruptura, $\varepsilon_{c}=3,5 \%_{0}$.

Pode-se definir as deformações nos elementos restantes e a altura da linha neutra, $\mathrm{x}$, através da semelhança de triângulos de forma que a força do concreto, $\mathrm{Fc}$, calculada pelo equilíbrio de forças e a calculada pela tensão do concreto seja a mesma, ver Figura A. 1.

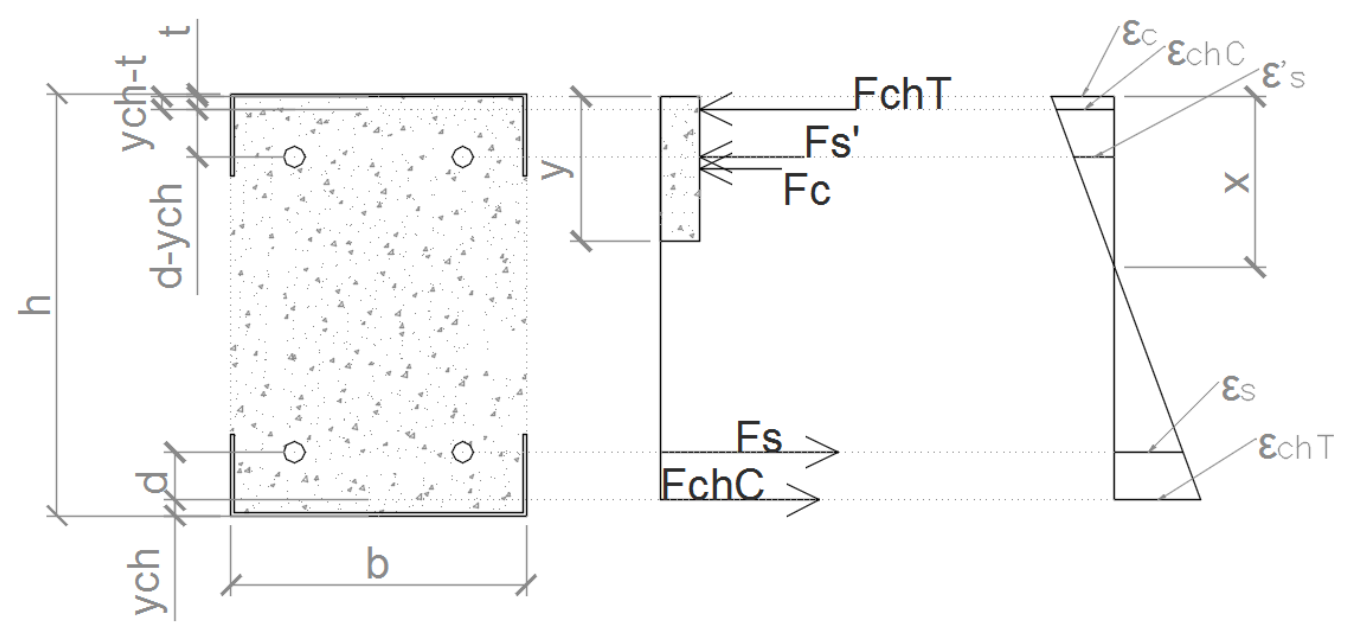

Figura A. 1 - Forças internas e deformações da seção submetida à flexão.

O módulo de elasticidade da chapa fina de aço foi considerado como $E=$ $200 \mathrm{Gpa}$, assim como o módulo das barras longitudinais, de aço - CA50. O $f_{c k}$ foi tomado como 26,5 MPa. As dimensões da seção transversal estão apresentadas na Figura 3.2 e foram consideradas sem enrijecedores como apresentado na Figura 3.3 (a). 
Admite-se que a distribuição de tensões do concreto seja feita de acordo com o diagrama parábola-retângulo, mas permite-se a substituição do diagrama parábola-retângulo por um retângulo de altura $y=0,8 x$.

$$
\begin{gathered}
\varepsilon_{s}=\frac{\varepsilon_{c}}{x}(h-t-x-d) \\
f_{s}=\varepsilon_{s} E
\end{gathered}
$$

Como $x \geq d$, então:

$$
\begin{gathered}
\varepsilon^{\prime}{ }_{s}=\left(1-\frac{d-t}{x}\right) \varepsilon_{c} \\
f^{\prime}{ }_{s}=\varepsilon^{\prime}{ }_{s} E
\end{gathered}
$$

De forma análoga calculou-se as deformações específicas dos perfis de aço, comprimido e tracionado conforme eq. (A.7) e eq. (A.5) respectivamente. Onde o índice chC indica o perfil comprimido e o índice chT o perfil tracionado, e $y_{c h}$ é a distância, em mm, da face da peça ao centroide do perfil de aço, conforme a eq. (A.9). Onde a é a altura da alma do perfil, $38,75 \mathrm{~mm}$.

$$
\begin{gathered}
\varepsilon_{c h T}=\frac{\varepsilon_{s}\left(h-t-x-y_{c h}\right)}{h-t-d-x} \\
f_{c h T}=\varepsilon_{c h T} E \\
\varepsilon_{c h c}=\left(1+\frac{d-y_{c h}}{x}\right) \varepsilon_{c} \\
f_{c h c}=\varepsilon_{c h c} E \\
y_{c h}=\frac{(b-2 t) t^{2}+2 t a^{2}}{2 A_{c h}}=7,38 \mathrm{~mm}
\end{gathered}
$$

De acordo com o anexo F da ABNT NBR 8800:2008, sempre que um elemento de aço for axialmente comprimido deve-se verificar a relação entre largura e espessura. O valor definido pelo Grupo 1 da tabela F.1 da mesma norma é o valor limite para essa relação. Caso esse valor seja ultrapassado, deve-se fazer uma redução da largura do elemento, indicado na seção F.3 da norma e a seguir.

Verificação da relação largura e espessura, onde: $c_{a}=0,34$ e $\sigma=f_{c h c}$.

$$
\begin{gathered}
\frac{b}{t}=\frac{140}{1,25}=112 \\
\left(\frac{b}{t}\right)_{\text {lim }}=1,40 * \sqrt{\frac{E}{f_{y}}}=30,92 \\
\frac{b}{t}>\left(\frac{b}{t}\right)_{\text {lim }}
\end{gathered}
$$


Cálculo da largura efetiva, $\mathrm{b}_{\mathrm{ef}}$ :

$$
\begin{gathered}
b_{e f}=1,92 * t * \sqrt{\frac{E}{\sigma}} *\left[1-\frac{c_{a}}{\frac{b}{t}} * \sqrt{\frac{E}{\sigma}}\right] \leq b \\
b_{e f}=39,85 \mathrm{~mm}
\end{gathered}
$$

Com esse novo valor de largura tem-se uma redução da área do elemento comprimido, $A_{c h c}=t b_{e f}+2 t(a-t)=143,56 \mathrm{~mm}^{2}$ e pode-se fazer o equilíbrio de forças e determinar a força no concreto.

$$
\begin{gathered}
\sum F_{x}=0 \\
F_{c}=-F_{c h c}-F_{s}^{\prime}+F_{s}+F_{c h T} \\
F_{c}=0,85 f_{c k}\left(y b-A_{s}-A^{\prime}{ }_{s}-A_{c h}-A_{c h c}\right)
\end{gathered}
$$

Com todas as forças que atuam na seção e altura da linha neutra definidas, pode-se definir o valor do momento fletor resistente da peça:

$$
\begin{gathered}
M_{r}=\sum F * d_{L . N .} \\
M_{r}=F_{c}\left(\frac{h}{2}-t-\frac{y}{2}\right)+F_{s}^{\prime}\left(\frac{h}{2}-d\right)+F_{c h C}\left(\frac{h}{2}-y_{c h}\right)
\end{gathered}
$$

Determina-se, portanto, a altura da linha neutra $\mathrm{x}$, igual a $83,11 \mathrm{~mm}$ e o momento fletor resistente da peça, $M_{r}=26,32 \mathrm{kNm}$. 


\section{9}

\section{Apêndice B}

Assim como o apêndice anterior, este apresenta de forma resumida a memória de cálculo referente aos valores teóricos para os pilares. Vale ressaltar que estes cálculos foram realizados de forma iterativa e que os cálculos foram feitos sem os coeficientes de ponderação para que fosse possível fazer uma comparação com os resultados experimentais.

De forma semelhante ao apêndice A considerou-se a deformação específica do concreto igual a 3,5 por mil e usou-se da semelhança de triângulos da análise de tensões e deformações para determinar a altura da linha neutra e a força normal atuante na seção a uma excentricidade $e=40 \mathrm{~mm}$.

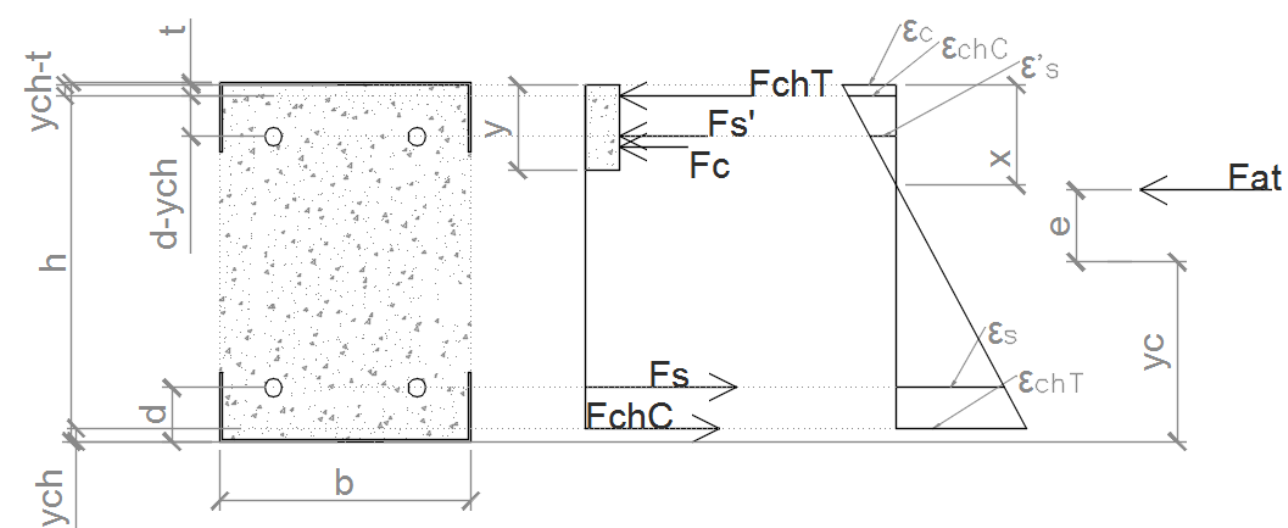

Figura B. 1 - Forças internas e externa da seção submetida à flexocompressão.

Os cálculos das deformações específicas podem ser realizados conforme as eqs. (A.1), (A.3), (A.5) e (A.7) e as tensões conforme as eqs. (A.2), (A.4), (A.6) e (A.8) do apêndice A. A largura efetiva segue o mesmo princípio apresentado no apêndice anterior e tem valor de $40,61 \mathrm{~mm}$, portanto a área do perfil comprimido deve ser substituída por 144,51 mm².

$$
\begin{gathered}
\sum F_{x}=0 \\
F_{a t}=F_{c}+F_{s}^{\prime}+F_{c h C}-F_{s}-F_{c h T}
\end{gathered}
$$


Realizando o equilíbrio de forças, onde $F_{c}$ é calculado conforme a eq. (A.17) e as demais forças são dadas pela multiplicação da tensão e sua respectiva área. A Figura B. 1 indica as dimensões, as forças e o diagrama com as deformações da seção com carregamento excêntrico.

$$
y_{t}=\frac{A_{c h} y_{c h}+A_{s} d}{A_{c h}+A_{s}}
$$

Fazendo-se o somatório dos momentos em relação ao centroide tracionado, $y_{t}$, calculado conforme eq. (B.3), igual a zero, a excentricidade, $e$, deve dar igual a $40 \mathrm{~mm}$ para que defina-se a altura da linha neutra, $\mathrm{x}$, e a força normal atuante.

$$
\begin{gathered}
\sum M=0 \\
F_{a t}\left(e+\frac{h}{2}+y_{t}\right)=F_{c}\left(h+t-\frac{y}{2}-y_{t}\right)+F_{s}^{\prime}\left(h-d-y_{t}\right)+F_{c h c}\left(h-y_{c h}-y_{t}\right)
\end{gathered}
$$

Portanto, obtém-se os valores de: $x=57,10 \mathrm{~mm}$ e $F_{a t}=384,85 \mathrm{kN}$. 


\section{Apêndice C}

Este apêndice apresenta algumas considerações sobre o dimensionamento de pilares submetidos à flexo-compressão conforme a ABNT NBR 8800:2008 e sugere algumas adaptações para a seção estudada, a qual não se encaixa nos tipos de seções abordados pela norma em questão.

Para calcular os momentos fletores de plastificação é necessário calcular os módulos de resistência plásticos para a seção do perfil, para a seção da armadura, para a seção de concreto considerado não fissurado e outros três módulos que correspondem a esses materiais considerando apenas as partes que estão na região de duas vezes a altura da linha neutra plástica.

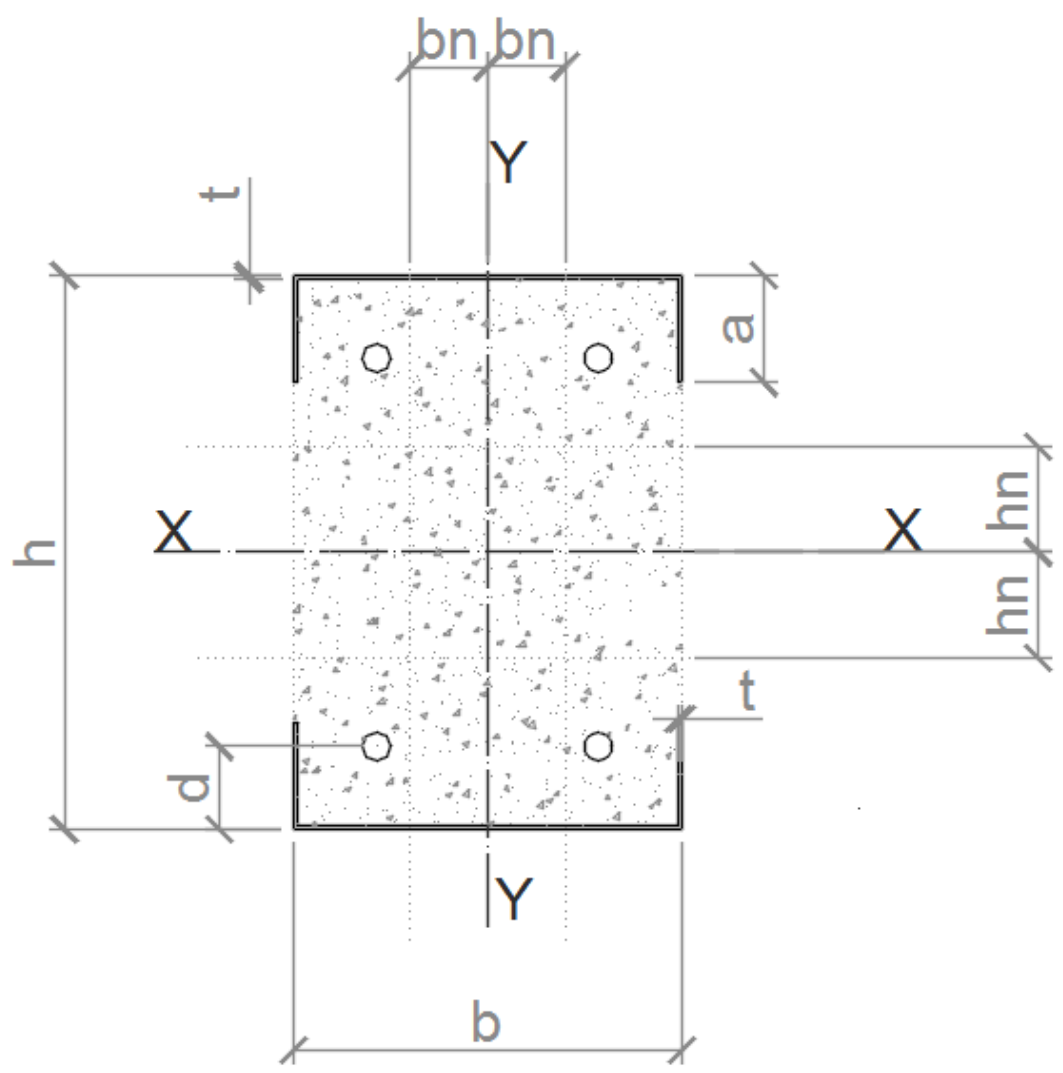

Figura C. 1 - Seção transversal e dimensões consideradas. 
Considerando a seção da Figura C. 1 para avaliar a altura da linha neutra plástica, $h_{n}$, é necessário avaliar as três regiões possíveis na qual a linha neutra estará posicionada.

a) Se a linha neutra plástica estiver na alma do perfil de aço e acima da armadura,

$$
\begin{aligned}
h_{n}>\frac{h}{2}-d & \\
& h_{n}=\frac{A_{c} f_{c d 1}-4 t\left(a-\frac{h}{2}\right)\left(2 f_{y d}-f_{c d 1}\right)-A_{s n}\left(2 f_{s d}-f_{c d 1}\right)}{2 b_{c} f_{c d 1}+4 t\left(2 f_{y d}-f_{c d 1}\right)}
\end{aligned}
$$

b) Se a linha neutra plástica estiver na alma do perfil de aço e abaixo da armadura, $\frac{h}{2}-a<h_{n}<\frac{h}{2}-d:$

$$
h_{n}=\frac{A_{c} f_{c d 1}-4 t\left(a-\frac{h}{2}\right)\left(2 f_{y d}-f_{c d 1}\right)}{2 b_{c} f_{c d 1}+4 t\left(2 f_{y d}-f_{c d 1}\right)}
$$

c) Se a linha neutra plástica estiver fora do perfil de aço, $h_{n}<\frac{h}{2}-a$ :

$$
h_{n}=\frac{A_{c} f_{c d 1}}{2 b_{c} f_{c d 1}+4 t\left(2 f_{y d}-f_{c d 1}\right)}
$$

A partir da altura da linha neutra plástica, $h_{n}$, é possível calcular $Z_{a n}, Z_{c n}$ e $Z_{s n}$ que correspondem ao módulo de resistência plástico da seção dentro da região de altura $2 h_{n}$ para cada um dos materiais, sendo $a$ correspondente ao aço dos perfis, $c$ ao concreto e $s$ ás barras da armadura longitudinal.

De forma análoga, considerando o eixo y da Figura C. 1 para avaliar a altura da linha neutra plástica, $b_{n}$, é necessário avaliar as regiões possíveis na qual a linha neutra pode estar posicionada.

a) Se a linha neutra plástica estiver acima da armadura, $b_{n}>\frac{b}{2}-d$ :

$$
b_{n}=\frac{A_{c} f_{c d 1}+4 t\left(\frac{b}{2}\right)\left(2 f_{y d}-f_{c d 1}\right)-A_{s n}\left(2 f_{s d}-f_{c d 1}\right)}{2 h_{c} f_{c d 1}+8 t\left(2 f_{y d}-f_{c d 1}\right)}
$$

b) Se a linha neutra plástica estiver abaixo da armadura, $b_{n}<\frac{b}{2}-d$ :

$$
b_{n}=\frac{A_{c} f_{c d 1}+4 t\left(\frac{b}{2}\right)\left(2 f_{y d}-f_{c d 1}\right)}{2 h_{c} f_{c d 1}+8 t\left(2 f_{y d}-f_{c d 1}\right)}
$$


Determina-se então, $Z_{a n}, Z_{c n}$ e $Z_{s n}$ que correspondem ao módulo de resistência plástico da seção dentro da região de altura $2 b_{n}$ para casa um dos materiais.

Calculados os módulos de resistência plásticos é possível calcular o momento plástico resistente conforme a eq. (C.6) e o momento fletor máximo resistente de plastificação conforme a eq. (C.7), fornecidas pela ABNT NBR 8800:2008 para cada um dos eixos da seção transversal.

$$
\begin{gathered}
M_{p l R d}=f_{y d}\left(Z_{a}-Z_{a n}\right)+0,5 f_{c d 1}\left(Z_{c}-Z_{c n}\right)+f_{s d}\left(Z_{s}-Z_{s n}\right) \\
M_{\text {maxplRd }}=f_{y d} Z_{a}+0,5 f_{c d 1} Z_{c}+f_{s d} Z_{s}
\end{gathered}
$$

Com esses dados utiliza-se o modelo de cálculo II, apresentado no item P.5.3 da mesma norma, para verificar os efeitos da força axial de compressão, $N_{S d} \leq$ $N_{R d}$, e dos momentos fletores, eq. (C.8).

$$
\frac{M_{x t o t s d}}{\mu_{x} M_{c x}}=\frac{M_{y t o t s d}}{\mu_{y} M_{c y}} \leq 1,0
$$

Onde $\mu_{x}$ é um coeficiente calculado pela eq. (C.9) para $N_{S d} \geq N_{c}$; pela eq. (C.10) para $N_{c} / 2 \leq N_{S d}<N_{c}$; e conforme a eq. (C.11) para $0 \leq N_{S d}<N_{c} / 2$. E $M_{\text {xtotsd }}$ é o momento fletor solicitante de cálculo total em relação ao eixo x, determinado pela eq. (C.12).

$$
\begin{gathered}
\mu_{x}=1-\frac{N_{S d}-N_{p l c R d}}{N_{p l R d}-N_{p l c R d}} \\
\mu_{x}=\left(1-\frac{M_{d x}}{M_{c x}}\right)\left(\frac{2 N_{S d}}{N_{p l R d}}-1\right)+\frac{M_{d x}}{M_{c x}} \\
\mu_{x}=1+\frac{2 N_{S d}}{N_{p l R d}}\left(\frac{M_{d x}}{M_{c x}}-1\right) \\
M_{x t o t S d}=M_{x S d}+M_{x i S d}
\end{gathered}
$$

Onde $M_{d x}$ é considerado como na eq. (C.13), e para determinar o momento solicitante de cálculo, $M_{x S d}$, utilizou-se a excentricidade de $40 \mathrm{~mm}$ e a carga $N_{S d}$, que neste caso representa a força normal máxima que deseja-se determinar, eq. (C.14).

$$
\begin{gathered}
M_{d x}=0,8 M_{\text {maxplRd }} \\
M_{x S d}=N_{S d} e_{y}
\end{gathered}
$$




$$
\begin{gathered}
M_{x i S d}=\frac{N_{S d} L_{x}}{150\left(1-\frac{N_{S d}}{N_{e 2 x}}\right)} \\
N_{e 2 x}=\frac{\pi^{2}(E I)_{e x}}{L_{x}}
\end{gathered}
$$

$M_{x i s d}$ representa o momento devido às imperfeições ao longo do pilar em relação ao eixo x, conforme eq. (C.15). Na eq. (C.16), $(E I)_{\text {ex }}$ representa a rigidez efetiva à flexão calculada conforme a eq. (2.7). Caso $M_{d x}$ seja menor que $M_{c x}$, então $M_{d x}$ deve ser tomado igual a $M_{c x}$.

Como neste trabalho a intenção era determinar a força normal aplicada com uma excentricidade de $40 \mathrm{~mm}$ montou-se uma iteração. Alterou-se a força normal, até que a eq. (C.8) fosse igual a 1. 